\title{
Canada's Response to \\ the 1968 Soviet Invasion of Czechoslovakia: \\ An Assessment of the Trudeau Government's \\ First International Crisis
}

by

Angus McCabe

A thesis submitted to the Faculty of Graduate and Postdoctoral Affairs

in partial fulfillment of the requirements for the degree of

\author{
Master of Arts \\ in \\ History \\ Carleton University \\ Ottawa, Ontario \\ (C) 2019 \\ Angus McCabe
}




\begin{abstract}
The new government of Pierre Trudeau was faced with an international crisis when, on 20 August 1968, the Soviet Union invaded Czechoslovakia. This study is the first full account of the Canadian government's response based on an examination of the archival records of the Departments of External Affairs, National Defence, Manpower and Immigration, and the Privy Council Office. Underlying the government's reaction were differences of opinion about Canada's approach to the Cold War, its role at the United Nations and in NATO, the utility of the Department of External Affairs, and decisions about refugees. There was a delusory quality to each of these perspectives. In the end, an inexperienced government failed to heed some of the more competent advice it received concerning how best to meet Canada's interests during the crisis. National interest was an understandable objective, but in this case, it was pursued at Czechoslovakia's expense.
\end{abstract}




\section{Acknowledgements}

As anyone in my position would attest, meaningful work with Professor Norman Hillmer brings with it the added gift of friendship. The quality of his teaching, mentorship, and advice is, I suspect, the stuff of ages. I am grateful for the privilege of his guidance and comradeship. Graduate Administrator Joan White works kindly and tirelessly behind the scenes of Carleton University's Department of History. She has been an enormous, friendly help. Thank you to my wife and children - for your life with me, and, in this case, living with my decision to undertake this work when I did. I thank my parents, who gave me the wonder that inspires the work. 
Table of Contents

$\begin{array}{lll}\text { Abstract } & \text { ii }\end{array}$

Acknowledgements

Table of Contents iv

Introduction 1

Chapter One: The Political Interest 10

$\begin{array}{ll}\text { The Lead-up } & 10\end{array}$

$\begin{array}{ll}\text { The Invasion } & 17\end{array}$

$\begin{array}{ll}\text { Sharp's Initial Reaction } & 19\end{array}$

A More "Vigorous" Response 24

Centre Stage at the UN 28

Trudeau, Cadieux, NATO, and Détente 50

Détente versus Liberalization $\quad 59$

Artists and Espionage $\quad 65$

Was the DEA "Necessary?" 69

$\begin{array}{ll}\text { Czechoslovakian Canadians } & 74\end{array}$

Sharp's Promise $\quad 76$

$\begin{array}{ll}\text { Chapter Two: The Economic Interest } & 77\end{array}$

$\begin{array}{ll}\text { An Emerging Refugee Crisis? } & 78\end{array}$

$\begin{array}{ll}\text { Cadieux Weighs In } & 87\end{array}$

Talent Team and "a Good Investment" 95

$\begin{array}{ll}\text { Sweetening the Deal } & 110\end{array}$

"This is a tough one" 113

"Discriminatory Shoppers": Ending the Programme 114 
Conclusion

121

Bibliography

130 
Introduction

Late in the evening of 20 August 1968, Soviet and other Warsaw Pact tanks rolled into Czechoslovakia. Within hours, Russian soldiers had arrested the country's leader, Alexander Dubcek, and taken him away to an undisclosed location. ${ }^{1}$ The early morning reports of Canada's senior diplomat in Prague, Chargé d'affaires Charles Cole, painted a vivid picture of a city waking up to uninvited occupation. Though the "occupation of the city seem[ed] to be proceeding peacefully," Cole noticed "many Czechoslovaks in the streets unashamedly crying." ${ }^{2}$ TASS, Russia's official news agency, was already stating on the radio what the Soviets would insist throughout the crisis: that the "troops had come at the request of Czechoslovak officials."3

The Soviet Union and four of its allies had invaded Czechoslovakia, itself a Warsaw Pact nation but one in the midst of liberalizing reforms no longer to be tolerated by the Kremlin. What Canada or any other nation could do was limited. The West was not about to let this trigger the unthinkable, nor derail indefinitely the promise of détente. Still, the "Czech Situation" needed to be managed. ${ }^{4}$ A new government in Canada was met with its first East-West foreign policy challenge.

${ }^{1}$ The invasion began around 11:00 p.m. Prague is six hours ahead of Ottawa, but this time difference also depends on various adjustments for Daylight Savings Time. On that day, noon Prague time was 7:00 a.m. Ottawa time - a five-hour difference. See LAC, RG 2, Series A-5-a, Vol. 6338, Cabinet minutes, 21 August 1968. 2-3; LAC, RG 25, Vol. 8907, File 20, Part 4. Message (747), Cole to External Affairs, 21 August 1968; Vincent Buist, "Gunfire, phone wires ripped out and a cold meal: How Russian soldiers hustled a handcuffed Dubcek out of Prague," The Globe and Mail, 29 August 1968, A1; "Dubcek reported free, may get his job back; Czechs say he's on way to Prague," Toronto Star, 24 August 1968, A1, A4; "Soviet troops get tougher; Czechs hold one-hour strike," Toronto Star, 23 August 1968, A1.

2 LAC, RG 25, Vol. 8907, File 20, Part 4. Message (750), Cole to External Affairs, 21 August 1968; LAC, RG 25, Vol. 8907, File 20, Part 4. Message (759), Cole to External Affairs, 21 August 1968.

${ }^{3}$ LAC, RG 25, Vol. 8907, File 20, Part 4. Message (750), Cole to External Affairs, 21 August 1968.

${ }^{4}$ In Canadian government agendas, memoranda, and communiqués produced during the crisis, the Soviet invasion of Czechoslovakia was typically referred to as the "Czech Situation," the "Czechoslovak Situation," or the "Situation in Czechoslovakia." See, for example, LAC, RG 25, Vol. 8907, File 20, Part 4. Message (No. S-888), J.G.H. Halstead to Prague, 21 August 1968. 
An analysis of government documents from the time suggests that the invasion was an issue that had substantial resonance in Ottawa that summer. At times it topped the agenda of the Federal cabinet. This same sense of urgency can be seen in the related documents generated by Canada's civil service at home, from embassies abroad, and from the country's permanent delegations at the UN and NATO. It remained a significant concern for immigration officials through to the end of the Czechoslovakian refugee programme in January, 1969, and the months following its termination. A canvass of Canadian newspapers from the period suggests a similar pre-occupation in the media.

Yet in the half-century since the invasion, historians looking back at the first year of the Trudeau government have produced little more than brief summaries of Canada's involvement in the crisis. The invasion of Czechoslovakia is seen by most as a footnote in Canadian foreign policy. This study is the first full reconstruction of the Canadian government's response to the crisis from start to finish. It explores the government's toplevel decision-making during the crisis, Canada's activity at the UN, and the related work of government departments. It is based on an examination of the archival records of the Department of External Affairs, the Department of Manpower and Immigration, the Department of National Defence, and the Privy Council Office. ${ }^{5}$ This analysis is supplemented by a review of the issue's treatment by two, more nationally-oriented, metropolitan newspapers of record, the Globe and Mail and the Toronto Star.

\footnotetext{
${ }^{5}$ The Department of National Defence files in question contain the records of Canada's activity at the UN in connection to the crisis. Note that these same records can be found in the Department of External Affairs fonds. See LAC, RG 24-B-2, Vol. 21594, File S-2-5080-7. "United Nations-Czechoslovakia-Crisis," August 21-November 8, 1968; LAC, RG 25, Vol. 8907, File 20, Parts 3-10; Vol. 8908, File 20, Parts 1118. "Czech-1-3-USSR, Czech-political affairs," August-October, 1968.
} 
The work here does not set out to disprove the consensus that historians have usually arrived at about Canada's crisis response that summer. Nor does it take significant issue with the thesis of the most comprehensive work thus far produced on the subject: Laura Madokoro’s 2009 Refuge article “Good Material: Canada and the Prague Spring Refugees." Madokoro's work is confined to the refugee aspect of the Czechoslovakian crisis. ${ }^{6}$ This study, for the first time, casts the net wider on the subject. It also endeavours to complement the ongoing work undertaken in recent years by Brendan Kelly related to then-Under-Secretary of State for External Affairs Marcel Cadieux. ${ }^{7}$

No historian to date has taken on the full subject matter in any greater detail, perhaps in part because of the agreement that Canada's response, like the rest of the West's, was a forgone conclusion. J.L. Granatstein began the historiography with his article on "External Affairs and Defence" for the 1968 Canadian Annual Review (CAR). His twopage section on the invasion was, for five decades, the most in-depth review of Canada's overall response to the crisis. ${ }^{8}$ An account of similar length to his is also contained in the third volume of the Department of External Affair's official history, published in $2017 .{ }^{9}$ Bruce Thordarson's 1972 Trudeau and Foreign Policy: A Study in Decision-making, refers to the crisis briefly. Peter Dobell's Canada's Search for New Roles, from that same year, does not mention it at all. ${ }^{10}$

6 Laura Madokoro, "Good Material: Canada and the Prague Spring Refugees," Refuge 26 no. 1 (March, 2009): 161-171.

7 Kelly Brendan, "The politician and the civil servant: Pierre Trudeau, Marcel Cadieux, and the DEA, 1968-1970," International Journal 2017, vol.72 (I): 5-27.

8 J.L. Granatstein, "External Affairs and Defence," in Canadian Annual Review, 1968, ed. John Saywell, (Toronto: University of Toronto Press, 1969), 240-242; 217; 220; 217-282.

9 See John Hilliker, Greg Donaghy, and Mary Halloran. Canada's Department of External Affairs, Volume 3: Innovation and Adaptation, 1968-1984 (Toronto: University of Toronto Press, 2017), 39-42.

${ }^{10}$ See Bruce Thordarson, Trudeau and Foreign Policy: A Study in Decision-making. (Toronto: Oxford University Press, 1972), 66; Peter Dobell, Canada's Search for New Roles: Foreign Policy in the Trudeau Era (London: Oxford University Press, 1972). 
Comprehensive histories of Trudeau's foreign policy, including Granatstein and Robert Bothwell's 1990 Pirouette and Bothwell's 2007 Alliance and Illusion: Canada and the World, 1945-1984, reinforce the thesis that the Canadian government "duly protested" the Soviet crushing of the Prague Spring, that the crisis did not alter Trudeau's thinking on NATO, and that "there was little anyone in Canada could do for the Czechs." 11 Shorter survey histories of Canadian foreign policy in the Trudeau era draw similarly succinct conclusions. ${ }^{12}$ Such works argue that the invasion was seen by the West as a setback for détente, but not a reason to abandon it. Trudeau's reaction is regarded as evidence of a certain tolerance he had for the Soviet Union; an acceptance of its sphere of influence. He and others sought to accelerate, not slow down, the push for warmer East-West relations. ${ }^{13}$

Trudeau himself passes over the crisis in his own memoirs. ${ }^{14}$ So does Minister of External Affairs Mitchell Sharp. ${ }^{15}$ The memoirs of other people involved in Canada's crisis response, in particular UN Ambassador George Ignatieff, tend to highlight their starring roles in more detail. ${ }^{16}$ In 1995, Trudeau published a book with Ivan Head, his foreign policy advisor. It too gives the crisis short shrift. While noting the "brutality of the Brezhnev

${ }^{11}$ See Robert Bothwell and J.L. Granatstein, Pirouette: Pierre Trudeau and Canadian Foreign Policy. (Toronto: University of Toronto Press, 1990), 17-18; 190-191; 380; Robert Bothwell, Alliance and Illusion: Canada and the World, 1945-1984 (Vancouver: UBC Press, 2007), 64-72; 284; 313; John Kirton's more theoretical, 2007 work, Canadian Foreign Policy in a Changing World, does not weigh in on the event specifically. See John Kirton, Canadian Foreign Policy in a Changing World (Toronto: Thomson Nelson, 2007), 128-134; 400; 513.

${ }^{12}$ See, for example, Norman Hillmer and J.L. Granatstein, For Better or For Worse: Canada and the United States into the Twenty-First Century. (Toronto: Thomson, 2007), 235; Norman Hillmer and J.L. Granatstein, Empire to Umpire: Canada and the World into the Twenty-First Century. (Toronto: Thomson, 2008), 250.

${ }^{13}$ See Robert Bothwell and J.L. Granatstein, Pirouette: Pierre Trudeau and Canadian Foreign Policy. (Toronto: University of Toronto Press, 1990), 17-18; 190-191; 380; Robert Bothwell, Alliance and Illusion: Canada and the World, 1945-1984 (Vancouver: UBC Press, 2007), 64-72; 284; 313;

${ }^{14}$ Pierre Trudeau, Memoirs (Toronto: McClelland \& Stewart Inc., 1993).

${ }^{15}$ Mitchell Sharp, Which Reminds Me...A Memoir. (Toronto: University of Toronto Press, 1994).

${ }^{16}$ See George Ignatieff, The Memoirs of George Ignatieff: The Making of a Peacemonger. (Toronto: University of Toronto Press, 1985); George Ball, The Past Has Another Pattern (New York: W.W. Norton \& Company, 1982); Robert Ford, Our Man in Moscow: A Diplomat's reflections on the Soviet Union. (Toronto: University of Toronto Press, 1989). 
Doctrine" the invasion made evident, the book emphasizes the hopes Trudeau had in 1968 "to seek a more orderly state of world affairs, where tensions could be relieved and conflicts resolved through structured, non-violent means."17 The invasion is not referenced in John English's 2009 biography of Trudeau. ${ }^{18}$

There are almost no journal articles dealing with Canada's reaction to the Soviet invasion of Czechoslovakia, let alone that of the entire NATO West. As John McGinn points out, a rich bibliography of literature surrounds the Prague Spring, but not the West's response to it. His 1999 piece, “The Politics of Collective Inaction: NATO's Response to the Prague Spring," is one exception. In it, he argues that the West purposely avoided any provocative support of the Prague Spring in the lead-up to the invasion. Rather than a more overt, coherent Alliance response backing Dubcek's reformist government and confronting its detractors, NATO nations favoured a quieter, back-channel way to deal with Soviet moves against Czechoslovakia. Anything more, particularly in the lead-up to the invasion itself, might have further undermined Dubcek's reforms in the eyes of the Soviets and heightened Cold War tensions. In the end, concludes McGinn, NATO's hands-off approach "not only failed to prevent the Soviet invasion, but may even have encouraged it." On the other hand, this tactic helped expose the "bankruptcy of Communist 'solidarity.",19

As in other instances, the US could turn to Canada as a useful proxy during the Czech crisis. McGinn finds no reason to explore Canada's role in the Western response. He does arrive at a similar conclusion about the crisis as Cold War scholar John Lewis

${ }^{17}$ See Ivan Head and Pierre Trudeau, The Canadian Way: Shaping Canada's Foreign Policy, 1968-1984. (Toronto: McClelland \& Stewart Inc., 1995), 7, 220-221; 263.

${ }^{18}$ John English, Just Watch Me: The Life of Pierre Elliot Trudeau, Vol. Two, 1968-2000 (Toronto: Vintage Canada, 2009).

19 John McGinn, "The Politics of Collective Inaction: NATO's Response to the Prague Spring," Journal of Cold War Studies, vol. 1, no. 3 (Fall, 1999): 111-114; 119-122; 126; 129; 136; 138. 
Gaddis concerning America's preoccupation with Vietnam at the time. ${ }^{20}$ Gaddis writes that the Soviet invasion of Czechoslovakia "caught the administration off guard, able to do little in response" and counts it, among other world events, as a problem that Vietnam had distracted American officials from dealing with more contextually, more reflectively. ${ }^{21}$

Laura Madokoro's article focuses on the Canadian government's handling of the movement of Czechoslovakian migrants to Canada stemming from the invasion. It punctuates the "self-serving" nature of Canada's efforts. She argues that the Trudeau government sought a refugee strategy that would not only be consistent with working towards increased détente with the Soviet Union, but also serve Canada's immediate economic self-interest. ${ }^{22}$ The Madokoro narrative emphasizes the primarily economic motivations driving the government to act on the "humanitarian" front. Madokoro also notes, however, that the Canadian government "stepped back from using the humanitarian crisis for propaganda purposes." It not only desired a warming of relations between East and West, but also wanted to "avoid encouraging a mass exodus, which would upset the Soviets and liberal elements in Czechoslovakia."23

Though Madokoro does not identify him by name in her work, this latter position was championed, unsuccessfully, by Under-Secretary of State for External Affairs Marcel Cadieux. Brendan Kelly explores this early period of Trudeau's foreign policy with an examination of the archival record left behind by the most senior bureaucrat at the Department of External Affairs (DEA). In his 2017 International Journal article, "The

\footnotetext{
${ }^{20}$ McGinn, "The Politics,” 119-121; 126.

${ }^{21}$ John Lewis Gaddis, Strategies of Containment: A Critical Appraisal of Postwar American National Security Policy (New York: Oxford University Press, 1982), 270.

22 Madokoro, "Good," 168.

${ }^{23}$ Madokoro, “Good,” 162-163; 166.
} 
Politician and the Civil Servant," Kelly highlights a contrast between Trudeau and Cadieux, offering a fresh perspective on the already well-documented "difficult adjustment" for the Department in these early days of the Trudeau government. The invasion of Czechoslovakia was among the first tests of this adjustment between the new governing style of the "brilliant politician" and the "consummately professional civil servant." In the context of Kelly's much broader work, however, the invasion merits only a few passing references, again in its connections to later discussions over NATO reductions rather than what happened at the time of the Czech crisis itself. ${ }^{24}$

Neither Madokoro nor Kelly explore the vigour with which Cadieux questioned the Trudeau government's approach to international relations during the Czech crisis. It is this tension, among other differences, which this work sets out to explore in more detail. The Czech crisis accentuated two key disagreements between Trudeau and his top bureaucrat at the DEA: the future of Canada's contribution to NATO in Europe, and concerns that the Under-Secretary would have with the Trudeau cabinet's decisions on refugees. The crisis also sheds light on differences of opinion that Trudeau, Cadieux, and others had on Canada's role at the UN, as well as the relevance of the DEA itself. Lastly, while Trudeau and Sharp might have hoped to move beyond it, the Czech crisis demonstrates that the Cold War was very much on the minds of others in government agencies beyond the DEA. Filmmakers at the National Film Board of Canada (NFB) found ways to expose what they saw as the true ugliness of the Soviet occupation, while for agents of the RCMP, it was business as usual in the fight against communism at home and abroad.

${ }^{24}$ Kelly Brendan, "The politician and the civil servant: Pierre Trudeau, Marcel Cadieux, and the DEA, 19681970," International Journal 2017, vol.72 (I): 5-7; 12-13; 15. 
While not unusual in the formulation of foreign policy, the existence of such differences was an underlying characteristic of the Trudeau government's crisis response. Further probing reveals a delusory quality about each of these perspectives. In the end, an inexperienced government failed to heed some of the more competent advice it received concerning how best to meet Canada's interests during the crisis. National interest was an understandable objective, but in this case, it was pursued at Czechoslovakia's expense.

Chapter one begins with an examination of the government's first reaction to the crisis - an initial misstep. It continues by exploring the question of Canada's undertakings at the UN. Despite both Trudeau and Sharp's lack of enthusiasm, Cadieux, Ambassador George Ignatieff, and the Trudeau cabinet took the country's role there seriously. To them, Canada stood to benefit from being at the table in New York - even if Czechoslovakia did not. Cadieux's differences with Trudeau on the question of Canada's NATO forces in Europe, brought into focus during the Czech crisis, are explored next, along with further analysis of the wishful thinking that so pervaded the government's thoughts on Czechoslovak liberalization and détente as the crisis unfolded. A desire to accelerate the end of the Cold War, coupled with an utter failure to punish Soviet aggression, is contrasted later in the chapter with a view of how filmmakers at the NFB and agents at the RCMP responded to the crisis. The end of this chapter finds Trudeau one week into the occupation confirming his rather critical view of the DEA, notwithstanding the benefits his new government continued to receive from its work as the international crisis played out.

Chapter two analyzes how a political promise made by the Minister of External Affairs evolved into a special refugee programme set up by the Canadian government for Czechoslovakians wishing to leave their country. These were, for the most part, not 
refugees. A poorly-worded pledge made on humanitarian grounds quickly became an economic undertaking. This helped Canada, but as Cadieux repeatedly warned, was detrimental to Czechoslovakian society. It was the surest sign of inexperience at the helm as a new government faced its first international crisis. 


\section{Chapter One}

The Political Interest

\section{The Lead-Up}

Both Canada and Czechoslovakia tried political experiments of liberation in 1968. Pierre Trudeau was elected leader of his governing Liberal Party on 6 April. The Liberals won the subsequent election on 25 June. Trudeau held the first post-election meeting of his new cabinet on 8 July. He told his ministers he would to give them time off from 20 July to mid-August. Until then, they would meet to prepare for the upcoming session of Parliament, which had not sat since 23 April. $^{25}$ In his memoir, then-External Affairs Minister Mitchell Sharp describes how, "in the first few months after the 1968 elections, under Trudeau's leadership, the Cabinet Committee on Priorities and Planning was a seminar in political science...I don't think the debate could have been equaled for intellectual stimulation in any Canadian university." ${ }^{26}$ Trudeau basked in the glow of his election victory and the "Trudeaumania" that accompanied it. ${ }^{27}$

Change had taken hold of Czechoslovakia that spring. Dubcek began democratic reforms in January after ousting Stalinist-leaning Antonin Novotny from the Communist Party leadership. The Prague Spring saw the introduction to Czechoslovakia of a free press, contested elections, and a responsible parliament. The Toronto Star's Greg Allen wrote that "[i]n the little world of eastern Europe, where power is shared by a half dozen all-

${ }^{25}$ As noted earlier, English sees Trudeau's election in 1968 as reflecting the spirit of the times - the storied spring of 1968 which, of course, included "the liberation of the Prague Spring." See English, Just, 1; 29; 3132; 41; George Bain, "Stanfenbaker or Diefenfield," The Globe and Mail, 20 August 1968, A6; "The long ago," The Globe and Mail, 14 August 1968, A6.

${ }^{26}$ Mitchell Sharp, Which Reminds Me...A Memoir. (Toronto: University of Toronto Press, 1994), 165.

${ }^{27}$ An enthusiasm for Trudeau, called Trudeaumania by the media, emerged during the 1968 election campaign. In his memoirs, Trudeau observes that "the phenomenon was part of the spirit of the times," an aspect of the festive mood of the country generated by the Centennial celebrations and Expo 67. See Trudeau, Memoirs, 99-100; Richard Gwyn, The Northern Magus: Pierre Trudeau and Canadians. (Toronto: McClelland \& Stewart Inc., 1980), 71. English, Just, 1-3; 32. 
powerful leaders," Dubcek "became both a hero and a heretic." ${ }^{28}$ From Prague, Canadian Chargé d'affaires Cole observed of Dubcek that "the people's idolization of this man is...very moving[,] and it would appear that he is not immune to its spell." ${ }^{29}$

Despite Dubcek's declaration of loyalty to the Warsaw Pact, the Soviets started tightening their grip on his country in May, initiating troop manoeuvres near the Czech border. By July, these had turned into the largest moves by the Soviet army since World War II, lingering long enough across the border in Czechoslovakia to raise suspicions. Political pressure from the Kremlin and the other Warsaw Pact countries mounted as Dubcek refused to be bullied into clarifying or lessening the intensity of his new approach. He appeared to give in somewhat after two high level meetings with the Soviets that look place in Czechoslovakia. The Cierna meetings on 29 and 30 July were attended by the entire Soviet politburo. In Bratislava, the Czechoslovakian leadership was met on 3 August by their counterparts not only from the Soviet Union, but also East Germany, Poland, Hungary, and Bulgaria. ${ }^{30}$

The timing of the invasion caught the West off-guard. It was not, however, a complete surprise to Canada and its allies. In the weeks leading up to the crisis, whether or not the Soviets would invade Czechoslovakia was subject to much internal debate. In August, Canada's DEA and its Western counterparts closely monitored the relationship between Czechoslovakia and the Kremlin. ${ }^{31}$ Developments earlier in the month led Canada's diplomats and officials at home to believe that the Soviet Union was not going to intervene but that a very real threat remained. At the time, there was no Canadian

\footnotetext{
${ }^{28}$ Greg Allen, "Dubcek: His choices ran out at last," Toronto Star, 22 August 1968, A7.

${ }^{29}$ LAC, RG 25, Vol. 8907, File 20, Part 4. Cole to External Affairs, 18 August 1968.

30 “The Red army was Russia's final argument," Toronto Star, 21 August 1968, A9.

${ }^{31}$ See LAC, RG 25, Vol. 8907, File 20, Parts 3-10 and Vol. 8908, File 20, Parts 11-18.
} 
Ambassador in Prague. The ambassadorship to Czechoslovakia (and Hungary) had just been vacated by M.N. Bow, ${ }^{32}$ who thought that the Czechs and Russians had arrived at an understanding over Moscow's concerns with the Dubcek reforms. ${ }^{33}$ Ambassador Robert Ford in Moscow was similarly optimistic. ${ }^{34}$

After the Cierna meetings, Cole reported from Prague a deepening uncertainty hanging over the country. "Understandably," he wrote, "there is considerable skepticism today whether this country is out of the woods yet." ${ }^{35}$ Ambassador to Poland Pamela Ann McDougall described the situation as a "rather anxious period of waiting" to know "what use, if any, the Soviet troops which now ring Czechoslovakia will be put."36 The Czechs, the Embassy in Bonn observed, were "on probation." ${ }^{37}$ Reports and analysis on both the prospects and outcome of the six-power communist conference in Bratislava several days later contained more hopeful notes. ${ }^{38}$ Nonetheless, the DEA told Sharp on 9 August that, with Warsaw Pact forces deployed on the Czechoslovak borders remaining in strength, "the threat of military intervention has not disappeared." 39 Ottawa, London, and

32 Ottawa Bureau, "Invasion disappointing to Sharp, "no immediate threat to peace,"” The Globe and Mail, 21 August 1968, A1.

${ }^{33}$ Ottawa Bureau, "It'll set our relations back years says Sharp of Soviet invasion," Toronto Star, 21 August 1968, A1.

${ }^{34}$ LAC, RG 25, Vol. 8907, File 20, Part 3. The Office of the High Commissioner for Canada, Canberra, to the Under-Secretary of State for External Affairs, 2 August 1968; Ford to External Affairs, 1 August 1968.

${ }^{35}$ LAC, RG 25, Vol. 8907, File 20, Part 3. Canadian Embassy, Prague to the Under-Secretary of State for External Affairs, 1 August 1968.

${ }^{36}$ LAC, RG 25, Vol. 8907, File 20, Part 3. Canadian Embassy, Warsaw to the Under-Secretary of State for External Affairs, 1 August 1968.

${ }^{37}$ LAC, RG 25, Vol. 8907, File 20, Part 3. Canadian Embassy, Bonn, to External Affairs, 7 August 1968.

${ }^{38}$ LAC, RG 25, Vol. 8907, File 20, Part 3. Ford to External Affairs, 2 August 1968; Ford to External Affairs, 4 August 1968; Cole to External Affairs, 6 August 1968.

${ }^{39}$ The memorandum containing this assessment is marked as "Seen by Minister." See LAC, RG 25, Volume 8907, File 20, Part 3. "Czechoslovak Situation: Political Assessment," Department of Foreign Affairs, 9 August 1968 (see also the original version of this memo prepared by G.L. Hearns, dated 6 August). 
Washington all concluded that the original threat of Soviet military intervention had been real, and that it still existed after Bratislava. ${ }^{40}$

Dubcek returned to Prague from the Bratislava conference insisting to a skeptical public that their newly instituted liberties remained in place. ${ }^{41}$ Cole reported on 8 August that Czechoslovak leaders were "continuing efforts to close the credibility gap about achievements at the Cierna and Bratislava summits." It appeared to him that "for the time being at least the Dubcek regime is solidly entrenched." It had survived both the Soviet military threat and the "summit ordeal" while retaining "overwhelming public support." Cole anticipated that this popularity would be further bolstered the following day by the visit of Yugoslavia's Josip Tito. ${ }^{42}$

The evolving relationship between the Soviet Union and Czechoslovakia was not a matter that had emerged onto the new Canadian Government's cabinet agenda prior to the invasion. ${ }^{43}$ On 15 August, the prime minister began what was planned to be a 10-day private holiday to Spain. Transport Minister Paul Hellyer would be acting prime minister. Assistant Secretary to the Cabinet Michael Pitfield, accompanying Trudeau, would keep

${ }^{40}$ For further pre-invasion analysis by the DEA, see LAC, RG 25, Vol. 8907, File 20, Part 3. "Czechoslovak Situation: Political Assessment," prepared by G.L. Hearns, European Division, DEA, 6 August 1968; "Czechoslovak Situation: Political Assessment," DEA, 9 August 1968; Ford to External Affairs, 8 August 1968; "Czechoslovak Situation: Political Assessment," DEA, 9 August 1968 (see also the original version of this memo prepared by G.L. Hearns, dated 6 August; "Czechoslovak Situation: Political Assessment," prepared by R.W. Murray, European Division, DEA, 14 August 1968; LAC, RG 25, Vol. 8907, File 20, Part 4. Ford to External Affairs, 16 August 1968; Canadian Embassy, Washington, D.C. to External Affairs, 1968; Canadian High Commission, London to External Affairs, 16 August 1968; LAC, RG 25, Vol. 8907, File 20, Part 3. Dupuy at North Atlantic Council (NATO) in Brussels to External Affairs, 5 August 1968; Dupuy at North Atlantic Council (NATO) in Brussels to External Affairs, 8 August 1968 and 13 August 1968.

41 "The Red army was Russia's final argument," Toronto Star, 21 August 1968, A9.

${ }^{42}$ LAC, RG 25, Vol. 8907, File 20, Part 3. Cole to External Affairs, 8 August 1968.

${ }^{43}$ LAC, RG 25, Vol. 8907, File 20, Part 3. "Czechoslovak Situation: Political Assessment," DEA, 9 August 1968; LAC, RG 2, Series A-5-a, Vol. 6338, Cabinet minutes, April - August, 1968. 
him abreast of any new developments in Canada and, presumably, abroad. ${ }^{44}$ Trudeau came under attack from former Prime Minister John Diefenbaker for neglecting his duties in rejecting the Conservatives' request for an earlier re-convening of Parliament. ${ }^{45}$ The Soviet invasion of Czechoslovakia would soon give the Opposition one more reason to call for Parliament to meet sooner rather than later. ${ }^{46}$

In Czechoslovakia, visits of support for Dubcek by Yugoslavian President Tito, as well as Nicola Ceausescu, the independent-minded communist leader of Romania, did follow in the days to come. ${ }^{47}$ R.W. Murray of the DEA's European Division observed that the visits offered "welcome encouragement to Czech spirits." ${ }^{\text {" }}$ As department analysts would later point out, however, they also provoked further ire from Moscow. The warm welcome that Tito and Ceausescu received during their post-Bratislava visits stood in stark contrast to the one East German leader Walter Ulbricht received during his. "Czechoslovakia seemed openly to be associating itself with countries whose foreign policy was often opposed to Moscow's" and "which denied the leading role of the USSR in the international ideological movement." ${ }^{49}$ Cole noted that the attempt to keep the Tito visit in low key was not entirely successful. ${ }^{50}$

${ }^{44}$ Ottawa Bureau, "Trudeau sneaks out of Ottawa, flies to 'secret' holiday in Spain." The Globe and Mail, 17 August 1968, A1.

${ }^{45}$ George Bain, "Stanfenbaker or Diefenfield," The Globe and Mail, 20 August 1968, A6; "The long ago," The Globe and Mail, 14 August 1968, A6.

${ }^{46}$ Quebec Bureau. "Stanfield cites Red invasion in seeking Parliament's recall," The Globe and Mail, 23 August 1968, A8.

${ }^{47}$ Mark Gayn, "Pro-Soviet regime expected within 48 hours," Toronto Star, 21 August 1968, A8.

${ }^{48}$ LAC, RG 25, Vol. 8907, File 20, Part 3. "Czechoslovak Situation: Political Assessment," prepared by R.W. Murray, European Division, DEA, 14 August 1968.

${ }^{49}$ LAC, RG 25, Vol. 8907, File 20, Part 8. "Memorandum for the Minister - Soviet Occupation of Czechoslovakia: Motives and Timing." 27 August 1968; Mark Gayn, "Pro-Soviet regime expected within 48 hours," Toronto Star, 21 August 1968, A8.

${ }^{50}$ LAC, RG 25, Vol. 8907, File 20, Part 4. Cole to External Affairs, 18 August 1968. 
From Moscow, Ford observed what had been, over the last few days, a "marked change of tone" in the Soviet media towards Czechoslovakia. It contained, among other things, criticism of the Czechoslovakian press for its “'fierce and slanderous' attacks on Communist neighbours contrary to the spirit of the Bratislava Agreement." This "particular frustration and annoyance at a continued lack of restraint being exercised by the Czech press" was perhaps "exacerbated by the triumphant post-Bratislava tone of the Western press and by the success of the recent Tito and Ceausescu visits." ${ }^{\text {51 }}$ Canada's High Commission in London reported that the UK Foreign Office thought that the "warm reception and [international] publicity accorded these visits [was] undoubtedly galing [sic] to Moscow." Given the "rising note of exasperation with Czechoslovakia shown by the Soviet press," the Foreign Office thought that "the question mark about the durability of the Bratislava and Cierna understandings was growing larger.” In particular, assurances that Dubcek had apparently given at the summits that "guidance and self-restraint" would be effective enough to curb "irresponsible Czech journalism" were not, in the eyes of the Kremlin, panning out:

Essentially self-restraint has worked and the main organs of Czech communications have observed discretion on sensitive matters affecting the Soviet Union. However and almost inevitably[,] voluntary discipline has been broken by some who have found intoxicating the experience of six months of virtually unfettered expression irresistible[,] but the Russians are not prepared to condone any exceptions. ${ }^{52}$

${ }^{51}$ LAC, RG 25, Vol. 8907, File 20, Part 4. Ford to External Affairs, 19 August 1968.

${ }^{52}$ LAC, RG 25, Vol. 8907, File 20, Part 4. Canadian High Commission, London to External Affairs, 16 August 1968. 
In addition to ratcheting up its propaganda efforts to undermine Dubcek's liberal government in Prague, the Soviet Union had already announced plans for additional military manoeuvres along the Czechoslovakian border. ${ }^{53}$

Ottawa was briefed on what apparently were attempts by the Soviets to manufacture the appearance of "counter-revolutionary" activity in Czechoslovakia. The "significant increase in diatribe" that Ford had observed in the Soviet media included accusations of "anti-socialist forces" being incited by the West to intrigue against Communist Party rule. ${ }^{54}$ Cole sent Cadieux a memorandum on 16 August concerning an arms cache discovered in Western Bohemia. The Czechoslovak Ministry of the Interior suspected pro-Soviet perpetrators, probably East Germans, of planting the cache of World War II-era, US-made weapons "as part of a plot to strengthen the hand of conservative forces in Czechoslovakia, so as to justify Soviet military intervention to put down 'counter revolutionary forces."” Cole wrote that Czech authorities remained "determined to discredit completely what they consider to have been a bold and clumsy attempt to interfere with the normal course of events in their country." 55

Pravda, the Soviet Communist Party's official newspaper, was now issuing promises of neighbourly support to Czechoslovakia's workers to rebuff the "subversive activities by anti-socialist forces" plotting against a chaotic Czech government. ${ }^{56}$ The paper revived a story about a letter that it had originally published on 30 July from pro-Soviet workers in a Czech factory urging the Soviets to station troops in Czechoslovakia.

\footnotetext{
${ }^{53}$ AP-Reuters, "Czechoslovak border area: New Red manoeuvres planned," The Globe and Mail, 12 August 1968, A1.

${ }^{54}$ LAC, RG 25, Vol. 8907, File 20, Part 4. Ford to External Affairs, 19 August 1968.

${ }^{55}$ LAC, RG 25, Vol. 8907, File 20, Part 4. Canadian Embassy, Prague to Under-Secretary of State for External Affairs, 16 August 1968.

${ }^{56}$ New York Times Service, “'Anti-socialist forces:' Prague liberals losing control, Pravda claims,” The Globe and Mail, 19 August 1968, A1.
} 
According to Pravda, the signatories of the letter were being hounded by anti-communist plotters and the government was allowing this "organized persecution" to go unchecked. ${ }^{57}$ In his 19 August communiqué to Ottawa, Ford suggested that the re-emergence of this story in Pravda was further reason to "remain anxious," but that it was "difficult to believe that they could once again crank up their propaganda machinery to generate a level of tension with Czechoslovakia comparable to that existing between the two countries prior to Cierna." 58 Ford was wrong. They were doing more than that. The Soviet Union was laying the groundwork for an invasion.

\section{The Invasion}

As the invasion took place on the morning of 21 August, Cole wrote that the Central Committee of the Czechoslovakian Communist Party had been meeting late into the night preparing for the $14^{\text {th }}$ Party Congress when, at 11:00 p.m., it received a report of the border crossings from "allied countries." A statement issued several hours later from a combined emergency meeting of the Central Committee and the National Assembly said that no resistance should be offered since "we have no means of defence." By 6:00 a.m., with Prague Castle completely surrounded and its guards disarmed, Czechoslovak leaders had been taken into custody. ${ }^{59}$ On the front page of its official newspaper Rude Pravo that morning, the Central Committee of the Communist Party of Czechoslovakia declared that the invasion of their country by Warsaw Pact troops had taken place without the consent of the Czechoslovakian government. The invasion was not only "incompatible with the

\footnotetext{
${ }^{57}$ Anderson, Raymond. "Czechs face new attack from Soviet." The Globe and Mail, 20 August 1968, A8. ${ }^{58}$ LAC, RG 25, Vol. 8907, File 20, Part 4. Ford to External Affairs, 19 August 1968.

${ }^{59}$ LAC, RG 25, Vol. 8907, File 20, Part 4. Messages (750, 755, and 759), Cole to External Affairs, 21 August 1968; Vincent Buist, "Gunfire, phone wires ripped out and a cold meal: How Russian soldiers hustled a handcuffed Dubcek out of Prague," The Globe and Mail, 29 August 1968, A1.
} 
principles of relations among the socialist states but also a violation of the basic norms of the international law." The statement concluded with the Presidium of the National Assembly appealing to the invading states to withdraw. ${ }^{60}$

"With dawn," Cole reported, "the enormity of the situation [was] being fully appreciated by Czechoslovaks" and public shock was "extremely pronounced." 61 There were indications, wrote Cole, that "moral resistance" to the invading forces was growing. Young Czechs with large Czechoslovak flags on their motorbikes drove by the Embassy against a backdrop of scattered machinegun fire and the occasional explosion. ${ }^{62}$ Shots, he was told, had been fired by Soviet troops over the heads of several hundred demonstrators as they marched near Prague Castle. Canadians attending a geological congress were calling the Embassy and being told to remain in their hotels. ${ }^{63}$

Radio and television stations in Prague and other cities were still on the air and "broadcasting defiance." There were reports of Czechs being shot defending the Prague station. ${ }^{64}$ According to the same unverified information compiled and sent to Ottawa that morning by Cole, a popular radio broadcaster named Janicek announced over the air that the tanks were on their way to the radio station. "We will remain as long as possible," he said. "You know our voice. It may change." After a broadcast of the Czechoslovak national anthem, apparent shots fired, and a "final plea for freedom and democracy," the station

${ }^{60}$ LAC, RG 25, Vol. 8907, File 20, Part 4. Message (751), Cole to External Affairs, 21 August 1968; "Statement by the Presidium of the Central Committee of the Communist Party of Czechoslovakia," stamped "Embassy of the Czechoslovakian Socialist Republic, Ottawa"; LAC, RG 2, Series A-5-a, Vol. 6338, Cabinet minutes, 21 August 1968. 2-4.

${ }^{61}$ LAC, RG 25, Vol. 8907, File 20, Part 4. Message (752), Cole to External Affairs, 21 August 1968.

${ }^{62}$ LAC, RG 25, Vol. 8907, File 20, Part 4. Message (754), Cole to External Affairs, 21 August 1968.

${ }^{63}$ LAC, RG 25, Vol. 8907, File 20, Part 4. Messages (752, 754, and 755), Cole to External Affairs, 21 August 1968.

${ }^{64}$ LAC, RG 25, Vol. 8907, File 20, Part 4. Message (751, 754, and 755), Cole to External Affairs, 21 August 1968. 
went off the air at about 8:15 a.m. ${ }^{65}$ As the second of two underground radio stations that went on the air that day expected to be shut down in the early afternoon, Cole reported its final appeal: "These invaders cannot operate in this country without new leaders. Czechoslovak citizens are requested not to cooperate with them. We have our elected leaders. ${ }^{966}$ Reports containing assessments of the invasion began to pour into Ottawa from Canada's other missions around the world, as well as from the embassies and high commissions of other countries situated in the Canadian capital. ${ }^{67}$

\section{Sharp's Initial Reaction}

A contrast in approach became immediately evident as word of the invasion arrived in Ottawa. Prime Minister Trudeau was still holidaying in Spain. External Affairs Minister Mitchell Sharp had been well briefed on the possibility of an invasion, but now that it had happened, he initially said he saw no concern for Canada, and expressed little sympathy for Czechoslovakia. The invasion was, in his view, Czechoslovakia's own affair. In comparison to that of Canada's allies, the reaction was mild, uninformed, and lacking in urgency. Observers quickly cited a need for a more robust response from Canada, and so did Sharp's cabinet colleagues.

There was no shortage of reports from the occupied Czechoslovakian capital and elsewhere already in the hands of the DEA's European Division. A statement would be ready for Sharp's use on the morning of 21 August. News of the invasion, however, came over the North American airwaves the night before. This was when, at 10:30 p.m. Ottawa

${ }^{65}$ LAC, RG 25, Vol. 8907, File 20, Part 4. Messages (754, 755, 759, 768, and 775), Cole to External Affairs, 21 August 1968.

${ }^{66}$ LAC, RG 25, Vol. 8907, File 20, Part 4. Message (759), Cole to External Affairs, 21 August 1968.

${ }^{67}$ The deluge of telexes and other communications continued for weeks to come. See LAC, RG 25, Vol. 8907, File 20, Parts 3-10 and Vol. 8908, File 20, Parts 11-18. 
time, Sharp was asked by the press for reaction. ${ }^{68}$ His comments appeared on the front pages of the country's newspapers the next morning. These stories had headlines like that of the Globe and Mail: "SOVIETS OCCUPY CZECHOLOVAKIA, PRAGUE YOUTHS FIRE ON TANKS."

That night, wrote the Globe, Sharp said the invasion was "very disappointing."70 "Expressing shock at the invasion," reported the Toronto Star, the Minister observed that it was a "sad world we live in." "All of us who value freedom and who had been hoping for an improvement in relations between East and West are very disappointed." Not as in command of his department's political assessments as he could have been, Sharp suggested that "[a]ll intelligence reports indicated Russia had abandoned any idea of military intervention."71 The Globe quoted him saying that there was "bound to be a great setback to the growing confidence in Europe and progress toward an East-West détente," but there was little that Canada could do "or little that we need to fear about the outbreak of hostilities." Based on Czechoslovakia's lack of resistance to the Soviet advance, Canada's External Affairs Minister quickly concluded that it did not pose an immediate threat to peace. "[A]s far as we can see," he said, "it relates entirely to Czechoslovakia," adding that

${ }^{68}$ LAC, RG 25, Vol. 8907, File 20, Part 4. Canadian Press account of interview with Secretary of State for External Affairs at 10:30 p.m. EDT, 20 August 1968 as found in message from External Affairs to Canadian permanent delegation, NATO Council in Brussels, 21 August 1968.

69 "It'll set our relations back years says Sharp of Soviet invasion," Toronto Star, 21 August 1968, A1; LAC, RG 25, Vol. 8907, File 20, Part 4. Canadian Press account of interview with Secretary of State for External Affairs at 10:30 p.m. EDT, 20 August 1968 as found in External Affairs, to Canadian permanent delegation, NATO Council in Brussels, 21 August 1968; Front page headlines, The Globe and Mail, 21 August 1968, A1.

${ }^{70}$ Ottawa Bureau, "Invasion disappointing to Sharp, "no immediate threat to peace,"” The Globe and Mail, 21 August 1968, A1.

71 "It'll set our relations back years says Sharp of Soviet invasion," Toronto Star, 21 August 1968, A1. 
he expected the issue would be taken up at the UN. ${ }^{72}$ The Toronto Star reported Sharp describing the invasion as a "row within the Communist bloc.",73

The Americans and the British took a different attitude. Several hours before Sharp was interviewed, US President Lyndon Johnson was informed of the troop movements by Soviet Ambassador Anatoly Dobrynin in a face-to-face meeting at the White House. Canada's diplomats in Washington reported that Johnson met with Dobrynin around 8:00 p.m., although the ambassador had requested a meeting two hours earlier, just as the Soviets would have been crossing the border into Czechoslovakia. ${ }^{74}$ Afterwards, the president summoned the National Security Council for a meeting that lasted almost an hour, the first such emergency session of the group in over a year. ${ }^{75}$ The Council convened again that night after a second, midnight, meeting with Dobrynin, this time with Secretary of State Dean Rusk. ${ }^{76}$ British Prime Minister Harold Wilson, whose government, like the Americans, had received a Soviet diplomatic note on the situation, cut short his summer vacation and returned to London to convene his cabinet. ${ }^{77}$

In Canada's case, however, there was no plan to get in touch with Trudeau on holiday. Nor did Sharp have immediate plans to discuss the situation with Acting Prime Minister Paul Hellyer. Sharp told the press that he would later decide whether or not to

72 Ottawa Bureau, "Invasion disappointing to Sharp, "no immediate threat to peace,"” The Globe and Mail, 21 August 1968, A1;

73 "It'll set our relations back years says Sharp of Soviet invasion," Toronto Star, 21 August 1968, A1.

${ }^{74}$ LAC, RG 25, Vol. 8907, File 20, Part 4. Messages (3069 and 3075), Canadian Embassy, Washington, D.C. to External Affairs, 21 August 1968.

75 AP, "Soviet diplomat tells Johnson," The Globe and Mail, 21 August 1968, A1.

${ }^{76}$ Robert Reguly, "Western countries shocked but they plan no intervention," Toronto Star, 21 August 1968, A1, A4.

77 J.E.G. Hardy, Canada's Deputy High Commissioner in London, informed Ottawa that according to the Foreign Office, Soviet Ambassador called Lord Chalfont at 1:30 a.m. with a similar message to pass on to Prime Minister Wilson. See LAC, RG 25, Vol. 8907, File 20, Part 4. Message (4040), Hardy at Canadian High Commission, London to External Affairs, 21 August 1968; Robert Reguly, "Western countries shocked but they plan no intervention," Toronto Star, 21 August 1968, A1, A4. 
take the issue to the cabinet. ${ }^{78}$ Department officials, meanwhile, were "gathering all available reports on the situation and would review it with him early in the morning."79 The minister called that briefing for 8:30 a.m. ${ }^{80}$

In a meeting about the invasion with a delegation of mostly CzechoslovakCanadian businessmen two days later, Sharp explained his "mild initial reaction." "I was concerned," he said, "that there might be some panic among Canadians that the third world war was about to start." ${ }^{\prime \prime 1}$ It was a political miscalculation. The Canadian government's initial response to the invasion that first night would come quickly under attack from Czechoslovakian Canadians, the Opposition, and the nation's print media. A delegation from the Toronto-based Masaryk Memorial Institute and three other CzechoslovakCanadian organizations was already on its way to the capital. The Institute's president, Ervin Syptak, said his group was "very disappointed" with Sharp. Dubcek, he said, "was a very honest man who needed the support of the world. And now he is finished." The delegation of six flew to Ottawa to seek an appointment with Sharp. They hoped to exert pressure on the Canadian government to take a firmer stand. Syptak, himself a refugee from the Communist seizure of power in Czechoslovakia in 1948, told the Star that "[w]e are planning something big, not here, but in Ottawa." 82

${ }^{78}$ Reuters, "Elusive PM leaves resort for Madrid," The Globe and Mail, 21 August 1968, A4; "World Reaction," The Globe and Mail, 22 August 1968, A1; Ottawa Bureau, "Invasion disappointing to Sharp, "no immediate threat to peace,"” The Globe and Mail, 21 August 1968, A1; Ignatieff, Memoirs, 225.

${ }^{79}$ LAC, RG 25, Vol. 8907, File 20, Part 4. Canadian Press account of interview with Secretary of State for External Affairs at 10:30 p.m., EDT, 20 August 1968 as found in External Affairs, to Canadian permanent delegation, NATO Council in Brussels, 21 August 1968.

${ }^{80}$ Ottawa Bureau, "Invasion disappointing to Sharp, "no immediate threat to peace,"” The Globe and Mail, 21 August 1968, A1.

${ }^{81}$ Ottawa Bureau, "Sharp promises Czech refugees ready welcome," The Globe and Mail, 23 August 1968. A9; Ottawa Bureau, "Canada will welcome Czech refugees: Sharp," Toronto Star, 22 August 1968, C1.

${ }^{82}$ Ottawa Bureau, "Invasion disappointing to Sharp, "no immediate threat to peace," The Globe and Mail, 21 August 1968, A1; "10,000 Metro Czechs await news of relatives," Toronto Star, 21 August 1968, A69; Ottawa Bureau, "Crisis brings Trudeau home," Toronto Star, 21 August 1968, A1. 
Opposition Leader Robert Stanfield pounced on Sharp's Tuesday evening remarks. On Wednesday, he said that "Canada should take the lead in bringing world opinion to condemn the invasion" and that Sharp "should have reflected the strong feelings of the Canadian people." He characterized Sharp's remarks as a "non-committal reaction." Progressive Conservative Party President Dalton Camp wrote that Sharp's initial response was "feeble." John Diefenbaker's position emphasized how "short-lived and superficial" the Soviet pretensions to "a more enlightened attitude" was now revealed to have been. He directed his attack on the Trudeau government's broader, nascent foreign policy plan. Diefenbaker related the invasion to recent "propaganda" from the government about the possibility of a "reduction, if not a removal of Canadian troops from NATO." The invasion, he said, confirmed that any such diminishment of Canada's NATO contribution "would be another case of the ostrich burying its head in the sand." 83

The Star argued on Wednesday that it was "scarcely reassuring" to hear Sharp "announce soothingly" how "regrettable" the invasion was but that it was not "a threat to peace." In a column published on Thursday, the Globe's Scott Young wrote that Sharp had "become a diplomat in a hurry." The "connotation" of Sharp's remarks was that Canada was "rather out of sorts" about the invasion, but that it was "nothing that a good laxative wouldn't fix." Young's sarcasm turned to embarrassment. The government, "represent[ing] us in all the world news round-ups," had failed to convey the "heartsick[ness]" Canadians truly felt. Sharp makes no mention of the incident in his memoirs, but George Ignatieff, Canada's then-UN Ambassador, does in his. Sharp's

\footnotetext{
${ }^{83}$ Anthony Westell, "Sharp hands Red diplomats Cabinet statement protesting against invasion," The Globe and Mail, 22 August 1968, A9; Dalton Camp, "Hobbled by ourselves," The Globe and Mail, 31 August 1968, A9.
} 
reaction, he writes, was "almost incredibly mild." 84 The minister's approach to this international crisis would not do.

A More "Vigorous" Response

The crisis was a matter considered at the highest levels of the Canadian government for several weeks, and one which occupied a significant amount of attention at External Affairs. The cabinet concluded that "there was very little in a practical way that Canada could do. ${ }^{95}$ However, these and other decision-makers involved in Canada's response saw ways that Canada stood to benefit from the situation. Participating in, if not coordinating, the Western response to the invasion, no matter how futile that might be, brought with it an appealing international profile. But being in this arena demanded the appearance of urgency and competence. External Affairs stood ready to assist. With the benefit of further briefings from DEA officials, the tone of the government's response changed overnight. Sharp had decided to take the matter to cabinet, already scheduled to meet that Wednesday morning. He spoke on the phone with the vacationing Trudeau, advised him to come home, and came to the cabinet meeting with a proposed government statement in hand. The invasion was the meeting's top agenda item. ${ }^{86}$

The cabinet determined that the prime minister, and Canada, needed to assume the appearance of a stronger voice in the crisis. There "was a continuing ideological confrontation with the Soviet Union and there would be strong pressure from the Eastern European communities in Canada for the Canadian government to play a vigorous role in

84 "The Rape of a Nation: Stalin's spirit breathes again," Toronto Star, 21 August 1968, A6; Scott Young, "Times when some words are not enough to describe one's feelings," The Globe and Mail, 22 August 1968, A7; Ignatieff, Memoirs, 234.

${ }^{85}$ LAC, RG 2, Series A-5-a, Vol. 6338. Cabinet minutes, 21 August 1968. 1-6.

${ }^{86}$ LAC, RG 2, Series A-5-a, Vol.6338, 21 August 1968. Cabinet minutes, 1-6; LAC, RG 25, Vol. 8907, File 20, Part 4. "Statement by the Secretary of State for External Affairs." 
these diplomatic developments." The cabinet agreed that Trudeau should come home immediately. Trudeau, Sharp said, had asked him whether or not it might be advisable for him to return via London so he could meet with British Prime Minister Wilson. The ministers agreed that he should not call upon the British leader before he had conferred with his own colleagues at home. ${ }^{87}$

The cabinet discussed what it could be doing "diplomatically by way of public protest." ${ }^{88}$ Canada was at that time serving a two-year term on the UN Security Council. ${ }^{89}$ The DEA and the Canadian delegation in New York had already been active that day. Consultations among WEO (Western European and Others) Security Council members had begun. ${ }^{90}$ From Brussels, Canada's delegation to the North Atlantic Council reported that the Council's Acting Secretary-General, Canadian James Roberts, had called a special meeting to discuss the invasion. The North Atlantic Council would remain focused on any unusual activity on NATO frontiers. On that first day, wrote Counsellor D.C. Arnould, there had been none. ${ }^{91}$ NATO was, for the time being, avoiding any actions "which however falsely interpreted could offer a pretext for Soviet action.",92

87 LAC, RG 2, Series A-5-a, Vol. 6338. Cabinet minutes, 21 August 1968. 1-6.

88 LAC, RG 2, Series A-5-a, Vol. 6338. Cabinet minutes, 21 August 1968. 1-6.

89 Ignatieff, Memoirs, 231.

90 See LAC, RG 25, Vol. 8907, File 20, Part 4. Messages (2292-2293), Ignatieff (PRMNY) to External Affairs, 21 August 1968.

${ }^{91}$ LAC, RG 25, “Czech-1-3-USSR, Czech-political affairs,” Volume 8907, File 20, Part 4. Message (2002) from Arnould at NATO Council in Brussels to External Affairs, Ottawa, 21 August 1968; North Atlantic Council (page 33), Canadian Representatives Abroad [Directory], Department of External Affairs, December, 1968. Global Affairs Canada Digital Library, Jules Léger Library, Global Affairs Canada. $<$ http://www.gac.canadiana.ca $>$

${ }^{92}$ Much of the discussion in Brussels would revolve around whether or not the situation warranted NATO implementing any so-called measures of "military vigilance," and how that decision would be authorized. For example, while the Council made it clear that SACEUR's [Supreme Allied Commander, Europe] discretion to authorize measures that would put NATO in a state of military vigilance was not being altered, what reason would SACEUR have to do so in this situation before receiving any change in political guidance - guidance that had yet to be received from governments at home? The Council agreed, therefore, to "seek guidance on the desirability" of such measures "so as to in turn be able to guide SACEUR." The Canadian delegation informed Ottawa that General Parker, the Acting SACEUR, had expressed concern to Acting NATO Secretary General Roberts that any restriction of the SACEUR's authority regarding 
Cadieux had established a "Special Task Force" within the DEA to coordinate activities related to the crisis. ${ }^{93}$ Shortly before the cabinet convened, he had also met the British High Commission's Chargé d'affaires, Thomas Rogers, who requested the meeting to discuss the need for urgent UN Security Council action condemning the Soviet Union. ${ }^{94}$ Sharp told the cabinet that the British were eager for the Council as a whole to meet, and would seek a resolution condemning the occupation and calling for the withdrawal of foreign troops from Czechoslovakia. He suggested to cabinet that Canada could call the

military vigilance could prejudice his capability "to react promptly if required to do so." According to the Toronto Star, Canada's NATO officers in West Germany - in charge of the 6,000 soldiers and 6,000 airmen the country had stationed there - had by the first day been alerted to the invasion, but the Defence Department said that this did not "constitute putting the forces in a state of alert" (at least beyond that which they already, apparently, were in). Ultimately, the DEA told the delegation in Brussels that it was entirely appropriate to offer political guidance to SACEUR in what was a highly political situation, and that this did not constitute any alteration of approved alert procedures. In fact, "military vigilance measures adopted should be related to an assessment of the political situation." SACEUR should adopt those vigilance measures "which he considers militarily desirable while studiously avoiding any action which the Russians might interpret as preparations for a NATO military reaction to the Czech developments." What was important, Ottawa indicated, was not whether or not the Soviets were aware of these measures, but rather how they interpreted them. By the end of the day, Arnould reported that the question of guidance to be provided to SACEUR under these circumstances was resolved (to Parker's apparent satisfaction) along the lines of the Canadian position, with the exception that only covert measures of vigilance should be taken at the present time. The Council concluded that the situation in Czechoslovakia, though not increasing the threat to NATO, did raise the level of uncertainty, and thus increased the need for vigilance. See LAC, RG 25, Vol. 8907, File 20, Part 4. Messages (2003-2005; 2008-2009; 2011-2013), Canadian delegation, NATO Council in Brussels to DEA, Ottawa, 21 August 1968; LAC, RG 25, Vol. 8907, File 20, Part 4. Messages regarding the "Czech Situation" (Numbers G.210-G.211) from DEA, Ottawa to Canadian delegation, NATO Council in Brussels, 21 August 1968; LAC, RG 25, Vol. 8907, File 20, Part 5. Messages $(2026 ; 2030)$, Canadian delegation at NATO Council in Brussels to DEA, Ottawa, 22 August 1968; LAC, RG 25, Vol. 8907, File 20, Part 6. Message (2043), Canadian delegation at NATO Council in Brussels to DEA, Ottawa, 23 August 1968; The Times of London, "Internal issue at present, NATO states," The Globe and Mail, 22 August 1968, A9; Ottawa Bureau, "It'll set our relations back years says Sharp of Soviet invasion," Toronto Star, 21 August 1968, A1.

${ }^{93}$ LAC, RG 25, Vol. 8907, File 20, Part 4. Memorandum concerning the "Czechoslovak Situation - Special Task Force," from the Under-Secretary of State for External Affairs to All Divisions, 21 August 1968; LAC, RG 25, Vol. 8908, File 20, Part 11. Memorandum concerning the "Czechoslovak Task Force" from M.N. Bow to the Under-Secretary of State for External Affairs (through R.E. Collins), 4 September 1968.

94 See LAC, RG 25, Vol. 8907, File 20, Part 4. "Memorandum for European Division" from the UnderSecretary of State for External Affairs, 21 August 1968; LAC, RG 25, Vol. 8907, File 20, Part 4. Message regarding "Czechoslovakia," Telegram Number 3106, from British Foreign Office, London, to UK Mission, New York, 21 August 1968; Britain (page 54), Canadian Representatives Abroad and Representatives of Other Countries in Canada [Directory], DEA, February, 1967. Global Affairs Canada Digital Library, Jules Léger Library, Global Affairs Canada. http://www.gac.canadiana.ca; Mackie, Colin. "A Directory of British Diplomats," Colin Mackie's Website. Last updated 17 July 2018. $<$ www.gulabin.com> 
Council into session if others could not be persuaded to do so. ${ }^{95}$ Leaving the cabinet to the rest of its agenda, Sharp took the government's statement, approved with some changes, to meet the press. ${ }^{96}$

The statement described the invasion as "a flagrant breach of the principle of nonintervention to which the Soviet Union itself professes to subscribe." The Canadian government viewed the invasion with "shock and dismay," a "tragedy for all peoples who prize human freedom and national independence." "All Canadians," read the statement, "feel the deepest concern for the courageous people of Czechoslovakia in this hour of trial." It referenced Canada's ongoing consultations at the UN and NATO. It also highlighted how important it was that channels of negotiation remained open with the "ultimate goal of seeking a durable East-West accommodation." The occupation constituted "a serious setback to our rational dialogue." 97

Sharp's statement to the press was, according to media reports, a far more compelling performance than the one he had given the night before. Globe reporter Anthony Westell pointed out that it "bore little resemblance" to his "mild remarks" on Tuesday night. ${ }^{98}$ One reporter suggested that the strength of Canada's statement might signal that it was prepared to play a role in raising the issue at the Security Council, but Sharp declined to speculate. While Canada would certainly support such an initiative, he

95 LAC, RG 2, Series A-5-a, Vol. 6338. Cabinet minutes, 21 August 1968. 1-6;

96 LAC, RG 2, Cabinet minutes Series A-5-a, Vol.6338, 21 August 1968. 1-6; LAC, RG 25, Vol. 8907, File 20, Part 4. "Transcript of Press Conference Given by the Secretary of State for External Affairs. 21 August 1968."

${ }^{97}$ LAC, RG 25, Vol. 8907, File 20, Part 4. "Statement by the Secretary of State for External Affairs"; LAC, RG 2, Series A-5-a, Vol.6338. Cabinet minutes, 21 August 1968. 5.

98 The Globe's Scott Young wrote that by Wednesday, it was as if "somebody [had] told him: “"Hey, Mitch - when it rains on the day of the civil service picnic, that's disappointing. When somebody invades the other guy, you're shocked! Dismayed! All that jazz! Right?" See Anthony Westell, "Sharp hands Red diplomats Cabinet statement protesting against invasion," The Globe and Mail, 22 August 1968, A9; Scott Young, "Times when some words are not enough to describe one's feelings," The Globe and Mail, 22 August 1968, A7. 
said the choice of who might take the lead was a matter of whatever would prove to be the most effective. This, he said, "must over-ride any considerations of national prestige." 99

\section{Centre Stage at the UN}

Considerations of its own national prestige, alluded to in cabinet but dismissed at the press conference, was a part of Canada's response to the invasion. The embrace of a "vigorous" UN role is another difference in approach made apparent by the crisis. While Trudeau and Sharp had little appreciation for such undertakings, Cadieux, Ignatieff, and others at the DEA were significantly engaged in the process. As attentive as they were to the plight of Czechoslovakia, it mattered more that Canada was at the table.

Trudeau and Sharp did not share the same enthusiasm. Shortly after joining the Pearson cabinet, Trudeau had served as a delegate to the 1966 UN General Assembly. Peter Dobell observes that he "appears to have been impressed principally by the inefficacy of the organization and shocked by the contrast between the reality he observed and the image then current in Canada of the country's exaggerated influence within the UN. He saw how this image was nurtured by initiatives often of a purely procedural character, undertaken to satisfy public pressure for an active foreign policy." ${ }^{100}$ In his memoirs, Ignatieff describes Sharp as a less committed External Affairs Minister than Paul Martin, Secretary of State for External Affairs under L.B. Pearson. He writes that "if I had not enjoyed a different kind of relationship with Paul Martin and Mike Pearson, I might not have been so acutely aware of what I was missing." Martin would call him every morning "so we could discuss

\footnotetext{
99 LAC, RG 25, Vol. 8907, File 20, Part 4. "Transcript of Press Conference Given by the Secretary of State for External Affairs, 21 August 1968".

${ }^{100}$ Dobell, Canada's Search, 10-11.
} 
any issues that might come up that day in the Security Council." The routine of daily phone calls ended "abruptly" under Sharp and Trudeau. ${ }^{101}$

Dobell notes that, a year after the Czech crisis, Sharp gave a speech at the UN's $24^{\text {th }}$ General Assembly deriding it as a place where member nations "find debate to be a convenient substitute for action."102 Yet in response to the Soviet invasion of Czechoslovakia, this was exactly what Canada, and the Minister, proposed. When asked at the press conference if "words [were] going to be enough this time," Sharp noted that there was great concern to avoid the even worse tragedy of raising "false hopes." What had occurred after the invasion of Hungary in 1956 should not be repeated here. It was significant, he said, that Western countries were all acting with "great circumspection." While any action they might take in direct support of the Czechoslovakians was limited to "the force of world opinion," this, and "its effect on the people of Eastern Europe is not to be underestimated." He was sure that the invasion had dealt a blow to Soviet prestige. ${ }^{103}$

As he arrived home from Spain the day after the cabinet meeting, Trudeau told reporters that he was not looking to overdo Canada's expression of outrage at the UN over the invasion of Czechoslovakia. In reply to a question from reporters, he stated that, with Ambassador Ignatieff pressing Canada's position on the Security Council, there certainly was no need for him to go there personally. "We don't intend to plead it ad nauseam," he said. "It's a clear case of non-respect of the frontiers of a sovereign state. And our

${ }^{101}$ See Ignatieff, $235 ; 240-241$.

${ }^{102}$ Dobell quotes Sharp from the DEA, Statements and Speeches, 29 September 1969. See Dobell, Canada's Search, 133.

${ }^{103}$ LAC, RG 25, Vol. 8907, File 20, Part 4. "Transcript of Press Conference Given by the Secretary of State for External Affairs, 21 August 1968". 
instructions to our Ambassador were to state that case clearly." ${ }^{104}$ Others guiding Canada's activities in New York saw things differently. Trudeau had not been around the cabinet table the day before. Canada would be centre stage at the UN. According to his own account, Canada's UN Ambassador was about to become an "instant celebrity."105

The Canadian, US, and British ambassadors on the Security Council, as well as their Soviet counterpart, were all experienced players ready to play their part that summer. The Russian-born Ignatieff, by 1968 a veteran of External Affairs, describes the crisis in his memoirs as one of the few occasions "during Canada's two-year term on the Security Council when I was called upon to take any initiative." 106 Similarly, American George Ball characterized that August as one instance where "my tour as United Nations Ambassador was given a brief importance." Ball had occupied a variety of US government positions since 1933, including Under-Secretary of State in the Kennedy and Johnson administrations. ${ }^{107}$ Britain's Hugh Foot - Baron Caradon of St. Cleer - was himself almost four decades into his career as a diplomat. ${ }^{108}$ Their Soviet counterpart had Security Council experience dating back to the Korean War. ${ }^{109}$ In his memoirs, Ball describes Yakov Malik as "an old hard-line Stalinist" and "a fat, humorless apparatchik." 110 The Globe wrote that Ignatieff and Malik had "known each other for more than twenty years, and [had] a personal

${ }^{104}$ LAC, RG 25, Vol. 8907, File 20, Part 5. Policy Statement Distribution (PST 67),-Czechoslovak Situation, 22 August 1968; Lewis Seale, "Canada may stall any plans to cut troops," The Globe and Mail, 23 August 1968, A8.

${ }^{105}$ Ignatieff, Memoirs, 234.

${ }^{106}$ See Ignatieff, Memoirs, 3-29; 59-219; 231.

107 George Ball, The Past Has Another Pattern (New York: W.W. Norton \& Company, 1982), 5, 17-435; 436-438; 440; 443.

108 "Hugh Foot," Britannica Library Reference Center, Encyclopaedia Britannica, Ottawa Public Library, City of Ottawa. $<$ http//biblioottawalibrary.ca $>$

109 "Malik, Jacob A," Korean War Reference Library, Edited by Sonia G. Benson and Gerda-Ann Raffaelle, Vol. 2: Biographies. Detroit: UXL, 2002. 96-103, Gale Virtual Reference Library, 2014, Ottawa Public Library, City of Ottawa. $<$ http//biblioottawalibrary.ca $>$

${ }^{110}$ Ball, The Past, 440; 443. 
relationship which rest[ed] in part on Mr. Ignatieff's ability to josh with the Soviet diplomat in fluent Russian." 111

In his memoirs, Ignatieff writes that Canada was "once again" asked to take the lead by the Americans and the British at the UN. ${ }^{112}$ Yet Ball makes no mention in his memoirs of Ignatieff being designated as the "coordinator" of the Western response to the crisis. ${ }^{113}$ On the morning after the invasion, the US Ambassador happened to be in Washington conferring with the president. According to Ball's account, Johnson's instructions for Ball that morning were, "George, the matter's now in your hands; do what you have to do." Secretary of State Rusk interpreted for the ambassador: "[T]hat means put on your hawk's beak, go into the Security Council, and give the Russians hell."114

Although he suggests otherwise in his memoirs, Ignatieff, too, had his instructions. He observes of the time that "as far as I was concerned...I found myself without instructions from Ottawa, and I was left to explore for myself what our response might be to such events as the Soviet invasion of Czechoslovakia." ${ }^{\prime 15}$ In the case of Czechoslovakia, Ignatieff was less on his own than he makes it out to be in his autobiography. Sharp remained well-briefed, but it was Cadieux and his officials, rather than the minister, who were in touch with Ignatieff in New York.

In a manner that would have frustrated Trudeau, and ultimately to no avail, Western representatives at the UN contemplated how they would go about expressing their outrage against the invasion throughout the first day of Czechoslovakia's occupation. The hope

${ }^{111}$ Anthony Westell, "United Nations: The troubles that plague world prosecutors," The Globe and Mail, 24 August 1968, A9.

${ }^{112}$ Ignatieff, Memoirs, 228; 231-232.

${ }_{113}$ Ball, The Past, 440-443; Ignatieff, Memoirs, 231-232.

${ }^{114}$ Ball, The Past, 440.

${ }^{115}$ Ignatieff, 235; 240-241. 
was to avoid the appearance of a NATO/Warsaw Pact confrontation. Which group of countries should request the meeting and sponsor the resolution condemning the occupation, how the resolution should be worded, and which country would formally present it, was the subject of several behind-the-scenes meetings and much back-and-forth of instructions between governments and delegations before the actual meeting of the Security Council was called later in the day. Ignatieff kept Ottawa abreast of all developments and forwarded on his own prepared remarks for review and editing. Officials at home in turn followed up with instructions and edits, as well as with briefings for Sharp. Other ambassadors such as Robert Ford in Moscow continued to contribute comments and analysis. Ignatieff did play a central part in these consultations between UN delegations in New York, but was one of several other Western ambassadors, most notably Ball, Caradon, and Otto Borch of Denmark, fully engaged in the discussions. ${ }^{116}$

The Security Council meeting on the invasion, requested by Britain, Canada, Denmark, France, Paraguay, and the US, convened early on the evening of 21 August. As there was little doubt the Soviets would veto any Security Council resolution condemning the invasion, the wording of the resolution itself was the best opportunity that the West would have to, at the very least, send a message to the Soviets and those other Warsaw Pact nations who participated in the military action. Adding the item onto the agenda was a procedural matter; it could not be vetoed by the Soviets. That did not stop Ambassador Malik from trying. The Soviets, Malik warned, would not tolerate the attempts of

116 See LAC, RG 25, Vol. 8907, File 20, Part 4. "Memorandum for the Minister - Czechoslovakia at the United Nations" from the Under-Secretary of State for External Affairs (initialed "M.C."), 21 August 1968; Messages (2294; 2296-2297), Ignatieff to External Affairs, 21 August 1968; "Memorandum for the Minister - Czechoslovakia: Security Council" from the Under-Secretary of State for External Affairs (initialed "M.C."), 21 August 1968; Messages (1718-1719), from Ford, Moscow to External Affairs, 21 August 1968; LAC, RG 25, Vol. 8907, File 20, Part 5. Message (2306), Ignatieff to External Affairs, 22 August 1968; Ball, The Past, 440-441. 
"imperialistic reaction to intervene in the domestic affairs of Czechoslovakia." The Security Council, countered Ball, had rarely dealt with "a situation...in which the ugly facts of oppression [have] been written so large." Caradon added that "when we see what the Soviet Union can do to an ally, we shudder to think what it could do to anyone else." Ignatieff declared that the actions of the Soviets "infringe the most basic rights of sovereign states to decide their own affairs." The Council "must make clear," he argued, "where the weight of world public opinion stands on this issue." ${ }^{117}$ Once it became clear that he didn't have the votes to prevent the item's addition to the agenda, Malik moved to have his objection withdrawn. Ball was keen to force the vote anyway, to "demonstrate the strength on our side." In this procedural vote, the item was added, with all but the Soviet Union and Hungary in the affirmative. ${ }^{118}$

The "substantive discussion" continued into the night, but not before acting UN Czechoslovak Permanent Representative Jan Muzik, having received permission to participate in the proceedings without a vote, took his seat and spoke first. Ignatieff described it to Ottawa as a "moving address."119 "Rarely," wrote the Star's Robert Reguly, "has the UN seen such an electric moment as when Muzik confronted Soviet delegate Yakov Malik." Reguly reported that "Malik reddened, chewed on the temple of his glasses,

${ }^{117}$ LAC, RG 25, Vol. 8907, File 20, Part 4. "Memorandum for the Minister - Czechoslovakia at the United Nations" from the Under-Secretary of State for External Affairs (initialed "M.C."), 21 August 1968; Messages (2296 and 2303), Ignatieff to External Affairs, 21 August 1968; LAC, RG 25, Vol. 8907, File 20, Part 5. Messages (2305 and 2307), from PRMNY to External Affairs, 22 August 1968; AP-Reuters, "Soviet troops seize reform leaders, fire on Czechs in Prague streets; Didn't ask Reds, Prague tells UN," The Globe and Mail, 22 August 1968, A1; Ball, The Past, 440-441; "Threat of Soviet veto hangs over UN," Toronto Star, 22 August 1968. A1; A9.

${ }^{118}$ LAC, RG 25, Vol. 8907, File 20, Part 5. Messages (2305 and 2307), from PRMNY to External Affairs, 22 August 1968; AP-Reuters, "Soviet troops seize reform leaders, fire on Czechs in Prague streets; Didn't ask Reds, Prague tells UN," The Globe and Mail, 22 August 1968, A1; Ball, The Past, 440-441; "Threat of Soviet veto hangs over UN," Toronto Star, 22 August 1968. A1; A9.

${ }^{119}$ LAC, RG 25, Vol. 8907, File 20, Part 5. Messages (2305 and 2307), from PRMNY to External Affairs, 22 August 1968. 
and glowered" as Muzik "flatly repudiated the Soviet claim that Czechoslovak government and party leaders had asked the Russians to intervene with troops." ${ }^{120}$ Caradon derided the Soviet Ambassador for his suggestion that the invasion was carried out at the request of Czechoslovakian authorities, saying that the "lawful (Czechoslovak) authorities have spoken courageously for themselves in statements among the bravest known to history. How shocking that a small and brave people should be so bullied and so betrayed."121 Ignatieff issued a similar challenge to the Soviet portrayal of events. "Perhaps I might be permitted to remind the Ambassador of the USSR that fraternity has traditionally been associated with the concepts of liberty and equality," he said. ${ }^{122}$ After several hours of Cold War sparring, the Council agreed it would re-convene the following morning. ${ }^{123}$

Ignatieff was pleased that Canada and others had acted to bring the matter forward. He wrote to Ottawa that having the case "thoroughly aired and launching a public discussion" would almost certainly bring pressure in the long run on the Soviet Union and its associates in the invasion. ${ }^{124}$ Media coverage, however, reflected a different perception of such efforts at the UN - the "sad charade" of "pious resolutions" and helpless inaction in the face of superpower intransigence. The headline of The Globe's editorial the following morning was "A rape permitted." 125

${ }^{120}$ Robert Reguly, “'Soviets out to kill UN Czech debate'," Toronto Star, 22 August 1968. C1; C9.

${ }^{121}$ AP-Reuters, "Soviet troops seize reform leaders, fire on Czechs in Prague streets; Didn't ask Reds, Prague tells UN," The Globe and Mail, 22 August 1968, A1.

${ }^{122}$ LAC, RG 25, Vol. 8907, File 20, Part 5. Messages (2305, 2307, and 2311), PRMNY to External Affairs, 22 August 1968.

${ }^{123}$ LAC, RG 25, Vol. 8907, File 20, Part 5. Messages (2305, 2307 and 2311), PRMNY to External Affairs, 22 August 1968; AP-Reuters, "Soviet troops seize reform leaders, fire on Czechs in Prague streets; Didn't ask Reds, Prague tells UN," The Globe and Mail, 22 August 1968, A1; Anthony Westell, "United Nations: The troubles that plague world prosecutors," The Globe and Mail, 24 August 1968, A9.

${ }^{124}$ LAC, RG 25, Vol. 8907, File 20, Part 5. Messages (2306), Ignatieff to External Affairs, 22 August 1968.

${ }^{125}$ See "A rape permitted," The Globe and Mail, 22 August 1968. A6; "The Rape of a Nation: Stalin's spirit breathes again," Toronto Star, 21 August 1968, A6; "Let's not go back to the cold war." Toronto Star, 22 August 1968, A6. 
Additional tactical moves were determined which would ultimately elevate Canada's role in the West's overall response to the crisis. The plan all along had been to put forward the Security Council resolution condemning the Soviet Union for its invasion and calling for the withdrawal of its forces from Czechoslovakia. It was agreed that Denmark should introduce the resolution. The strategy assumed that the Soviets would veto the first resolution. The Americans proposed having a second, shorter resolution ready to submit which would call on the Secretary General to appoint a special representative to go to Prague. The British delegation prepared its wording. The envoy would be assigned to "take all possible steps to ensure the personal safety of the leaders of the Czechoslovak government and people and the humanitarian protection of the civilian population." 126

Canada was later asked by its allies to introduce this second resolution. Submitting the motion as a second resolution rather than as part of the original would prevent it from being subject to the first inevitable veto. Furthermore, if it was described as procedural and humanitarian rather than substantive, it was hoped that it could avoid a second veto. Vetoing a second resolution of a more humanitarian nature might be more difficult for the Soviets to stomach. Anticipating a second veto, however, the US proposed that yet another resolution, a clearly procedural one that was definitely not subject to a veto, be ready for introduction that would call for the immediate convening of an Emergency Special Session of the General Assembly. ${ }^{127}$

${ }^{126}$ LAC, RG 25, Vol. 8907, File 20, Part 5. Messages (2317 and 2321), Ignatieff to External Affairs, 22 August 1968; "Memorandum for the Minister - Czechoslovakia in the United Nations" from the UnderSecretary of State for External Affairs (signed "M.C." at end), 22 August 1968.

${ }^{127}$ LAC, RG 25, Vol. 8907, File 20, Part 5. Messages (2321, 2326 and 2330), Ignatieff to External Affairs, 22 August 1968; "Memorandum for the Minister - Czechoslovakia in the United Nations" from the UnderSecretary of State for External Affairs (signed "M.C." at end), 22 August 1968; LAC, RG 25, Vol. 8907, File 20, Part 6. "Memorandum for the Minister - Czechoslovakia at the United Nations" [II] from the 
The DEA envisioned for Canada a moment in the international spotlight. Officials recommended that the Minister approve the idea of Ignatieff moving the second resolution, but that as a consequence, Canada should be prepared to receive additional Soviet criticism. On the one hand, there was "no question" it would "draw the ire of the USSR and we will become a much more isolated target than has been the case so far." On the other hand, the humanitarian resolution "no doubt would be applauded by public opinion in Canada and the Western world.” Sharp approved. ${ }^{128}$

Canada was ready to be at the forefront when the first resolution was introduced. Thursday's Security Council meeting began with concern that the representative of Czechoslovakia, perhaps due to Soviet pressure, was no longer at the table. ${ }^{129}$ Speaking on behalf of Brazil, Britain, Canada, France, Paraguay, the US, and his own country, Denmark's Borch introduced the resolution condemning the military action, calling for the withdrawal of the invaders, and demanding an end to any acts that might result in further suffering or loss of life. ${ }^{130}$ Ignatieff spoke next. It was "intolerable...that the lawful authorities of Czechoslovakia should be subjected to the indignity of being removed forcibly from public office." He concluded:

The USSR and its collaborators in this adventure should not be allowed to think that the governments, Parliaments and peoples of the world can either ignore, or accept, or allow to die, the issue of Soviet-led intervention in the

Under-Secretary of State for External Affairs (signed "M.C." at end), 23 August 1968 (see also [I] from that same date cited below).

${ }^{128}$ LAC, RG 25, Vol. 8907, File 20, Part 5. Message (2326), Ignatieff to External Affairs, 22 August 1968; LAC, RG 25, Vol. 8907, File 20, Part 6. "Memorandum for the Minister - Czechoslovakia at the United Nations" [I] from the Under-Secretary of State for External Affairs (initialed "M.C." at end and signed, probably, by W.H. Barton), 23 August 1968 (judging from the letters in the signature, it appears that W.H. Barton of the Department's UN Division initialed it on Cadieux's behalf).

${ }^{129}$ LAC, RG 25, Vol. 8907, File 20, Part 5. Message (2324), Ignatieff to External Affairs, 22 August 1968; Anthony Westell, "Censure filibuster mounted," The Globe and Mail, 23 August 1968, A1.

${ }^{130}$ LAC, RG 25, Vol. 8907, File 20, Part 5. Message (2316), Ignatieff to External Affairs, 22 August 1968. 
affairs of Czechoslovakia. The facts speak for themselves and, like a jackin-the-box, once they have jumped out cannot easily be put back again. ${ }^{131}$

The Americans and the Soviets picked up where they had left off the night before. The kind of "fraternal assistance" that the Soviets and their allies offered Czechoslovakia was like that between Cain and Abel, Ball declared. Malik called the current Council effort a "repulsive comedy" in which the US had sought "second-rate NATO members" to come to its rescue. ${ }^{132}$ The Americans, Malik charged, were leading a counter-revolution in Czechoslovakia, one "acting upon instructions and directives from abroad, and playing the role of imperialist agents in that country." He added:

This explains why the representatives of the United States, with the assistance of the British, Canadian and other members of the military [sic] aggressive NATO bloc, which is directed against the Socialist community in Europe, has evinced such feverish activity in order to drag this question into the Security Council for discussion. ${ }^{133}$

The "Imperialists should not stick their noses into Socialist-Communist affairs," he warned. "Otherwise, they might lose them."134

Ignatieff continued to draw Malik's direct contempt. Countering procedural attempts by the Soviets and the Hungarians to delay the start of the next meeting, Canada joined the US in arguing that the world was watching as the USSR consolidated its occupation and that further debate should not be delayed. Algeria had argued on the Soviet side that "new elements" were now part of the situation. Ignatieff supposed that the "new elements" to which it was referring was a new government in Czechoslovakia being installed by force, one which would undoubtedly not wish the discussion to continue. This

\footnotetext{
${ }^{131}$ LAC, RG 25, Vol. 8907, File 20, Part 5. Message (2315), Ignatieff to External Affairs, 22 August 1968.

${ }^{132}$ LAC, RG 25, Vol. 8907, File 20, Part 5. Message (2324), Ignatieff to External Affairs, 22 August 1968.

133 Anthony Westell, “Censure filibuster mounted," The Globe and Mail, 23 August 1968, A1.

${ }^{134}$ LAC, RG 25, Vol. 8907, File 20, Part 5. Message (2324), Ignatieff to External Affairs, 22 August 1968.
} 
was the reason for Soviet delay tactics. "The government of Czechoslovakia is in the process of being changed - in the process of being changed today," said Ignatieff. "I do hope we are not going to wait until we receive representation of a new government which says, and confirms the statement, which the representative from Hungary has made, that the new government would of course not wish to continue this discussion." Malik argued that Canada's intervention clearly re-affirmed Western fears that counter-revolutionary forces in Czechoslovakia were "coming to the end of their tether." Caradon's motion setting an earlier resumption of the debate for later that day was adopted. ${ }^{135}$

Consultations continued throughout the afternoon. Ignatieff informed Czechoslovak Permanent Representative Muzik of the plan for the second resolution. While he refrained from commenting on its text, Muzik said it was important that the Council's discussion of the crisis be kept alive until the arrival of their Foreign Minister, who was expected to be there the next day. In addition, Ignatieff reported to Ottawa, Muzik thanked him for all that Canada was doing. ${ }^{136}$

When the debate resumed that night, Muzik re-appeared before the Security Council and told it that Czechoslovakian Foreign Minister Dr. Jiri Hajek was on his way to New York to "explain the position of my country in full detail."137 Another Soviet filibuster set off more procedural wrangling between Ball and Malik. To Ottawa, Ignatieff

${ }^{135}$ LAC, RG 25, Vol. 8907, File 20, Part 5. Messages (2315, 2324, and 2334), Ignatieff to External Affairs, 22 August 1968.

${ }^{136}$ See LAC, RG 25, Vol. 8907, File 20, Part 5. Messages (2326 and 2330), Ignatieff to External Affairs, 22 August 1968; LAC, RG 25, Vol. 8907, File 20, Part 6. "Memorandum for the Minister - Czechoslovakia at the United Nations" [I] from the Under-Secretary of State for External Affairs (signed "M.C." and initialed, probably, by W.H. Barton), 23 August 1968; "Memorandum for the Minister - Czechoslovakia at the United Nations" [II] from the Under-Secretary of State for External Affairs (initialed and signed "M.C." at end), 23 August 1968.

${ }^{137}$ LAC, RG 25, Vol. 8907, File 20, Part 5. Messages (2330 and 2331), Ignatieff to External Affairs, 22 August 1968; Anthony Westell, "Censure filibuster mounted," The Globe and Mail, 23 August 1968, A1. 
described the debate that night as "polemical," laying principal responsibility for this at Ball's feet. The US Ambassador, he observed, was no doubt playing to his own national audience, including those attending the 1968 Democratic National Convention meeting in Chicago that same week. Ignatieff reported that "it was in these circumstances that I intervened at the suggestion of the [Security Council] president (given me privately) to move that we proceed to the vote." Finally, around 3:00 a.m. Friday morning, the Soviet Union's filibuster ran out of steam. The Council voted to condemn its invasion of Czechoslovakia and call for its withdrawal. The inevitable Soviet no vote vetoed the resolution's adoption. ${ }^{138}$

It was now time for Canada to earn the full theatrical wrath of the Soviet Union. Ignatieff proceeded to move the second resolution. In light of the Soviet veto of the first resolution, he began, "I believe that we must briefly consider, before we adjourn, what further action the Security Council should endeavour to take in view of the continuing seriousness of the situation in Czechoslovakia." Malik did not at first react, choosing instead to rail further against Ball for his denouncement of the Soviet veto. Ignatieff reported that "[t]he exchange between Malik and Ball was [as] sharp and reminiscent of the Cold War as any that has been heard in the Council since Korea." Then Malik addressed Ignatieff. The second resolution was an "imperialist design" meant to circumvent the Soviet objection to any substantive proposal. He "glared across the table" and said:

I consider the proposal of the Canadian delegation as a new trick by the NATO countries in this dirty, shoddy business. He is the main spokesman and representative of Anglo-American circles. Having failed in their attempt to impose their resolution on the Security Council, they now resort

${ }^{138}$ LAC, RG 25, Vol. 8907, File 20, Part 5. Message (2330), Ignatieff to External Affairs, 22 August 1968; Anthony Westell, "Censure filibuster mounted," The Globe and Mail, 23 August 1968, A1; Anthony Westell, "United Nations: The troubles that plague world prosecutors," The Globe and Mail, 24 August 1968, A9. 
to other tricks. They are trying to drag the Secretary-General of the United Nations into the dirty business of intervention into the affairs of a Socialist state and the common cause of fraternal Socialist countries.

Malik warned the resolution's co-sponsors that he viewed it as substantive and that they would not be able to bypass the Charter. ${ }^{139}$

Canada's delegation in Washington reported that, while at least one senior State Department official had commented very favourably on the Canadian presentation that night, they had also heard expressed within the Department some disappointment with Ball's performance. The enormity of the Soviet action was so clear that the issue was only “obscured by dredging up Cold War issues of the past twenty years." ${ }^{140}$ In his brief to Sharp about the debate, Cadieux reiterated that Canada was now front and centre in the West's reaction to the crisis. Canadians tuned into the news would be taking notice of the government's actions in New York. "Mr. Ignatieff, pursuant to the authority you gave him last evening, presented [the second resolution]," wrote the Under-Secretary. "As you may have heard on the radio, Mr. Ignatieff is accused by Mr. Malik of being the spokesman of the Anglo-American camp."141

Newspapers like the Star joined in the drama. "Canada demands UN rescue deposed Czechs" was its headline later that day. Canada had "outraged" Russia, accused by the superpower of being "a US lackey" up to a "dirty trick," a "tool of the "NATO clique" in the thick of its "evil designs."142 The Star argued that, while "no other power

\footnotetext{
${ }^{139}$ LAC, RG 25, Vol. 8907, File 20, Part 5. Messages (2330 and 2332), Ignatieff to External Affairs, 22 August 1968; Anthony Westell, "United Nations: The troubles that plague world prosecutors," The Globe and Mail, 24 August 1968, A9; Ignatieff, Memoirs, 232.

${ }^{140}$ LAC, RG 25, Vol. 8907, File 20, Part 5. Message (3089), Canadian Embassy, Washington, D.C. to External Affairs, 22 August 1968.

${ }^{141}$ LAC, RG 25, Vol. 8907, File 20, Part 6. "Memorandum for the Minister - Czechoslovakia at the United Nations" [II] from the Under-Secretary of State for External Affairs (initialled and signed "M.C." at end), 23 August 1968.

142 Robert Reguly, "Canada demands UN rescue deposed Czechs," Toronto Star, 23 August 1968. A1.
} 
or combination of powers can stop [the USSR] short of launching a suicidal war," the Soviets could be "embarrassed" and "diplomatically...humiliated and kept on the defensive." Reaction to the invasion - both "popular resistance" in Czechoslovakia and the rest of the world's "moral indignation" - might "influence them to mitigate their crime."143 In this, Canada was seen to be doing its part. As one DEA assessment of Canada's UN initiatives argued, they had at the very least provided "a platform for the Czech representative." ${ }^{144}$

On 23 August, the government disregarded the Opposition's calls for an earlier reconvening of Parliament, made more urgent by the Czechoslovakian crisis. Perhaps given the relationship between its new and former leaders, comment from the Conservative opposition on the invasion's implications was not entirely united. Stanfield, speaking from Laval University where he was taking French classes, said that the invasion was "a reminder of Russian ruthlessness." "Things," he said, "have not changed much since Stalin's times." Contrary to former leader Diefenbaker's position, Stanfield indicated that he too was in favour of a review of Canada's contribution to NATO in Europe and did not know "if it should be maintained in the present form." 145 Through a spokesman, Trudeau answered Stanfield on Czechoslovakia by saying that "if the Conservative Leader has proposals or thoughts on new Canadian action, he would be glad to hear from him."146

That action was set to resume in New York, with Canada continuing to be directly targeted by the Soviets. Gathering for an hour-and-a-half under Canadian chairmanship,

143 "Even a superpower can be embarrassed," Toronto Star, 23 August 1968. A6.

${ }^{144}$ LAC, RG 25, Vol. 8907, File 20, Part 5. "Memorandum for the Minister - Czechoslovak Situation: Canadian Policy" from the Under-Secretary of State for External Affairs (signed "M.C." at end), 22 August 1968.

${ }^{145}$ Quebec Bureau. "Stanfield cites Red invasion in seeking Parliament's recall," The Globe and Mail, 23 August 1968, A8.

${ }^{146}$ Lewis Seale, "Cabinet meets." The Globe and Mail, 24 August 1968, 4. 
the so-called Group of Eight sponsors of the second resolution had continued its consultations that day. Tactically, much depended upon the arrival time of Czechoslovakian Foreign Minister Hajek, who was understood to be on his way from Vienna. ${ }^{147}$ Malik resumed his verbal assault on Canada as debate on the Canadian resolution resumed that Friday night. Repeating his attack on Canada for representing the interests of the "Western imperialists," he observed that "[b]ehind the representatives of Canada one can see the looming shadow of the representatives of the United States and the more attenuated shadow of the United Kingdom."148 Ignatieff replied:

Mr. President, I have no intention of following the distinguished representative of the USSR, whose personal qualities I respect, in an exchange of incivilities and accusations....I will, however, say this on behalf of the Canadian position: 1) We have scrupulously avoided interference, of any kind, in the developments in Czechoslovakia; 2) we have no intention in promoting unrest in Central Europe or anywhere else by efforts to influence the type of government which exists there. What is at issue here is not whether Czechoslovakia should be a communist state; the issue has been, and continues to be, the inadmissibility of intervention in the internal affairs of any state by any other state...

Canada, he said, was "acting as a loyal member of the Security Council" and the intent of the second resolution was strictly humanitarian. ${ }^{149}$ Caradon argued that "we are concerned with the fate of brave men" and "we shall not be content until we get an answer."150

What Western delegates did not know at the time was that Dubcek was to be flown to Moscow from captivity in Slovakia the next day to take part in discussions with the Soviets. ${ }^{151}$ Malik provided his counterparts with assurances that talks were already

${ }^{147}$ LAC, RG 25, Vol. 8907, File 20, Part 6. Message (2340), Ignatieff to External Affairs, 23 August 1968.

148 Anthony Westell, "Security Council adopts wait-and-watch position," The Globe and Mail, 24 August 1968, A1.

${ }^{149}$ LAC, RG 25, Vol. 8907, File 20, Part 6. Message (2344), Ignatieff to External Affairs, 23 August 1968.

${ }^{150}$ Anthony Westell, "Security Council adopts wait-and-watch position," The Globe and Mail, 24 August 1968, A1.

${ }^{151}$ Ignatieff, Memoirs, 232; Vincent Buist, "Gunfire, phone wires ripped out and a cold meal: How Russian soldiers hustled a handcuffed Dubcek out of Prague," The Globe and Mail, 29 August 1968, A1; Tad 
proceeding with Czechoslovakian President Ludvik Svoboda in Moscow. It was agreed to adjourn until Saturday. ${ }^{152}$ Chargé d'affaires Cole reported to Ottawa that the presidential flag over Prague Castle had flown on Friday until about 10:30 a.m. local time. It had been announced that a delegation led by Svoboda was journeying to Moscow to negotiate on Russian soil what he had not so far been successful at doing at home: a settlement preserving the essence of democratization in Czechoslovakia. Its citizens, Cole observed, were not optimistic. A General Strike had been held that day, resulting in an intensification of gunfire and reports of more killings. One estimate had put the number of dead since the invasion at more than one hundred. Clandestine radio operators continued to frustrate efforts to shut them down. ${ }^{153}$

That night, First Secretary Alois Drhlik of the Czechoslovakian Embassy in Ottawa called the DEA to inform the Canadian government about the Svoboda delegation's trip to Moscow. ${ }^{154}$ Svoboda had flown to Moscow and been received by the Soviets, the Globe reported, "with full honours." 155 In his 1989 memoirs, however, Ambassador Ford describes the "farce" of Svoboda's reception by Brezhnev at the airport as something the Soviet leader went through in order to "maintain the fiction of normal relations." dispatch to Ottawa at the time, Ford depicted the arrival, broadcast on Moscow television,

Szulo and Clyde Farnsworth, "Seven days that shook Czechoslovakia: quislings' failure and secret congress," The Globe and Mail, 4 September 1968. A3.

152 Anthony Westell, "Security Council adopts wait-and-watch position," The Globe and Mail, 24 August 1968, A1.

${ }^{153}$ LAC, RG 25, Vol. 8907, File 20, Part 6. Message (811), Cole to External Affairs, 23 August 1968.

${ }^{154}$ LAC, RG 25, Vol. 8907, File 20, Part 7. Message regarding the "Czech Situation" (Number S-904), J.G.H. Halstead, External Affairs, to Prague, 26 August 1968.

${ }^{155}$ Anthony Westell, "Security Council adopts wait-and-watch position," The Globe and Mail, 24 August 1968, A1.

${ }^{156}$ Robert Ford, Our Man in Moscow: A Diplomat's reflections on the Soviet Union. (Toronto: University of Toronto Press, 1989), 203. 
as a "tragi-comic scene" in which the Head of State of the recently invaded country was "solemnly bussed on both cheeks" by the First Secretary of the invading country. ${ }^{157}$

Events in Moscow would have a bearing on Czechoslovakia's next move in New York. During the Security Council meeting on Friday night, it was confirmed that Hajek would not be appearing that evening, but the Czechoslovaks were clearly interested in ensuring that a forum remained open to express their views should Hajek decide that he would attend Saturday's meeting. About fifteen minutes before the meeting's adjournment, members of the Canadian delegation spoke with a Czechoslovakian representative outside the Council chamber. They assured him that, with or without a vote on the second resolution that evening, the Council would remain seized of the Czechoslovakian crisis. ${ }^{158}$

According to Cole, Czechoslovaks remained skeptical about the Svoboda talks and reports of Dubcek's re-emergence encountered similar skepticism. He described to Ottawa a "wave of pessimism" sweeping across Prague after another sleepless night that saw some of the heaviest gunfire since the occupation had begun. Cole feared that the campaign of passive resistance would soon give way to widespread violence if the country, particularly its less temperate youth, did not receive "some encouraging[,] believable news." ${ }^{159}$ Hajek was also waiting for such news. Ignatieff reported to Ottawa that the Canadian delegation received confirmation by phone on Saturday morning that Hajek wished to speak at the upcoming Security Council meeting. ${ }^{160}$

Ignatieff described to Ottawa the Soviet delegation's efforts outside the Council chamber to dissuade their Czechoslovak counterparts from going ahead with the Hajek

\footnotetext{
${ }^{157}$ LAC, RG 25, Vol. 8907, File 20, Part 7. Message (1753), Ford to External Affairs, 24 August 1968.

${ }^{158}$ LAC, RG 25, Vol. 8907, File 20, Part 6. Message (2350), Ignatieff to External Affairs, 23 August 1968.

${ }^{159}$ LAC, RG 25, Vol. 8907, File 20, Part 7. Message (822), Cole to External Affairs, 24 August 1968.

${ }^{160}$ LAC, RG 25, Vol. 8907, File 20, Part 7. Message (2354), Ignatieff to Ottawa, 24 August 1968.
} 
speech as the Security Council meeting began. ${ }^{161}$ At the same time, the Soviets attempted to delay the proceedings inside while Hajek, in Ignatieff's words, "sat stolidly awaiting an opportunity to speak." Ignatieff reported that the Soviets had hoped to drag out the meeting long enough that Hajek might either change his mind about speaking or receive a message from Svoboda in Moscow not to speak. Such an instruction apparently had arrived, he wrote, but not in time. The Czechoslovakian delegation later denied receiving this message. Hajek readied to address the Council over the Soviets' obvious objections. ${ }^{162}$

Ignatieff reported that Hajek opened his 35-minute speech by explaining that he was "speaking with emotion, sadness, and regret." The Foreign Minister said that there was no justification for the unilateral occupation of his country, the USSR and its allies had not been asked to intervene, and that there was no danger of a counter-revolution in Czechoslovakia. Ignatieff quoted him directly: "Under Dubcek the Communist Party had gained such natural authority as hardly ever before, resulting in a spontaneous powerful stream of Socialist patriotism." Ignatieff's summary went on. Despite the "insensitive and illegal occupation," Hajek stated that his government and the Czech people "still maintained the friendliest intentions towards the USSR and other Socialist allies."163

The Star wrote afterwards that Hajek's “quiet, scholarly and carefully understated disquisition shattered into a thousand tiny fragments" the Soviet position. Malik replied by reading a statement which "woodenly restated the thesis Hajek had refuted." 164 The paper observed that the exchange between the representatives of two Eastern Bloc nations spoke

\footnotetext{
${ }^{161}$ LAC, RG 25, Vol. 8907, File 20, Part 7. Message (2355), Ignatieff to Ottawa, 24 August 1968.

${ }^{162}$ LAC, RG 25, Vol. 8907, File 20, Part 7. Messages (2354-2357; 2360), Ignatieff to Ottawa, 24 August 1968.

${ }^{163}$ LAC, RG 25, Vol. 8907, File 20, Part 7. Message (2357), Ignatieff to Ottawa, 24 August 1968.

${ }^{164}$ UPI-Special, “Czechs at UN don't want to rock Kremlin boat,” Toronto Star, 26 August 1968, A1; A4.
} 
for itself. There was no need for any Western delegate to "embroider the situation." It was "one of the most quietly dramatic in the UN's 23-year history.",165

After the speech, the Star noted, Hajek "thanked Canada and other nations for opening up a forum and keeping it open in the face of bitter, but eventually futile, Russian roadblocks."166 Ignatieff observed that it was now up to the Czechoslovaks to decide on the usefulness of any further Security Council meetings regarding the crisis. Hajek had said that the Moscow talks were "continuing in a frank and comradely atmosphere" and that "Socialist problems could be settled without foreign interference." Ignatieff reported that the "original initiative of convening the Security Council and the subsequent debate have already achieved their purpose to a large extent." The Canadian resolution could be "maintained from day to day" should it be required to put pressure on the Soviets, but developments might make it unnecessary. ${ }^{167}$ Hajek told reporters that while "he hoped the Council would keep the situation under review," a favourable climate could be "created more by silence than by good speeches." 168

Further behind-the-scenes talks continued that weekend. Canada chaired another meeting of the Group of Eight on Monday morning. The Council was scheduled to resume debate on the Canadian resolution, but as its sponsors continued to await word on the Moscow talks, it was agreed that the session ought to be cancelled, and no date was set for another meeting. That evening, the Czech delegation announced that it would boycott

\footnotetext{
${ }^{165}$ UPI-Special, “Czechs at UN don't want to rock Kremlin boat,” Toronto Star, 26 August 1968, A1; A4. 166 “Apologetic Czech at UN says: Ivan, go home.” Toronto Star. 26 August 1968. A4.

${ }^{167}$ LAC, RG 25, Vol. 8907, File 20, Part 7. Messages (2355 and 2357), Ignatieff to Ottawa, 24 August 1968.

168 Anthony Westell, "West to chart course on Prague crisis," The Globe and Mail, 26 August 1968. A8.
} 
further meetings of the Council on the crisis. ${ }^{169}$ Ottawa prepared Minister Sharp for an impending announcement from Moscow. ${ }^{170}$

Word came from TASS on Tuesday morning that an agreement had been reached in Moscow. ${ }^{171}$ The Czechoslovakian delegation had flown home from Moscow early that morning. It had been agreed that occupying military forces in Czechoslovakia would slowly be withdrawn and Dubcek would remain his country’s leader. ${ }^{172}$ In an address later that day, Dubcek told his people that Czechoslovakians would resume governing their own country. Such government, however, would now "take place in a situation and a reality not dependent on our will only." 173 The Globe reported that thousands of Czechoslovakians marched in the streets of Prague that night, believing they had been "sold out." 174 Cole's dispatches to Ottawa described the same disillusionment. ${ }^{175}$

The clandestine radio stations in Czechoslovakia which had sprung up within hours of the invasion were now, "one by one," going off the air. ${ }^{176}$ As the final situation report

${ }^{169}$ LAC, RG 25, Vol. 8907, File 20, Part 7. Messages (2360-2361; 2376), Ignatieff to External Affairs, 24 August 1968; "Memorandum for the Minister - Czechoslovakia at the United Nations" from the UnderSecretary of State for External Affairs (initialed "M.C." at end), 26 August 1968; LAC, RG 25, Vol. 8907, File 20, Part 8. Messages (2382-2383; 2388), Ignatieff to External Affairs, 27 August 1968.

${ }^{170}$ See LAC, RG 25, Vol. 8907, File 20, Part 7. "Memorandum for the Minister - Czechoslovakian Situation" from the Under-Secretary of State for External Affairs (initialed "M.C." at end), 26 August 1968 [attached to this document is: "Czechoslovak Negotiations - Talking Points," 26 August 1968]; "Memorandum for the Minister - Czechoslovak Situation: Kiesinger's Proposal" from the Under-Secretary of State for External Affairs (signed "M.C." at end), 26 August 1968; Message (2369), from Canadian Permanent Mission at the UN to External Affairs, 26 August 1968; LAC, RG 25, Vol. 8907, File 20, Part 8. Memorandum on the "Czechoslovak Situation - Situation Report - Tuesday, August 27, 1968." 27 August 1968; LAC, RG 25, Vol. 8907, File 20, Part 9. Message (2086), Campbell at NATO Council in Brussels to External Affairs, 28 August 1968.

${ }^{171}$ See LAC, RG 25, Vol. 8907, File 20, Part 8. Memorandum on the "Czechoslovak Situation - Situation Report - Tuesday, August 27, 1968." 27 August 1968; "Czechoslovakia Situation,” Press Release, DEA, 10:30 a.m., 27 August 1968.

${ }^{172}$ New York Times and AP, "Talks ended, TASS reports. Dubcek to retain post, Czechs in Moscow say," The Globe and Mail, 27 August 1968, A1.

${ }^{173}$ Reuters, “... and by Alexander Dubcek,” The Globe and Mail, 28 August 1968, A4; Reuters, “...by Ludvik Svoboda," The Globe and Mail, 28 August 1968, A4.

${ }^{174}$ New York Times and Reuters, “'We've been sold out,' Czechs cry as Dubcek makes plea for support: Press censorship re-imposed today," The Globe and Mail, 28 August 1968. A1.

${ }^{175}$ LAC, RG 25, Vol. 8907, File 20, Part 8. Messages (851; 858), Cole to External Affairs, 27 August 1968.

176 "Stations give up," The Globe and Mail, 30 August 1968, A1. 
issued under the auspices of the DEA's Czechoslovak Task Force put it at the end of the week: a "long hard winter seems to be in store for the people of Czechoslovakia." In what the report described as a "last gasp of freedom of the press," the Czechoslovak Writers' Union Journal declared that the Soviet Union had forfeited the right to a leading role in the Communist world, but warned its oppressors that "thoughts cannot be shot dead." Nevertheless, the report observed that Czechoslovakians were "apparently heeding the advice of their leaders and accepting the reality of Russian occupation."177

A week had passed since the cabinet's first meeting to discuss the situation in Czechoslovakia. Czechoslovakia remained on its agenda, but with much less urgency. ${ }^{178}$ The Canadian resolution before the Security Council in New York would stay on its agenda as the starting point for any revival of debate, and in the days to come, Canada's consultations on the crisis would continue. Ignatieff, meanwhile, would relinquish the chairmanship of the Group of Eight when, at the end of the month, Canada was due to take over the presidency of the Security Council. ${ }^{179}$

Debate at the Security Council had, as the Canadian statement issued in response to the Moscow agreement asserted, "helped to focus attention" on the Soviet Union's contraventions of the UN Charter. In the coordinating role it had played at the UN, the Canadian government had possibly contributed to Dubcek's safe return to Prague - or so it could at least claim:

The main point of [the Canadian] resolution was the release and safety of Czechoslovak leaders. Inasmuch as these leaders have been in a position to negotiate with the Soviet Union and now have returned to Czechoslovakia

${ }^{177}$ LAC, RG 25, Vol. 8907, File 20, Part 10. "Czechoslovak - Situation Report.” 30 August 1968.

${ }^{178}$ LAC, RG 2, Series A-5-a, Vol. 6338. Cabinet minutes, 28 August 1968. 1-2; 6; 30 August 1968. 1-2; 7.

${ }^{179}$ LAC, RG 25, Vol. 8907, File 20, Part 8. Message (2382, 2394, and 2398) from Canadian Permanent Mission at the UN to External Affairs, 27 August 1968; the delegation's subsequent messages can be found in LAC, RG 25, Vol. 8907, File 20, Parts 8-10; LAC, RG 25, Vol. 8908, File 20, Parts 11-18. 
to resume their functions under the Czechoslovak Constitution, the immediate objective of the draft resolution would appear to have been achieved. ${ }^{180}$

Editorial opinion at home was less impressed with the effort. The Star's William White, for example, argued that " $[\mathrm{u}]$ naided, apart from an eruption of tortured sympathy around the world," the Czechoslovak people had "fought bullets with flags, aggression with truth, and tanks with the weight of their own bodies." 181 His paper, in a separate editorial, observed that "[t]he people of Czechoslovakia, defended only by their united moral force, have won an astonishing if heavily qualified victory against the oppressive might of the Soviet Union." Theirs had been "a near-perfect display of passive resistance."182 The Globe wrote that the "abortive" UN Security Council debate had once again revealed its "impotence to deal with an offence by one of the major powers." 183

As "impotent" as the effort may have seemed, Canada's role in it had ruffled some superpower feathers. One more Soviet outburst put Canada back in the spotlight in early September. Canadian officials once again basked in the international attention. The Soviets launched a propaganda tirade against Ignatieff in Pravda, calling him a "marksman" for the West who was "plotting to renew discussion of the Czechoslovak crisis at the UN." Sharp came to Ignatieff's defence. Canada being "singled out for [such] abuse" by the Soviets only indicated how effective the country had been at "helping to bring the pressure of world opinion to bear against the Soviet use of force in Czechoslovakia." Such statements were "a clear demonstration of the sensitivity of the USSR to world reaction

${ }^{180}$ LAC, RG 25, Vol. 8907, File 20, Part 8. "Soviet-Czechoslovak Agreement," Press Release, DEA, 5:00 p.m., 27 August 1968.

${ }^{181}$ William White, "Courage of Czech nation shines in Red nightmare," Toronto Star, 28 August 1968, A8.

182 "Czechoslovakia: Chains or qualified freedom?" Toronto Star, 28 August 1968, A6.

183 "Self-interest comes first," The Globe and Mail, 27 August 1968, A6. 
against their invasion." Sharp added that "[t]he Soviet attack on Mr. Ignatieff personally is one more demonstration of the weakness of the Soviet case, as the USSR is well aware that he was acting at all times on the instructions of his government." ${ }^{184}$ It is in regards to news coverage all over Canada of the 4 September Pravda attack against him that, as noted earlier, Ignatieff reflects in his memoirs about his moment of national stardom. ${ }^{185}$

The Globe reported comments towards the end of the crisis by Charles Gibbings, president of the Saskatchewan Wheat Pool. While he understood the government's good intentions, "Canada's sponsoring of two resolutions against Soviet intervention in Czechoslovakia in the United Nations Security Council [had] not helped sell Prairie wheat to the Soviet Union." 186 The DEA's UN efforts had not been undertaken entirely in Canada's own self-interest, but much of it was driven by a desire to appear relevant on the world stage. This had not come from Canada's new prime minister. He remained unconvinced of the DEA's utility in furthering the country's interests internationally.

\section{Trudeau, Cadieux, NATO, and Détente}

Czechoslovakia would confirm that the new prime minister saw the improvement of East-West relations as a goal in Canada's national interest. Marcel Cadieux was similarly inclined, but the two differed on the pace of change that might bring that about in particular, Canada's future within NATO. The invasion of Czechoslovakia sheds further light on their disagreement.

\footnotetext{
${ }^{184}$ Canadian Press-Reuters, “'Characteristic of propaganda machine': Sharp rejects Soviet charge Ignatieff plotting at UN," The Globe and Mail, 5 September 1968, A4.

185 Ignatieff, Memoirs, 234.

186 E.N. Davis, "Criticism of Soviet hurt sales," The Globe and Mail, 12 September 1968, B5.
} 
Canada's policy throughout the crisis had emphasized keeping the channels of negotiation open in pursuit of "our ultimate goal of seeking a durable East-West accommodation." 187 While sympathetic to Czechoslovakia's plight, of greater concern for Canada was its own longer-term security. It was not going to let the invasion jeopardize this. The morning after the invasion, Cadieux outlined the essential framework of Canada's approach to the crisis, pointing to the "conflicting" aspects of the required response. "[T]he situation," he wrote, "seemed to call for a quick and strong condemnation." However, "we had to bear in mind that progress would only be made as a result of a continuing dialogue with the communist countries." It was essential "in anything we did not to take steps which would make further progress more difficult." 188

Sharp re-iterated to the press the government assertion that the invasion was a setback for East-West relations, but that "I, for one hope that the dialogue can continue." It was "of the utmost importance for the future that we should not despair of the possibilities of promoting peaceful relations between the Soviet Union and the NATO alliance":

The significance of these events seems to be that the Soviet Union is very reluctant to see freedom proceed more quickly in satellite countries than in the Soviet Union itself. But it must be the hope of the world that we will see greater freedom for all these people and that it should be our endeavor to try to promote good relations between the East and the West, notwithstanding the fact that we condemn this particular action as all free people must condemn it. ${ }^{189}$

Cadieux provided Sharp with a paper that day on policy questions raised by the Soviet intervention. The paper, which would also provide the basis for guidelines subsequently issued to concerned departments and missions abroad, captured what the

${ }^{187}$ LAC, RG 2, Series A-5-a, Vol. 6338. Cabinet minutes, 21 August 1968. 5.

${ }^{188}$ LAC, RG 25, Vol. 8907, File 20, Part 4. "Memorandum for European Division" from the Under-Secretary of State for External Affairs, 21 August 1968.

${ }^{189}$ LAC, RG 25, Vol. 8907, File 20, Part 4. "Transcript of Press Conference Given by the Secretary of State for External Affairs, 21 August 1968". 
Under-Secretary and his officials had identified as the essential "dilemma" posed by the invasion. As Canada's undertaking at the UN was demonstrating, appearances mattered. "[T]he Government would not wish to appear, either to the Russians or to the Canadian people, to endorse the Soviet action or even to acquiesce in it," wrote Cadieux. "On the other hand it would not be in the interests of Canada or the free world if we put an end from our side to all forms of dialogue and practical cooperation with them, since we continue to believe that this is the only course that can lead eventually to an East-West accommodation." The core recommendation was to seek a "judicious balance between the stick of our disapproval and the carrot of further cooperation." 190

Trudeau arrived home early from Spain two days into the Soviet occupation of Czechoslovakia. ${ }^{191}$ As he stepped off an air force plane in Ottawa, he seemed less interested in prosecuting the current crisis than in signaling a longer-term vision of a world that could "evolve" beyond the animosities of the Cold War era. ${ }^{192}$ He was not speaking to just one superpower, but both. A lecturing Canadian prime minister put on record some of the vocabulary the world might later need to bind itself together in new ways. Appearing "tanned but weary," he answered reporters' questions about the invasion:

It's obvious that the Soviet Union is still basing itself on that kind of partition which was set up back in Tehran and Cairo after and during the Second World War. We are hoping that Europe and the world will evolve beyond this political participation of spheres of influence and our foreign

190 See LAC, RG 25, Vol. 8907, File 20, Part 5. "Memorandum for the Minister - Czechoslovak Situation: Canadian Policy" from the Under-Secretary of State for External Affairs (signed "M.C." at end), 22 August 1968; "Memorandum for the Minister - Resume of the Czechoslovak Situation" from the UnderSecretary of State for External Affairs (signed "M.C." at end), 22 August 1968; Message (No. G.25), regarding the "Czechoslovak Situation," External Affairs to Canadian permanent delegation, NATO Council in Brussels (cc'd to other Missions), 22 August 1968; LAC, RG 25, Vol. 8907, File 20, Part 6. "Czechoslovak Situation: Canadian Interests." 23 August 1968; "Czechoslovakia: Situation Report," 23 August 1968; Message (No. G.28) regarding the "Czechoslovak Situation," External Affairs to Canadian permanent delegation, NATO Council in Brussels (cc'd to other Missions), 23 August 1968.

${ }^{191}$ Lewis Seale, "Canada may stall any plans to cut troops," The Globe and Mail, 23 August 1968, A8.

192 Trudeau's use of the word "evolve" is part of the larger quotation that follows. See LAC, RG 25, Vol. 8907, File 20, Part 5. Policy Statement Distribution (PST 67) - Czechoslovak Situation, 22 August 1968; 
policy review and our thinking in international affairs is an attempt to go beyond that. Apparently the Soviets by their action are still trying to bind the political and social, I mean the economic and social fate of Europe to political concepts developed 20 years ago, and to me this is slow thinking. ${ }^{193}$

The invasion would not in Trudeau's view stand as a singular reason for Canada to maintain its NATO troop levels in Europe, nor stop Canada from pursuing a new foreign policy designed to evolve the world beyond political participation in spheres of influence. In fact, he said, "I suppose it shows that the [foreign policy] review is even more necessary than it was before." Nuclear deterrence, he told reporters, made conventional forces increasingly irrelevant. In his repartee with journalists, Trudeau asked:

What forces are you referring to - ground forces? Is the balance of nuclear deterrents strong enough? I don't think any specific military course follows obviously from this action in Czechoslovakia on our side except that we do want to stand pat until our review is finished. ${ }^{194}$

Answering another query, he said there was no need for a meeting of NATO leaders on the invasion. "The way in which NATO develops may be conditioned by this happening within the Warsaw Pact countries, but I don’t think our actions are coordinated with theirs." 195

Officials at the DEA distributed a transcript of the press conference as a policy statement. ${ }^{196}$ Trudeau's remarks had not veered far from Canada's already articulated position on the invasion and emerging analysis of the situation within the Department. In this instance, Canada would express its disapproval of the Soviet Union's actions and ideology. This would provoke the rhetorical wrath of Soviet propaganda in the short-term.

${ }^{193}$ LAC, RG 25, Vol. 8907, File 20, Part 5. Policy Statement Distribution (PST 67) - Czechoslovak Situation, 22 August 1968; UPI-Special, "Prague invasion could affect our NATO policy: Trudeau," Toronto Star, 22 August 1968, C1, C9.

${ }^{194}$ LAC, RG 25, Vol. 8907, File 20, Part 5. Policy Statement Distribution (PST 67) - Czechoslovak Situation, 22 August 1968.

${ }^{195}$ LAC, RG 25, Vol. 8907, File 20, Part 5. Policy Statement Distribution (PST 67),-Czechoslovak Situation, 22 August 1968; Lewis Seale, "Canada may stall any plans to cut troops," The Globe and Mail, 23 August 1968, A8.

${ }^{196}$ LAC, RG 25, Vol. 8907, File 20, Part 5. Policy Statement Distribution (PST 67) - Czechoslovak Situation, 22 August 1968. 
The far-reaching goal of the policy was to ensure, however, that ultimately lines of communication remained open. The Czechoslovakian crisis helped confirm that Trudeau was not so much interested in taking down a Cold War enemy, but rather, dismantling the Cold War world order itself. This put US foreign policy in his sights as well.

Trudeau's approach to NATO in relation to the crisis put him at odds with American wishes, and Cadieux, in the days to come. If the State Department was listening to what the Canadian prime minister had to say that morning, Canada was now ruffling more superpower feathers with its response to the Czech crisis. While Canada's delegation in Washington made no mention of an American reaction to Trudeau's remarks, the US Embassy in Ottawa did release a statement from Washington the next day objecting to any intimation that the US and the Soviet Union had carved the world into "spheres of influence" at the Yalta Conference or any other time. Trudeau had mentioned Tehran and Cairo, but in doing so he had trod uncomfortably close to a French government statement attributing developments in Czechoslovakia to Yalta, ${ }^{197}$ where US President Franklin Roosevelt, British Prime Minister Winston Churchill, and Soviet Premier Josef Stalin had met early in 1945 to discuss what a post-Second World War world might look like. ${ }^{198}$

According to Canada's embassy delegation in Washington, the French statement had not been well received by officials at the State Department, particularly those who had

${ }^{197}$ See LAC, RG 25, Vol. 8907, File 20, Part 6. Message (3110), Canadian Embassy, Washington, D.C. to External Affairs, 23 August 1968; “'Spheres of Influence' Claims in Czech Crisis Totally Without Foundation.” Text. United States Information Service, US Embassy, Ottawa, 23 August 1968; LAC, RG 25, Vol. 8907, File 20, Part 9. Message regarding "Czechoslovakia - French Government's Statement and USA. Reply from Canadian Permanent Delegation, NATO Council in Brussels to Under-Secretary of State for External Affairs, 29 August 1968; Letter, Harlan Cleveland, US Permanent Representative on the North Atlantic Council, to Ross Campbell, Canadian Permanent Representative on the North Atlantic Council, 29 August 1968.

198 John Lewis Gaddis, The Long Peace: Inquiries into the History of the Cold War (New York: Oxford University Press, 1987), 48-49. 
actually been present at the Yalta Conference. The American Permanent Representative on the North Atlantic Council, Harlan Cleveland, had a similar reaction when the French statement was circulated in Brussels. The implication of such comments from the American perspective was that it had "tacitly or otherwise, [given] the Soviet Union to understand that the United States would be indifferent" to its intervention in Czechoslovakia. Any such suggestion would be "malicious and totally without foundation":

The United States Government has never entered into any 'sphere of influence' agreement or understanding with anyone anywhere in the world. There has been no discussion of any such idea in connection with recent developments in Czechoslovakia nor has any government attempted to elicit from the United States Government any such understanding. ${ }^{199}$

The crisis in Czechoslovakia saw the Trudeau government beginning to withstand hegemonic pressures within Canada's own alliance. Reducing the size of Canada's NATO forces in Europe, in particular, might be in order. This, however, would mean resisting US, as well as internal, pressure to hold the line. As a new minister in the government of L.B. Pearson, Trudeau, along with Jean Marchand and Gérard Pelletier, had joined Walter Gordon around the cabinet table on the side of those seeking a re-examination of Canada's NATO commitment. ${ }^{200}$ In the midst of the spring, 1968 Liberal Party leadership race, both Trudeau and Sharp had indicated they were in favour of reducing NATO's presence in

${ }^{199}$ Cleveland made a point of circulating the US statement to the Council members, which Campbell duly forwarded, with an attached memo, to Ottawa, along with the French statement. LAC, RG 25, Vol. 8907, File 20, Part 6. Message (3110), Canadian Embassy, Washington, D.C. to External Affairs, 23 August 1968; “'Spheres of Influence' Claims in Czech Crisis Totally Without Foundation.” Text. United States Information Service, US Embassy, Ottawa, 23 August 1968; LAC, RG 25, Vol. 8907, File 20, Part 9. Message regarding "Czechoslovakia - French Government's Statement and USA. Reply from Canadian Permanent Delegation, NATO Council in Brussels to Under-Secretary of State for External Affairs, 29 August 1968; Letter, Harlan Cleveland, US Permanent Representative on the North Atlantic Council, to Ross Campbell, Canadian Permanent Representative on the North Atlantic Council, 29 August 1968.

${ }^{200}$ Michel Fortmann and Martin Larose, "An emerging strategic counterculture? Pierre Trudeau, Canadian intellectuals and the revision of Liberal defence policy concerning NATO (1968-1969)," International Journal 59, Issue 3 (Summer, 2004): 548-549. 
Europe, arguing a need for a reassessment of Canada's NATO contribution. ${ }^{201}$ With some balking from within the affected departments, the defence and foreign policy reviews Trudeau had promised during the 1968 election campaign had already begun prior to the invasion. ${ }^{202}$

While Trudeau and Cadieux were roughly aligned on the longer-term strategy of East-West accommodation, Czechoslovakia highlighted their differences regarding the defence review and NATO. Within days of the invasion, Cadieux made his views on the matter very clear in a confidential memo to Assistant Under-Secretary R.E. Collins. "At the risk of being accused of reviving an old tune," he wrote, "I am bound to note that we were all more or less taken by surprise by the Soviet move." The Czechoslovakian occupation had demonstrated that the element of surprise could be achieved, even in the midst of a period of increased tension. Given that there might not always be adequate warning for such an action, had it not "strengthen[ed] the argument for a maximum Canadian presence in Europe"? Was it not true "that more of the same is the only way we have to discourage the hawks in the Soviet Union"? A hand-written comment on the memo notes: "NATO hasn't helped matters by virtually advertising the fact that we were caught napping." 203

As a sign of deeper differences to come, the minutes of cabinet meeting discussions during the Czech crisis capture some of the new Trudeau government's earliest debates on

${ }^{201}$ Lewis Seale, "Canada may stall any plans to cut troops," The Globe and Mail, 23 August 1968, A8.

${ }^{202}$ See Canadian Press, "Sharp Firm: Chinese objections rejected," The Globe and Mail, 13 August 1968, A25; John English, Just Watch Me: The Life of Pierre Elliot Trudeau, Vol. Two, 1968-2000 (Toronto: Vintage Canada, 2009), 57-72; Bothwell, Alliance, 284-294; James Eayrs, "From middle power to foremost power: Defining a new place for Canada in the hierarchy of world power," International Perspectives, DEA, Government of Canada, (May-June 1975), 21-22.

203 See LAC, RG 25, Vol. 8907, File 20, Part 5. "Note for Mr. Collins - The Soviet Invasion of Czechoslovakia" from the Under-Secretary of State for External Affairs (typed for M. Cadieux and signed "M.C." at end), 22 August 1968. 
the NATO question. Given that it appeared the "Soviet Bloc had become weaker," why did NATO need "to be kept strong?" went some of the back-and-forth between members. One minister made the point that "Soviet troops [were] on the western borders of Czechoslovakia in order to keep the Czechs sealed inside their country rather than to cause trouble with NATO." Cabinet agreed with Trudeau's argument that, for the time being, "nothing should be said about the reduction of NATO forces" while the government was continuing its foreign policy and defence reviews. ${ }^{204}$

On Thursday, 29 August, Sharp expressed Canada's opposition to a US proposal that NATO members issue a joint statement declaring that there would be "no immediate reduction in member commitments to the Alliance." Notwithstanding substantial pressure from the US to do so (and Cadieux's internal views), the cabinet agreed that such a statement would "prejudge the current Canadian review of foreign and defence policy, and would also tend to play into the hands of the Russians at the expense of the Alliance." The cabinet determined that Canada would maintain this position "even at the risk of isolating itself from other members of NATO."205

The Canadian government's position on NATO forces was also made clear by Sharp in a communiqué he sent to Canada's delegation at the North Atlantic Council that day. The memo was sent to guide its response to the recommendation, emanating out of the Council's Military Committee, that NATO forces in Europe be frozen in the wake of the Soviet invasion. While individual members currently contemplating force reductions might wish to indicate on their own that they now did not intend to proceed with them, Canada was not in favour of an Alliance-wide measure. Such a move would not be

\footnotetext{
${ }^{204}$ LAC, RG 2, Series A-5-a, Vol. 6338. Cabinet minutes, 28 August 1968. 6.

${ }^{205}$ LAC, RG 2, Series A-5-a, Vol. 6338. Cabinet minutes, 30 August 1968. 1-2; 7.
} 
“beneficial for NATO's image (particularly in Canada) or feasible for us in domestic political terms." It would have the effect of "injecting NATO into the Czechoslovak crisis - something which we have considered all along should be avoided." Nor did Canada wish to take any action which might prejudice the outcome, or inhibit the implementation, of its own comprehensive defence review. ${ }^{206}$

Within weeks, Trudeau would nuance, but not reverse, this position on NATO in response to Soviet posturing towards West Germany. ${ }^{207}$ At this moment, however, he remained firm. To the press that Friday, he spoke of his government's desire not to provoke the Soviets by “pass[ing] troops along the Czech border as the Russians [had] done.” Rather than handing the Soviets an "international problem" to "divert attention" from their "troubles at home," he said, "let them stew in their own brew." 208 His comment echoed an observation that Canada's NATO Ambassador R. Campbell had made to Ottawa earlier in the week. "Vigilant restraint had served NATO well in the current crisis and should continue to be the keynote." Talk of any higher level moves in the wake of the invasion "miss the main point. NATO was not in trouble but the Warsaw Pact was.",209

In the months ahead, the US would continue to press its allies to send a renewed signal of NATO resolve, and Canada would continue to resist. In a message Secretary of

${ }^{206}$ LAC, RG 25, Vol. 8907, File 20, Part 9. Message regarding "NATO: Force Reductions" from Secretary of State for External Affairs Mitchell Sharp, Ottawa to Canadian permanent delegation, NATO Council in Brussels, 29 August 1968.

${ }^{207}$ Later in September, the Soviet Union threatened to intervene in West Germany. It would be claimed that Trudeau hesitated before "grudgingly" echoing an American declaration that "it would stand by its NATO obligation to defend West Germany." At the same time it seemed to some that he was passing the buck to NATO to determine the appropriate response. See "Four plays, four stumbles in foreign policy," Toronto Star, 21 September 1968. A6.

${ }^{208}$ Canadian Press, "PM declares Canada open to refugees," The Globe and Mail, 31 August 1968, A4.

${ }^{209}$ LAC, RG 25, Vol. 8907, File 20, Part 9. Message (2086), Campbell at NATO Council in Brussels to External Affairs, 28 August 1968; North Atlantic Council (page 33), Canadian Representatives Abroad [Directory], DEA, December, 1968. Global Affairs Canada Digital Library, Jules Léger Library, Global Affairs Canada. $<$ http://www.gac.canadiana.ca $>$ 
State Rusk delivered to NATO foreign ministers, the US proposed a schedule of intensive consultations as a build-up to an earlier-than-usual, full-scale ministerial meeting in Brussels. "We may have before us a period when it will be politically possible for each of us to take steps that would provide the desired reinforcement of our NATO institution in a way which might not have been possible a few weeks ago," wrote Rusk. "The opportunity should not be lost." ${ }^{210}$ Despite Cadieux's observations from within the DEA, the Trudeau government saw another use for the Czech crisis: to signal that it would make up its own mind - on its own schedule, and for its own reasons - about its alliance contributions.

Canada's delegation in Brussels kept in close contact with Ottawa as discussions of the invasion's implications for NATO continued. It was apparent, said one of its reports, that there would be "some attempt at suggesting alterations in the balanced concept of deterrence and détente which was arrived at with such painful efforts during the Harmel exercise." Canada stood firmly against any such effort in the weeks to come. ${ }^{211}$

\section{Détente versus Liberalization}

As Canada's stance at the UN and on NATO had confirmed, the best that Czechoslovakians could expect from Canada was moral support and some wishful thinking that maybe things were not so bad. The Canadian government continued to signal that it

${ }^{210}$ LAC, RG 25, Vol. 8908, File 20, Part 12. Message (1961), External Affairs to Canadian delegation, NATO Council in Brussels, 6 September 1968.

${ }^{211}$ LAC, RG 25, Vol. 8907, File 20, Part 5. Message (2026), Canadian delegation at NATO Council in Brussels to External Affairs, Ottawa, 22 August 1968. See also LAC, RG 25, Vol. 8907, File 20, Part 4. Messages (2002-2005; 2008-2009; 2011-2013), Canadian delegation at NATO Council, Brussels to External Affairs, 21 August 1968; Messages regarding the "Czech Situation" (Numbers G.210-G.211), External Affairs to Canadian delegation, NATO Council in Brussels, 21 August 1968; Part 5. Message (2030), Canadian delegation at NATO Council, Brussels to External Affairs, 22 August 1968; Part 6. Message (2043), Canadian delegation at NATO Council in Brussels to External Affairs, 23 August 1968; Part 9. Message (2086), Campbell at NATO Council in Brussels to External Affairs, 28 August 1968. Additional messages between the delegation and Ottawa can be found in LAC, RG 25, "Czech-1-3-USSR, Czech-political affairs," Volume 8907, File 20, Parts 6-10; LAC, RG 25, "Czech-1-3-USSR, Czechpolitical affairs," Volume 8908, File 20, Parts 11-18. 
was more concerned with an acceleration of détente and the long-term peace that would bring its own citizens than it was about freedoms in Czechoslovakia. On this, Cadieux, Trudeau, and Sharp were not that far apart, but they reasoned differently. For his part, Cadieux initially saw the invasion as a Cold War triumph that the Czechoslovakians had won. Such moral victories would help bring about détente and ultimately the Cold War's end. During the Czech crisis, Trudeau and Sharp hinted at abandoning the Cold War struggle altogether. They seemed prepared to sacrifice liberalization behind the Iron Curtain to achieve this end. Both perspectives were delusional. Given the "success" they initially thought the Czechoslovakians had won on their own, Cadieux and his officials thought it best that Canada continue to avoid any undo interference. Without help from the West, Czechoslovakian "courage" would contribute in its own way towards the achievement of détente. In the meantime, however, the DEA advised Sharp to take a hard line against the USSR. The minister had other ideas.

Initial DEA assessments of the Moscow agreement were overly optimistic. It was argued, for a few days anyway, that the best of both worlds had been achieved by the outcome. Such analysis suggested that the Czechoslovakians had indeed been successful in mounting their own defence of liberalization in their country. In doing so, they were helping to pave the way towards the détente that the West still hoped for in spite of this most recent setback. As one talking point provided to the Minister by the DEA stated, “...the development of a détente and of expanding areas of understanding between nations, 
alliances and ideologies is the only hope for mankind. The courageous Czechoslovak people are making a remarkable contribution towards such a development."212

Cadieux's report to Sharp on the morning the Moscow agreement was reached called the invasion a "costly and enduring defeat" not for the Czechoslovaks, but for the Soviets, due in part to "illusions about the reception their troops would meet" in Czechoslovakia:

Instead of a pliable puppet regime and a submissive Czechoslovak populace, Moscow must now reckon with a government and party in Prague which are not only strengthened by their success but which owe that success in large part to the support of the Czechoslovak people. In this they are unlike any other Communist regime (except perhaps Yugoslavia) and it is difficult to conceive how the Dubcek regime can in the future be indifferent to the popular will. For the foreseeable future, therefore, Czechoslovakia cannot again be a reliable Soviet ally. ${ }^{213}$

A memorandum to Canada's NATO mission, also signed off by Cadieux, acknowledged that the Dubcek government no longer acted as a "free agent." If Dubcek were to retain the support of the people, however, "we consider it possible that he will be able to enlarge freedom of action and perhaps maintain effective moral and political pressure on the occupying powers." 114 Writing from Moscow, Ford observed that "I do not see how it can be interpreted except as a Soviet retreat." International Soviet prestige, even with most Communist parties around the world, had suffered, and it appeared that the Soviets had failed to secure even one single Czechoslovak collaborator willing or able to run the

${ }^{212}$ LAC, RG 25, Vol. 8907, File 20, Part 7. "Memorandum for the Minister - Czechoslovakian Situation" from the Under-Secretary of State for External Affairs (initialed "M.C." at end), 26 August 1968 [attached to this document is: "Czechoslovak Negotiations - Talking Points," 26 August 1968].

${ }^{213}$ LAC, RG 25, Vol. 8907, File 20, Part 8. "Memorandum for the Minister - Soviet Occupation of Czechoslovakia: Motives and Timing," from the Under-Secretary of State for External Affairs (stamped M. Cadieux at end), 27 August 1968.

${ }^{214}$ LAC, RG 25, Vol. 8907, File 20, Part 9. Message (No. G-40), regarding the "NAC-Czechoslovakia-NATO Government Recognition," External Affairs, to Canadian delegation, NATO Council in Brussels (cc'd to other Missions), 28 August 1968. 
country for them. The fact that negotiations in Moscow had taken four days was a sign of Czechoslovakian bargaining strength. "On the surface they tried to oust Dubcek by overwhelming military force and failed." 215

Judging from several such DEA assessments, and Canada's reaction to the Moscow agreement, it was as if a victory for freedom had been won. In one of its two statements, the Canadian government heralded the "unity, courage and restraint of the Czechoslovak people" that had "prevailed against armed might arrayed against them." The other expressed Canada's "profound admiration for the courage and steadfastness of the people of Czechoslovakia. ${ }^{216}$ In fact, liberalization in Czechoslovakia, certainly as it had been envisioned by the Prague Spring, would soon be dead. While Canada might have helped to save Dubcek himself, there was little it was willing, or able, to do to save his dream. Aside from its tributes to Czechoslovakian courage, the Canadian government did not take an overtly public stand on liberalization in Czechoslovakia. The material the DEA had provided for Sharp in expectation of an agreement being announced from Moscow had expressed "hope that Czechoslovak aspirations for a more liberal and humanitarian system can still be realized." This sentiment, however, did not make it into the final versions of Canadian statements released in response to the agreement. ${ }^{217}$

\footnotetext{
${ }^{215}$ LAC, RG 25, Vol. 8907, File 20, Part 9. Message (1791), Ford to External Affairs, 28 August 1968.

${ }^{216}$ LAC, RG 25, Vol. 8907, File 20, Part 7. "Memorandum for the Minister - Czechoslovakian Situation" from the Under-Secretary of State for External Affairs (initialed "M.C." at end), 26 August 1968 [attached to this document is: "Czechoslovak Negotiations - Talking Points," 26 August 1968]; LAC, RG 25, Vol. 8907, File 20, Part 8. "Czechoslovakia Situation," Press Release, DEA, 10:30 a.m., 27 August 1968; LAC, RG 25, Vol. 8907, File 20, Part 8. "Soviet-Czechoslovak Agreement," Press Release, DEA, 5:00 p.m., 27 August 1968; LAC, RG 25, Vol. 8907, File 20, Part 8. "Memorandum for the Minister" from the UnderSecretary of State for External Affairs (signed "M.C." at end), 27 August 1968. ${ }^{217}$ Ibid.
} 
Disturbingly early after the Moscow agreement had been reached, Sharp was already looking beyond Czechoslovakia - to a safer Canadian future. While his advisors at External Affairs had suggested taking a more punishing tone, Sharp told the Canadian Broadcasting Corporation's Ron Collister on 3 September that, while he had himself viewed the invasion "with the greatest personal horror," as Minister of External Affairs, "I'm going to proceed on the basis not of despair, but of hope." The invasion had been "a very serious setback," but "not altogether disastrous." Significantly, argued Sharp, the Soviets had, unlike the previous conditions of the Cold War, at least notified the Western countries at the time of the invasion, and had more recently "notif[ied] us again not to expect an invasion of Romania, and so on." Furthermore, given the effect it had had on Communist parties around the world and the non-aligned countries, the Soviets "surely must have learned the terrible price by invading Czechoslovakia." It was necessary to move forward "as if it is possible to discard the past, and to move into the modern world in which there is a possibility for dialogue between all peoples."218 Only fifteen days had passed since the invasion.

Striking the right balance between Cadieux's stick of disapproval and the carrot of further cooperation, Canada's interests favoured the carrot. Meeting in Ottawa on 11 September, Sharp and Ball agreed that "the Soviet invasion of Czechoslovakia [was] bound to sour the atmosphere" at the UN in the short term. It should not, however, "be allowed to

${ }^{218}$ Preparing Sharp prior to the interview, External Affairs officials had suggested Sharp could state, for example, that "the Soviet actions and that of its obedient accomplices is a brutal setback... Obviously the USSR puts its own narrow political interests above the great international principles to which it has subscribed." See LAC, RG 25, Vol. 8908, File 20, Part 11. Memorandum for the Minister concerning "Czechoslovakia," from the Under-Secretary of State for External Affairs (stamped R.E. Collins for Marcel Cadieux), 3 September 1968; "Transcript of Interview by the Honourable Mitchell Sharp for CBC News Magazine, September 3, 1968 Concerning Czechoslovakia," 3 September 1968. 
resurrect the mood of the Cold War." ${ }^{219}$ Ignatieff pursued the same course in New York. He reported that, after days of giving each other the cold shoulder, Malik was seeking to re-establish personal relations with him. ${ }^{220}$ DEA guidelines for the near future of Canada's East-West contacts put limitations on bilateral contacts in order to "reflect our continuing condemnation of the occupation of Czechoslovakia." However, Cadieux advised that "[d] espite the inevitable setback, an East-West détente - to which such contacts as these contribute - should be pursued when conditions permit." The guidelines immediately provided for certain exceptions that were in the national interest, including instances where commercial interests might be jeopardized, or the country might benefit from useful scientific and technical information. ${ }^{221}$

The government's overall tone concerning the crisis did not go unnoticed. After Trudeau spoke at the Canadian Bar Association - his first major speech since his reelection - the Globe criticized him for uttering "not a word of [his] reaction to the great events that [had] overtaken Canada and the world in recent weeks." ${ }^{222}$ His government's first Throne Speech, coming as it did on the heels of the occupation, also downplayed the severity of the crisis. " $[\mathrm{M}] \mathrm{y}$ ministers regard the current situation as uncertain and deeply disturbing," Governor-General Roland Michener said. It had caused "the gravest concern to the government not only for its effects on the prospects of détente and future evolution

${ }^{219}$ Ottawa Bureau, "Allies to avoid return to mood of Cold War," The Globe and Mail, 11 September 1968, A25.

${ }^{220}$ LAC, RG 25, Vol. 8908, File 20, Part 13. Message (2550), Ignatieff to External Affairs, 11 September 1968; LAC, RG 25, Vol. 8908, File 20, Part 13. Message (2583), Ignatieff to External Affairs, 12 September 1968.

${ }^{221}$ See LAC, RG 25, Vol. 8907, File 20, Part 9. "Memorandum for the Minister - Contacts and Exchanges with Eastern Europe" from the Under-Secretary of State for External Affairs (signed and initialed "M.C." at end), 29 August 1968; Message (G-43), regarding "East-West Contacts - Visits and Exchanges," External Affairs, to Canadian delegation, NATO Council in Brussels, 29 August 1968.

222 "Carbon Copy PM," The Globe \& Mail, 5 September 1968, A6. 
within Communist countries, but also for its consequences for the freedom and well-being of the Czechoslovak people. ${ }^{223}$ New Democrat David Lewis said he was shocked that the speech made "no condemnation of the Soviet invasion of Czechoslovakia."224

\section{Artists and Espionage}

The DEA was sympathetic to the plight of Czechoslovakians. It was more concerned, however, that any Canadian efforts to help did not make the situation worse or jeopardize Canada's longer-term interest in a thawing of relations with Communist regimes. Not all government employees and agencies saw the crisis this way. Two examples during the Czech crisis illustrate this contrast. In one case, the DEA found a way to reconcile its diplomatic goals with the good intentions of some at the National Film Board of Canada (NFB). Another instance reveals a lens through which the RCMP viewed the crisis - that Communists everywhere remained a threat.

Cole's reports from Prague suggest that Czechoslovaks were aware of Canada's initiatives at the UN and grateful for them. Czech officials who remained in office had demonstrated what Cole called "a new sense of emotional friendship and reliance on Canada." Revulsion against the Soviet betrayal, on the other hand, had "terminated any natural goodwill or sense of obligation to the USSR." 225 A passive resistance campaign was underway, but Canadian officials were being careful about how much help they were appearing to provide this effort in Prague and elsewhere. Cadieux noted to Sharp that "since the invasion we have consistently tried to act in a way that would make clear our sympathy

\footnotetext{
223 "Here is the text of the Governor-General's Throne Speech," Toronto Star, 12 September 1968, D9.

224 Ottawa Bureau, 'Long-winded alibi': 'An unswinging speech' Trudeau's great expectations land with thud, Opposition spokesmen say," The Globe and Mail, 13 September 1968, A8.

${ }^{225}$ LAC, RG 25, Vol. 8908, File 20, Part 11. Message (918), Cole to External Affairs, 3 September 1968.
} 
for the Czechoslovak authorities and people without making their position more difficult than it is already. They have repeatedly indicated their appreciation of this tactful support."226 Thus, when the Embassy in Prague informed Ottawa that the director of Czechoslovak Television had requested assistance in smuggling out film footage capturing the invasion's first few days, the message written on the telex containing the request for direction was: "Embassy as such should not get involved."227

One way or another, this footage, or footage like it, did make it onto the editing floor of the NFB. Months after the world premiere of Seven Days to Remember on the CBC programme "Newsmagazine" in the spring of 1969, the DEA noted a "TV Highlights" write-up in the Washington Post describing the documentary as a one-hour film that had been secretly shot, assembled, and edited in Canada after being carried out of Czechoslovakia in a diplomatic pouch. ${ }^{228}$

When the NFB told the DEA that it had come into the possession of such footage (inadvertently shot at the time of the invasion by filmmakers working for the Czechoslovakian government), the DEA sympathized with the desire of NFB filmmakers to get the occupation story out to North American audiences. "[W]hile recognizing their role as a government agency they feel the strong compulsions of artistic and journalistic integrity, and loyalty to the courage of their Czechoslovak counterparts," Cadieux told Sharp. "They consider there is a moral issue here of Canadians being prepared to assist in

${ }^{226}$ LAC, RG 25, Vol. 8907, File 20, Part 5. Message (789), Cole to External Affairs, 22 August 1968; LAC, RG 25, Vol. 8908, File 20, Part 16. "Memorandum for the Minister - Re: NFB Sponsorship of a Film on the occupation of Czechoslovakia" from the Under-Secretary of State for External Affairs (stamped M. Cadieux and typed initials "M.C." at end), 6 December 1968.

${ }^{227}$ LAC, RG 25, Vol. 8907, File 20, Part 6. Message (805), Embassy in Prague to External Affairs, 23 August 1968.

${ }^{228}$ LAC, RG 25, Vol. 8908, File 20, Part 18. Underlined clipping of "TV Highlights: The Bravery of the Czechs," The Washington Post, 20 August 1969, B8; Kaspars Dzeguze, "Movies: A Document of Contemporary Disaster.” The Globe and Mail, 16 May 1969, 13. 
letting the truth be known." However, as any completed film would still technically be the property of the Czechoslovakian government, the DEA was also concerned that Czechoslovak officials would not want to "upset their present delicate relationship with the Soviet Union." To avoid further jeopardizing Canada's own relationship with the Soviets, the DEA also wanted to shield the Canadian government from any appearance of involvement. $^{229}$

Cadieux and his officials devised a cover story for Sharp that would achieve this goal. Without any formal permission, but with the consent of External Affairs, the Czechoslovakian filmmaker who brought the footage to Canada was allowed to use NFB facilities to edit the film. After its completion, NFB officials wanted to present the film under the NFB banner. There was, Cadieux suggested to the Minister, possible "room for manoeuver here." It could be said that the footage was obtained by the CBC from a private Czechoslovakian refugee who refused to divulge how he had acquired or smuggled it out of Czechoslovakia. The CBC could then say that it contracted the NFB to edit it without informing External Affairs, ran it as a news feature, and then offered it to the NFB for distribution. This "would go a considerable way to blur the issues involved."230

Seven Days to Remember does not appear in the NFB catalogue, but the British Film Institute lists NFB pioneer Grant McLean as its director. The film company he

${ }^{229}$ In November, 1968, officials from the NFB informed the DEA that a team of Czechoslovakian government filmmakers who had coincidently been working on a motion picture commemorating the $50^{\text {th }}$ anniversary of Czechoslovakia's independence had instead shot footage of the Soviet occupation. One of the team, who happened to be coming to Canada on a co-production project with the NFB, reportedly took the film out of the country with the knowledge of Czechoslovak authorities. See LAC, RG 25, Vol. 8908, File 20, Part 16. Memorandum concerning "Film on Occupation of Czechoslovakia" from J.G.H. Halstead to the Acting Under-Secretary of State for External Affairs, 5 November 1968; Memorandum concerning "Film about Invasion of Czechoslovakia" from M.N. Bow to Mr. Halstead, 29 November 1968; "Memorandum for the Minister - Re: NFB Sponsorship of a Film on the occupation of Czechoslovakia" from the UnderSecretary of State for External Affairs (stamped M. Cadieux and typed initials "M.C." at end), 6 December 1968.

${ }^{230}$ Ibid. 
founded after leaving the NFB in 1967 is credited with the film's production. ${ }^{231}$ Likeminded artists still at the NFB found a way for it to be made.

Canada's spies took a different view of the Czech crisis as well. Notwithstanding Trudeau's desire to improve relations with the Communists behind the Iron Curtain, his government's intelligence apparatus was still on Cold War watch at home. Working with the DEA's Defence Liaison (2) Division, ${ }^{232}$ the RCMP made a point of monitoring both the Communist Party of Canada (CPC) and the Communist Party of Quebec (CPQ) during the Czech crisis.

The RCMP informed the DEA that CPC leader Bill Kashtan had, two days after the invasion, spent four hours in the Soviet Embassy and another three in the Czechoslovak Embassy. A member of that embassy drove Kashtan to the terminal building of the Ottawa Airport, where the two remained in conversation for ten minutes. Kashtan then entered the airport coffee shop where he was joined by A.A. Doilnitsyn of the Soviet Embassy, a senior intelligence officer for the KGB. ${ }^{233}$ The memo E.T. Galpin of Defence Liaison (2) Division prepared on these activities highlights the clear distinction that the RCMP and the Canadian

${ }^{231}$ After being passed up for the NFB's Commissioner job, McLean left the NFB and formed his own company with Board colleague Don Wilder. That company, re-named the Visual Education Centre in 1968 , is credited with the film's production. I suggest here that former colleagues at the NFB involved McLean in the project when, perhaps, new management at the NFB wanted to avoid the controversy. See Carol Cooper, "Grant McLean 1921-2002: He filmed the difficult, riled the powerful." The Globe and Mail, 11 January 2003, F8; Explore Films, the National Film Board of Canada. Visited on 29 November 2018. <http://www.nfb.ca>; "Seven Days to Remember (1968)." Explore Film \& TV. Films, TV, \& People. The British Film Institute. Visited on 29 November 2018. $<$ http://www.bfi.org.uk $>$.

232 The Defence Liaison (DL) Division was created in 1948 to deal with issues of National Defence. In 1950, it was divided into two, with the DL (2) Division looking after security and intelligence matters. See John Hilliker and Donald Barr, Canada's Department of External Affairs, Vol. 2: Coming of Age, 1946-1968 (Montreal \& Kingston: McGill-Queen's University Press, 1995), 49-50.

${ }^{233}$ LAC, RG 25, Vol. 8907, File 20, Part 5. Memorandum concerning the "Invasion of Czechoslovakia Protection of Diplomatic and Consular Services Official Premises of Warsaw Pact Countries in Canada" by E.T. Galpin, 22 August 1968; Penner, Norman. "Communist Party of Canada." The Canadian Encyclopedia. Historica Canada. Last modified 30 May 2017. Visited on 29 August 2018. $<$ http://thecanadianencyclopedia.ca/en/article/communist-party-of-canada $>$. 
Government drew at the time between the CPC and the CPQ. The CPQ released its statement (condemning the invasion) the day before the CPC issued its statement. "The CPQ," observed Galpin, "on this occasion at least, seems to be going a separate way."234

Keeping an eye on the release of the CPC's statement to a Toronto radio station was, apparently, more than just a question of media monitoring. In a separate memo, the Defence Liaison (2) Division informed the European Division that the Central Executive Committee of the CPC had met to discuss its position on the invasion. It subsequently released its statement to Toronto's CFHI the next day. The RCMP not only provided the DEA with the version of the statement released to the radio station, but also informed it of how long the Committee had met for to draft the statement. The statement itself is telling as well. While the CPC was "deeply disturbed" by the Soviet intervention, it blamed it in part on "intrigues of enemies of socialism." The invasion had enabled the "forces of imperialism to launch a political/ideological offensive against the countries of the socialist world." ${ }^{235}$ While Trudeau and Sharp may have hoped to move beyond it, the Czech crisis reveals that the Cold War was still very much on in the minds of Canada's communists and the public servants watching them.

\section{Was the DEA "Necessary?"}

The Czech crisis made another difference in approach to Canadian international relations strikingly apparent that summer: Trudeau's indifference to the DEA itself. Trudeau held a longstanding view about the DEA's usefulness. His critical view of the

${ }^{234}$ LAC, RG 25, Vol. 8907, File 20, Part 5. Memorandum concerning the "Invasion of Czechoslovakia Protection of Diplomatic and Consular Services Official Premises of Warsaw Pact Countries in Canada" by E.T. Galpin, 22 August 1968.

${ }^{235}$ LAC, RG 25, Vol. 8907, File 20, Part 6. Memorandum concerning "Communist Party of Canada Position on Invasion of Czechoslovakia" from J.J. McCardle, Defence Liaison (2), Division to the European Division, 23 August 1968. 
department and its goals went back several decades and is well-documented. ${ }^{236}$ The DEA's flurry of activity in response to the Czech crisis seems to have made little or no impression on the new prime minister's perspective. A week after the occupation began, Charles Ritchie, the veteran diplomat and Canadian High Commissioner to the UK, met Trudeau for the first time. John English describes the two encounters, but does not allude to its timing in relation to the invasion. The prime minister asked Ritchie, who had just returned from London, whether he thought the Department was "really necessary?"237 Trudeau's apparent lack of appreciation for the DEA stands out when set against the backdrop of the department's activities during the crisis. The DEA kept the cabinet briefed and provided additional interdepartmental coordination of the government's response. It helped the government keep up its diplomatic appearances not only at the UN, but also at home.

Regular memoranda from Cadieux informed the Minister and his colleagues of undertakings in New York and Brussels, and, as required, sought approval for moves to be made. ${ }^{238}$ The DEA offered political guidance to its officials abroad and considered what advice these missions might provide the government. ${ }^{239}$ The DEA also poured out thoughtful analysis on the crisis. The memoranda concerning the dismantling of the "Czechoslovak Task Force" after its two weeks of operation illuminates both its

${ }^{236}$ See English, Citizen, 209-210; 220-221; 276-277; Brendan Kelly, "The politician and the civil servant: Pierre Trudeau, Marcel Cadieux, and the DEA, 1968-1970," International Journal 2017, vol.72 (I): 5-27; Dobell, Canada's Search, 10-11; Bothwell and Granatstein, Pirouette, xiii; 378. Bothwell, Alliance, 281; Mitchell Sharp, Which Reminds Me...A Memoir (Toronto: University of Toronto Press, 1994), 167; Robert Ford, Our Man in Moscow: A Diplomat's reflections on the Soviet Union. (Toronto: University of Toronto Press, 1989), 114.

${ }^{237}$ See English, Just, 60-61.

${ }^{238}$ These began immediately. See LAC, RG 25, Vol. 8907, File 20, Part 5. "Memorandum for the Minister Czechoslovakia in the United Nations" from the Under-Secretary of State for External Affairs (signed "M.C." at end), 22 August 1968.

239 J.G.H. Halstead, head of the European Division, was in touch with an update to Prague and missions around the world on the first day of the crisis. See LAC, RG 25, Vol. 8907, File 20, Part 4. Message regarding the "Czech Situation" (Numbers S-887 and S-888), Halstead to Prague, 21 August 1968. 
effectiveness, as well as a departmental drive to improve upon internally perceived deficiencies. "Most of the urgency has gone out of the Czechoslovak crisis," wrote M.N. Bow. "[T]he need for accelerating the process of decision and for rapid collation of contributions from various divisions has now diminished. Problems prompted by the Czechoslovak situation are now of a longer-term nature and require more deliberate consideration in the divisions concerned." 240 Sharp expressed "enthusiastic appreciation" for the daily Situation Reports its members had provided on any given day of the crisis. ${ }^{241}$

In addition to these written briefs, diplomatic meetings facilitated by the DEA during the crisis were crucial. Officials were able to scrutinize the positions of both friends and those international foes with whom better friendship was desired. Prime Minister Trudeau, for one, sought improved relations with the Soviets. ${ }^{242}$ Perhaps his perspective on this, and the usefulness of the DEA, would have been slightly different had he experienced the unfolding of the Czech crisis from the beginning in Ottawa. US President Johnson met face-to-face with the Soviet Ambassador in Washington on the night of the invasion. ${ }^{243}$ The morning after, Trudeau was still in Spain.

In his stead, both Acting Prime Minister Paul Hellyer and Sharp spoke directly to Soviet Ambassador Ivan Shpedko. Hellyer joined the cabinet meeting that convened the

${ }^{240}$ See, among other reports referenced elsewhere, LAC, RG 25, Vol. 8907, File 20, Part 8. Memorandum on the "Czechoslovak Situation - Situation Report - Tuesday, August 27, 1968." 27 August 1968; LAC, RG 25, Vol. 8907, File 20, Part 9. Memorandum on the "Czechoslovak Situation - Situation Report Wednesday, 28 August 1968.” 28 August 1968; LAC, RG 25, Vol. 8907, File 20, Part 10. Memorandum concerning the "Czechoslovak Task Force" from M.N. Bow to the Under-Secretary of State for External Affairs (through R.E. Collins), 30 August 1968; LAC, RG 25, Vol. 8908, File 20, Part 11. Memorandum concerning the "Czechoslovak Task Force" from M.N. Bow to the Under-Secretary of State for External Affairs (through R.E. Collins), 4 September 1968; subsequent messages, reportage, and analysis concerning the Czechoslovak situation can be found in LAC, RG 25, Vol. 8908, File 20, Parts 11-18.

${ }^{241}$ LAC, RG 25, Vol. 8908, File 20, Part 11. Memorandum concerning the "Czechoslovak Task Force," M.N. Bow to the Under-Secretary of State for External Affairs (through R.E. Collins), 4 September 1968.

${ }^{242}$ Head and Trudeau, The Canadian Way, 220-221.

${ }^{243}$ LAC, RG 25, Vol. 8907, File 20, Part 4. Messages (3069, 3070, and 3075), Canadian Embassy, Washington, D.C. to External Affairs, 21 August 1968. 
morning after the invasion following a meeting with Shpedko at the Ambassador's request. Shpedko provided him with the same message, almost word for word, that Soviet Ambassadors had delivered in Washington and London: the Soviets had been "requested" to intervene by the Czechoslovak government "and were doing so to protect their vital interests." Hellyer expressed to Shpedko Canada's "strong disapproval."244

Sharp reiterated Hellyer's message when later that day he sent separately for Shpedko and his Warsaw Pact counterparts. According to the DEA's summary of the conversations, Shpedko appeared "ill at ease," confining himself to the barest repetition of the Soviet line and "devoid of any effort to convince." He regretted that he and Sharp appeared to have "different evaluations of events" and hoped they could find some "common language." 245 After the meeting, the Soviet Ambassador swept past reporters, saying, "We have different positions. We have explained our attitude."246

Polish Chargé d'affaires Tomkowski "was so nervous" during his meeting with Sharp that he mistook the copy of the statement that Sharp handed to him for a more formal diplomatic note. J.G.H. Halstead, head of the DEA's European Division, wrote that Tomkowski took exception to the statement's "strong attitude," particularly the assertion that Polish troops had occupied Czechoslovakia. Hungarian Chargé d'affaires Aranyi "commented in low key," admitting that the incident had taken him totally by surprise.

\footnotetext{
${ }^{244}$ See LAC, RG 25, Vol. 8907, File 20, Part 4. Britain: Telegram number 445, Foreign Office to Prague, 21 August 1968; USA.: "Text of message delivered to President by Soviet Ambassador Dobrynin, Evening, 20 August 1968; Canada: From External Affairs, to NATO, Czech Situation, Unofficial translation of text of statement by the Soviet Ambassador to Acting Prime Minister, 21 August 1968; LAC, RG 2, Series A5-a, Vol. 6338. Cabinet minutes, 21 August 1968. 1-6.

${ }^{245}$ LAC, RG 25, Vol. 8907, File 20, Part 4. Message regarding the "Czech Situation" (Numbers S-887 and S-888), J.G.H. Halstead to Prague, 21 August 1968.

246 Anthony Westell, "Sharp hands Red diplomats Cabinet statement protesting against invasion," The Globe and Mail, 22 August 1968, A9.
} 
Bulgarian Chargé d'affaires Marinov was, according to Halstead, "completely out of his depth and had nothing to say."247

In Ottawa, Sharp met First Secretary Alois Drhlik, the Czechoslovakian Embassy's Chargé d'affaires, also on that first day after the invasion. Drhlik was still acting on instructions he was receiving from his country's Ministry of Foreign Affairs, although repeated attempts at reaching it on the night of the invasion had failed. ${ }^{248}$ The meeting helped Sharp clarify that Czechoslovakia's government had not been changed, despite what the Soviet Ambassador would tell him later that afternoon. Drhlik informed Sharp that the country's Foreign Minister, Dr. Jiri Hajek, was still exercising his office (Hajek had been vacationing in Yugoslavia) and that the army had declared its full support to the properly constituted government. ${ }^{249}$ Afterwards Drhlik told reporters he was "satisfied" and “encouraged" by the meeting. ${ }^{250}$ With the DEA's help, the government would provide

${ }^{247}$ See LAC, RG 25, Vol. 8907, File 20, Part 4. Message regarding the "Czech Situation” (No. S-888) J.G.H. Halstead to Prague, 21 August 1968; DEA Telephone Directory, 1 August 1968. Jules Léger Library, Global Affairs Canada, Ottawa.

${ }^{248}$ LAC, RG 25, Vol. 8907, File 20, Part 4. Message regarding the "Czech Situation" (Numbers S-887 and S-888), J.G.H. Halstead, External Affairs, to Prague, 21 August 1968; Frank Jones, "Czech envoys listened in underwear," Toronto Star, 21 August 1968, C4.

${ }^{249}$ These meetings in Ottawa, combined with reports from around the world, confirmed how uncertain the situation was for Czechoslovakian embassies around the world. The meetings and reports also provided critical perspective for the department's development of analysis on the crisis. D.C. Reece, Counsellor at Canada's High Commission in India, reported that two days into the occupation, the Czechoslovakian Chargé d'affaires in Delhi had not received any instructions from his government. Reece wrote that the man faced an "agonizing personal decision" as his wife and child were still in Prague. See LAC, RG 25, Vol. 8907, File 20, Part 4. Message regarding the "Czech Situation" (Numbers S-887 and S-888), J.G.H. Halstead, External Affairs, to Prague, 21 August 1968; LAC, RG 25, Vol. 8907, File 20, Part 5. Message (2708), Canadian High Commission, Delhi to External Affairs, 22 August 1968; Anthony Westell, "Censure filibuster mounted," The Globe and Mail, 23 August 1968, A1.

${ }^{250}$ Sharp and Drhlik exchanged their opinions on the overall matter. Sharp commented that the Soviets had made a "very great mistake" that would be a serious blow to their prestige as well as to the progress towards an East-West détente. Drhlik replied that he thought the Soviet government would "try to use any excuse to justify intervention of its forces" and that he hoped the "maturity the Czech people had shown in recent months" would continue to prevail. It was not possible, he said, to go back to the "dirty methods," or to the period even Novotny had described as "a time of darkness." See LAC, RG 25, Vol. 8907, File 20, Part 4. Message regarding the "Czech Situation" (Numbers S-887 and S-888), J.G.H. Halstead, External Affairs, to Prague, 21 August 1968; Anthony Westell, "Sharp hands Red diplomats Cabinet statement protesting against invasion," The Globe and Mail, 22 August 1968, A9. 
Canadians of Czechoslovakian descent similar reassurance - and score some political points in the process.

\section{Czechoslovakian Canadians}

The morning after the invasion, the cabinet determined that there would be "strong pressure from the Eastern European communities in Canada" to "play a vigorous role" in the West's reaction to the crisis. ${ }^{251}$ That pressure was apparent from the beginning of the crisis. The DEA assisted the government in meeting this challenge. The DEA's Defence Liaison (2) Division, in conjunction with the European and Protocol Divisions, coordinated with the RCMP and municipal police forces to ensure adequate security, particularly focussing attention on the potential for violence arising from the presence of protestors at Warsaw Pact country embassies and consulates. ${ }^{252}$ In addition, the backgrounds of demonstration leaders were checked, and, in one instance involving a former Nazi collaborator, flagged to help the government avoid political embarrassment. ${ }^{253}$

The morning after the invasion, a delegation claiming to speak for 70,000 Canadians of Czechoslovakian origin had already arrived in Ottawa. The group was fearful that "a whole, young generation [would] be slaughtered" in the invaded country and wanted

${ }^{251}$ LAC, RG 2, Series A-5-a, Vol. 6338. Cabinet minutes, 21 August 1968. 1-6.

${ }^{252}$ LAC, RG 25, Vol. 8907, File 20, Part 5. Memorandum concerning the "Invasion of Czechoslovakia Protection of Diplomatic and Consular Services Official Premises of Warsaw Pact Countries in Canada" by E.T. Galpin, 22 August 1968; LAC, RG 25, Vol. 8907, File 20, Part 10. Note concerning "Czechoslovakia - Protection of USSR Missions," C. Roquet to Mr. Halstead and Mr. Murray. Undated.

${ }^{253}$ Before immigrating to Canada, one protest leader with whom Sharp inadvertently met had been the Secretary-General of the Tiso Government of Slovakia. The DEA informed Sharp that "the German Nazi 'protecting power' had given a substantial degree of autonomy" to this regime in the first few years of World War II. "This man's wartime activities are bitterly resented by Czechs who consider him a collaborator and a war criminal." Given that the Minister's office might be contemplating further contact with the man (Dr. Joseph M. Kirschbaum), M.N. Bow, the former Ambassador in Prague now back in Ottawa and part of the Special Task Force on the crisis, wrote that "I thought you should know who he is." See LAC, RG 25, Vol. 8907, File 20, Part 7. Memorandum concerning the "Czechoslovak Crisis Representations from Canadian Slovak Organizations" from the Czechoslovak Task Force to the Office of the Secretary of State for External Affairs (authored by M.N. Bow), 26 August 1968. 
further action from Canada. Sharp met with the delegation, anticipating the group's proposals with a re-reading of the statement he had made that morning to the press, along with his assurances about the government's openness to accepting refugees. "The delegates seemed pathetically grateful to Sharp for his strong words," wrote the Star's Frank Jones. ${ }^{254}$

The Defence Liaison (2) Division conducted background checks on Czechoslovak Canadian leaders, including Masaryk Memorial Institute Ervin Syptak, who likely would be coming into contact with Trudeau and Sharp at a demonstration planned for Parliament Hill by the Institute and the Czech National Association of Canada on the day of Trudeau's return from Spain. ${ }^{255}$ The RCMP informed the DEA that both organizations were known as "respectable anti-Communist groups" that had not been "particularly militant" in the past. Several of the individuals connected with the cavalcade were "known favourably" to the RCMP. They had previously “co-operated" with the Force. ${ }^{256}$

The next day, Trudeau and Sharp met with the group of about 125 CzechoslovakCanadian demonstrators on Parliament Hill. Their motorcade of two chartered buses and cars had left Toronto early in the morning. ${ }^{257}$ As the prime minister got out of his car to meet them on the steps beneath the Peace Tower, he was embraced by the Institute's Gustav Bristupa. Trudeau "listened soberly," wrote The Globe, as the two spoke face-to-face,

${ }^{254}$ See Ottawa Bureau, "Dispatch of UN peacekeeping force urged," The Globe and Mail, 22 August 1968, A9; Frank Jones, “"A whole generation will die,"” Czech says. Toronto Star, 21 August 1968, C1.

${ }^{255}$ Ottawa Bureau, "Invasion disappointing to Sharp, "no immediate threat to peace," The Globe and Mail, 21 August 1968, A1; "10,000 Metro Czechs await news of relatives," Toronto Star, 21 August 1968, A69; Ottawa Bureau, "Crisis brings Trudeau home," Toronto Star, 21 August 1968, A1.

${ }^{256}$ LAC, RG 25, Vol. 8907, File 20, Part 5. Memorandum concerning the "Invasion of Czechoslovakia Protection of Diplomatic and Consular Services Official Premises of Warsaw Pact Countries in Canada" by E.T. Galpin, 22 August 1968.

${ }^{257}$ See "Metro's Czechoslovak community plans convoy to take plea to PM," The Globe and Mail, 22 August 1968, A8; Ottawa Bureau, "Sharp promises Czech refugees ready welcome," The Globe and Mail, 23 August 1968. A9; Canadian Press, "Soviet Embassy occupants silent as Czechoslovaks demonstrate," The Globe and Mail, 23 August 1968, A9; UPI-Special, "Prague invasion could affect our NATO policy: Trudeau," Toronto Star, 22 August 1968, C1, C9. 
surrounded by demonstrators carrying placards and flags. Trudeau told them he wanted to "extend the sympathy of the Canadian government and to renew the assurance we gave you yesterday through the United Nations that we stood for peaceful co-operation between countries, that it was a basic principle of peace in the world that frontiers of sovereign nations be respected, and we stand for this principle." ${ }^{258}$ The government was now better attuned to the politics of the crisis. This would lead to a consequential pledge.

\section{Sharp's Promise}

A hastily-worded political promise made by Sharp under these circumstances would have significant ramifications for the government. On the day of the Parliament Hill demonstration, Sharp held a meeting with a delegation made up primarily of Toronto businessmen. According to the Globe, the vice-president of the Canadian Slovak Professional Businessmen's Association, John Stephens, "criticized what he called the total indifference of early reaction in the West." The group presented him with its proposals for further steps Canada could take. In response, Sharp echoed the government's previous commitments, but this time used specific words related to its pledge on refugees. His wording - not in keeping with Canada's working definition of "refugee" - would prove to be problematic for those officials tasked with carrying out the commitment. Sharp told the group that Canada "would give haven to any citizens of Czechoslovakia who want to get out. ${ }^{" 259}$ How the promise was kept would reveal the most significant difference in approach to Canadian international relations made evident by the crisis.

${ }^{258}$ Ottawa Bureau, "Sharp promises Czech refugees ready welcome," The Globe and Mail, 23 August 1968. A9.

${ }^{259}$ Ottawa Bureau, "Sharp promises Czech refugees ready welcome," The Globe and Mail, 23 August 1968, A9; Ottawa Bureau, "Canada will welcome Czech refugees: Sharp," Toronto Star, 22 August 1968, C1. 


\section{Chapter Two:}

The Economic Interest

In 1975, political scientist James Eayrs saw Canada at the beginning of the Trudeau era as a nation "almost sinfully bestowed upon it the sources of power, both traditional and new," "manpower" being one that was either there, or ready and waiting. "We need only decide how many millions more our country needs," Eayrs wrote, "then pick amongst the jostling clamourers according to the criteria of our choice."260 The Czech crisis prompted the first such instance of this occurring during the Trudeau era.

As with the rest of the government's response, national interest would guide its decisions on Czechoslovakian refugees. An internal debate pit Canada's diplomatic and security aims - and the well-being of Czechoslovakia - against Canada's economic goals. What began as a humanitarian pledge to people apparently in need quickly evolved into an economic undertaking to benefit Canada. Some at both the Department of Manpower and Immigration (DMI) and the DEA identified early on in the crisis a manpower opportunity for Canada. Cadieux, however, would urge the government to see the situation through the lens of diplomacy, one which took into account not only the future of East-West relations, but the very survival of Czechoslovakian society. At the heart of the matter was what would, in this instance, constitute a "real" refugee.

The morning after the invasion, Sharp put on record the government's willingness to receive refugees from Czechoslovakia, notwithstanding the absence of any such consideration in the statement approved by cabinet hours earlier. "Canada," he said,

\footnotetext{
${ }^{260}$ James Eayrs, "From middle power to foremost power: Defining a new place for Canada in the hierarchy
} of world power," International Perspectives, DEA, Government of Canada, (May-June 1975), 23-24. 
"always has the welcome mat out for people of this kind." 261 When the prime minister arrived home from Spain the next day, he similarly told reporters that Canada "has always been a hospitable country to real political refugees."262 It was on that same day that Sharp told a group of Czechoslovak-Canadians that Canada "would give haven to any citizens of Czechoslovakia who want to get out." ${ }^{263}$ Trudeau and his External Affairs minister had both made political promises they were bound to keep. They had, however, promised two very different things.

\section{An Emerging Refugee Crisis?}

The day after the invasion, the Canadian Embassy in Vienna immediately considered the possibility of a refugee crisis. Immigration officials stationed in Vienna had begun noticing an increasing number of Czechoslovakians making applications or enquiries at the embassy in early August. ${ }^{264}$ Many were already in Austria on a temporary basis for study, business, and other activities. ${ }^{265}$ There was, however, still only a slight build-up of Czechoslovakian applications from the previous two months. ${ }^{266}$

That all began to change on 21 August. Austrian radio was reporting that reception facilities were being readied, although no influx of refugees had yet been observed. ${ }^{267}$ The

${ }^{261}$ LAC, RG 25, Vol. 8907, File 20, Part 4. "Transcript of Press Conference Given by the Secretary of State for External Affairs, 21 August 1968."; "Statement by the Secretary of State for External Affairs."

${ }^{262}$ LAC, RG 25, Vol. 8907, File 20, Part 5. Policy Statement Distribution (PST 67) - Czechoslovak Situation, 22 August 1968; Lewis Seale, "Canada may stall any plans to cut troops," The Globe and Mail, 23 August 1968, A8.

${ }^{263}$ Ottawa Bureau, "Sharp promises Czech refugees ready welcome," The Globe and Mail, 23 August 1968, A9.

${ }^{264}$ Joe Bissett. "The Czechoslovakian Refugee Movement, 1968," C.I.H.S. Bulletin: The Newsletter of the Canadian Immigration Historical Society, no. 46 (July, 2005): 1-4.

265 John Zawisza, "Processing of the Czechoslovakian Refugee Movement: Vienna, Austria (Sept.-Nov. 1968)," C.I.H.S. Bulletin, no. 46 (July, 2005): 4-8.

${ }^{266}$ LAC, RG 76, Vol. 987, File IM 5782-1, Part 1. Immigration (Geneva) to DMI (Ottawa), 23 August 1968.

${ }^{267}$ LAC, RG 25, Vol. 8907, File 20, Part 4. Canadian Embassy, Vienna, to External Affairs, 21 August 1968; LAC, RG 25, Vol. 8907, File 20, Part 4. Message (759), Cole to External Affairs, 21 August 1968. 
Canadian Embassy in Vienna noted that, while very few refugees had appeared there yet, authorities said that they were ready to receive thousands if necessary. The large number of Czechoslovak tourists in Austria "wondering what to do" remained a potential source of refugees. ${ }^{268}$ DEA officials began forwarding the embassy's messages to the DMI. ${ }^{269}$

In Canada, the DMI almost immediately extended the stay of those Czechoslovakians who were already in Canada and allowed them to accept employment. This action had been taken before "in comparable circumstances." 270 Five days into the crisis, however, the question of refugees from Czechoslovakia still seemed far from acute to Canada's diplomats in bordering Austria and to immigration officials in Geneva, the headquarters of the DMI's Foreign Branch in continental Europe. The embassy in Vienna reported only a "trickle" of applicants. Even if all of the Czechoslovak tourists stranded or "sitting it out" in Austria became refugees, officials thought that this would amount to less than a thousand. While they could not estimate the numbers should the situation worsen, "we do not think there could be anything representing the Hungarian floor in 1956."271

Dudley MacWilliam, the Regional Director of Immigration in Geneva, had noted an increase in Czechoslovakian automobile traffic in the Swiss city, but at this point only a small number of enquiries at Canadian offices in centres across the so-called "Region C"

${ }^{268}$ LAC, RG 25, Vol. 8907, File 20, Part 5. Message (776), Canadian Embassy, Vienna, to External Affairs, 22 August 1968.

${ }^{269}$ LAC, RG 76, Vol. 987, File IM 5782-1, Part 1. Message (776), Canadian Embassy, Vienna, to External Affairs, 22 August 1968.

${ }^{270}$ LAC, RG 76, Vol. 987, File IM 5782-1, Part 1. Message (514-15-573), J.C. Morrison, Director General of Operations, DMI, to Regional Directors, 22 August 1968; Hand-written note to Mr. Couillard, 22 August 1968.

271 See LAC, RG 25, Vol. 8907, File 20, Part 7. Message (793), Canadian Embassy, Vienna, to External Affairs, 24 August 1968; LAC, RG 76, Vol. 987, File IM 5782-1, Part 1. Immigration (Geneva) to DMI (Ottawa), 23 August 1968; Memorandum to the Minister "Re: Czechoslovak Crisis - Refugees" from Deputy Minister of DMI Couillard, 23 August 1968; Memorandum to the Minister "Re: Czechoslovak Crisis - Possibility of Refugee Movement" from Couillard, 30 August 1968; Hawkins, Canada and Immigration, 251; John Zawisza, "Processing of the Czechoslovakian Refugee Movement: Vienna, Austria (Sept.- Nov. 1968)," C.I.H.S. Bulletin, no. 46 (July, 2005): 4-8. 
(the Foreign Branch's regional name for continental Europe). Most Czechoslovakian tourists in Europe - thousands in West Germany, Austria, and Yugoslavia with hundreds more in Belgium, Italy, and The Netherlands - were in a "state of indecision and [were] awaiting developments." The fifty thousand in Yugoslavia might in due course make their way to Austria, but Canadian officials in Geneva thought that they did not "seem to want to emigrate at the moment and don't wish to be labelled with the status of refugee." Deputy Minister Louis Couillard told the Minister of Manpower and Immigration, Allan MacEachen, that there was a possibility that Czechoslovakian refugees making their way into Germany or Austria might ultimately wish to come to Canada. For the time being, however, there was no indication that a "refugee problem" existed. A note subsequently written on the report received from Geneva indicated the next course of action agreed to in Ottawa: "wait until Monday. Picture should be perfectly clear by then."272

Despite their initial lack of urgency, Immigration officials in Geneva had seen Sharp's remarks on refugees, and sought an interpretation from Ottawa: "In view of [Sharp's] statement today 'to give a safe haven to any Czech citizen," they asked, "do you have any firm instructions to pass along as to how to deal with Czech people applying as a result?" Geneva recommended that its European offices continue with what had, as of late, been the modus operandi in dealing with enquiries and applications in Vienna: establish whether individuals could be regarded as "genuine refugee[s]", and let the existing policy govern the course of action. Geneva also suggested that the European offices ought to

${ }^{272}$ LAC, RG 25, Vol. 8907, File 20, Part 7. Message (793), Canadian Embassy, Vienna, to External Affairs, 24 August 1968; LAC, RG 76, Vol. 987, File IM 5782-1, Part 1. Immigration (Geneva) to DMI (Ottawa), 23 August 1968; Memorandum to the Minister "Re: Czechoslovak Crisis - Refugees" from Deputy Minister of Manpower and Immigration Couillard, 23 August 1968; Memorandum to the Minister "Re: Czechoslovak Crisis - Possibility of Refugee Movement" from Deputy Minister of DMI Couillard, 30 August 1968; Hawkins, Canada and Immigration, 251. 
report weekly on the incidence of enquiries and applicants. In Ottawa, Joe Bissett, the Chief of Operations for the Foreign Branch of the DMI's Immigration Service, agreed. The "present policy and procedure" appeared adequate for the current situation. ${ }^{273}$

Canada's "present policy and procedure" on refugees, however, was not consistent with Sharp's pledge to give haven to any Czechoslovakians who wanted to leave. The current policy had been developed for emergencies following World War II and, as Couillard later explained to MacEachen, had "proved invaluable in dealing with the Hungarian problem" in 1956 and 1957:274

Our present refugee policy, among other things, defines a refugee as a person who, because of fear of political persecution, left a country of Eastern Europe. Persons so defined can be dealt with under relaxed selection criteria and are not required to possess the occupational or skill requirements normally applicable to immigrants. Therefore, under our present policy our officers abroad are in a position to deal with any applications that might be received from Czechoslovak tourists if the situation develops to the point where such people are in fact refugees. ${ }^{275}$

Canada had a clear standard procedure for relaxing the selection criteria once someone was determined to be a refugee, and this was now being implemented. What was not yet clear was how Czechoslovakians who were not seen as refugees under the existing policy would be accepted as such. After all, the thousands of Czechoslovakians poised to make enquiries about immigrating to Canada had not left an Eastern European country for "fear of political

${ }^{273}$ LAC, RG 76, Vol. 987, File IM 5782-1, Part 1. Immigration (Geneva) to DMI (Ottawa), 23 August 1968; Message concerning "Recent events in Czechoslovakia" from Bissett, to Immigration (Geneva), 26 August 1968; see hand-written note on Message (1996) concerning "Canadian Policy, Acceptance of Czech refugees as immigrants," from Immigration (Geneva), to DMI (Ottawa), 1 September 1968.

${ }^{274}$ LAC, RG 76, Vol. 987, File IM 5782-1, Part 1. Memorandum to the Minister "Re: Czechoslovak Refugees" from Deputy Minister of DMI Couillard, 3 September 1968.

${ }^{275}$ LAC, RG 76, Vol. 987, File IM 5782-1, Part 1. Memorandum to the Minister "Re: Czechoslovak Crisis Possibility of Refugee Movement” from Deputy Minister of DMI Couillard, 30 August 1968. 
persecution." Most had left as relatively affluent tourists with "tennis rackets tucked under their arms" before their country had been invaded. ${ }^{276}$

The procedure in this instance would take shape under the auspices of an Immigration Department whose name had just had "manpower" added to it, and some, but not all, in the DEA who saw an economic opportunity for Canada. ${ }^{277}$ As officials pointed out, Sharp's commitment had not been made in consultation with the DMI, let alone the cabinet. ${ }^{278}$ Yet Bissett told his staff in Geneva that while "no special facilitating procedures seem[ed] necessary at present," Sharp's statement "would undoubtedly be honoured if tested." 279

Further clarification would be required. The sooner it came, it was argued, the better - not for Czechoslovakians, but for Canada. One week into the crisis, the Canadian Embassy in Vienna began observing the refugee situation "assuming new dimensions" for Austrian authorities dealing with the tens of thousands of Czechoslovakian tourists who had been stranded elsewhere, particularly in Yugoslavia and Italy, and who were starting to arrive in Austria. ${ }^{280}$ Czechoslovakians in Europe and elsewhere were weighing their options. Canada was one of them, and it stood to benefit. The Canadian Consulate-General

${ }^{276}$ Mike Molloy, "Vienna 1968: discovering the world." C.I.H.S. no. 46 (July, 2005). 13-15.

${ }^{277}$ In his own account, Bissett describes how, a year before, the L.B. Pearson government had re-organized the Department. In addition, it had liberalized the regulations related to immigration (making them nondiscriminatory), introduced a new points-system based on nine factors of selection, and established an Immigration Appeal Board. Bissett writes of officials in the Foreign Branch of the DMI's Immigration Service having to adjust to new chains of command as they carried out their work within a branch "buried" inside the larger department responsible for the supply of labour to Canada's workforce. See Joe Bissett, "The Czechoslovakian Refugee Movement, 1968," C.I.H.S. Bulletin, no. 46 (July, 2005): 1-3.

${ }^{278}$ LAC, RG 76, Vol.1402, File IM 5782-1, Part 4. "Notes for Mr. Curry Re: Czechoslovak Refugee Paper," 3 October 1968.

${ }^{279}$ LAC, RG 76, Vol. 987, File IM 5782-1, Part 1. Immigration (Geneva) to DMI (Ottawa), 23 August 1968; Message concerning "Recent events in Czechoslovakia," Bissett to Immigration (Geneva), 26 August 1968.

${ }^{280}$ LAC, RG 25, Vol. 8907, File 20, Part 8. Message (807), Canadian Embassy, Vienna, to External Affairs, 27 August 1968. 
in Marseilles, for example, fielded a request from a doctor of chemistry with ten years of experience in the pharmaceutical industry. He wrote that the chemist and his wife "strike me as potentially valuable immigrants.” They spoke multiple languages, including English and French, had previously worked in Canada, and had friends and contacts in the country they could count on for financial and professional support. ${ }^{281}$

About 120 Czechoslovakians tourists interested in immigrating to Canada had approached the embassy in Belgrade. Canada's Ambassador to Yugoslavia, B.M. Williams, expressed concern to both the DEA and DMI in Ottawa that the instructions that had been provided to the Embassy's Immigration officer seemed "unrealistic." Ascertaining whether or not Czechoslovakians calling at the Embassy were serious about emigrating, taking their names, and telling them that they would be contacted later, was not an effective "method of dealing with the present situation." 282 Furthermore, without an adequate response, Williams observed that Canada might lose an opportunity to accept very high "calibre" immigrants. The thousands of Czechoslovakian tourists stranded in Yugoslavia were "highly qualified citizens" of their country because they were the ones able to amass the resources necessary for a holiday abroad. "[W]e are faced with a pool of excellent potential immigrants," he wrote. "If countries like Canada do not accept them they will be forced to return to Czechoslovakia." 283

${ }^{281}$ LAC, RG 76, Vol. 987, File IM 5782-1, Part 1. Message (169), Canadian Consulate-General, Marseilles, to External Affairs, 24 August 1968.

${ }^{282}$ LAC, RG 25, Vol. 8907, File 20, Part 10. Message (820), concerning "Canadian Policy - Acceptance of Czech Refugees as Immigrants," the Canadian Embassy, Belgrade to DEA and DMI, (Ottawa), 30 August 1968. Yugoslavia (page 49), Canadian Representatives Abroad [Directory], DEA, December, 1968. Global Affairs Canada Digital Library, Jules Léger Library, Global Affairs Canada. $<$ http://www.gac.canadiana.ca $>$

${ }^{283}$ Ibid. 
Williams was also concerned about their well-being. The longer they had to await a firm response from Canadian officials, the more difficult it would be for them, many with expired travel documents, to explain their extended absence to Czechoslovakian authorities. Given the statement made by Sharp, Williams stressed the need for the embassy to be able to give those who were inquiring a definite response. "[W]e sincerely hope the answer will be in the affirmative." He also pointed out that, if Canada were to extend a welcome to those who had already applied, a greater number could be expected to do the same. As for what refugee criteria ought to be applied to those doing so, he advised that "we should not be merely concerned whether they are or are not refugees in the technical sense of everyday refugees. For us to take any will cause some disruption but this is the price of offering 'safe haven.", 284

Williams' observations were echoed by his counterparts in Prague and Vienna. They suggested a relaxation in procedures that, while not altering the definition of refugee, would at least make it easier for certain pre-approved Czechoslovaks endeavouring to leave their country legally to bypass the normal process. The embassy in Prague recommended steps that would streamline the handling of applications for Czechoslovaks with valid passports and exit visas who were already in possession of, or had previously been issued, a Canadian visa, and who had friends or relatives in Canada. A DMI official in Ottawa observed: "These sound like very sensible suggestions that would enable SSEA [Sharp] to say that action has been taken to expedite acceptance of refugees." 285

${ }^{284}$ LAC, RG 25, Vol. 8907, File 20, Part 10. Message (820) concerning "Canadian Policy - Acceptance of Czech Refugees as Immigrants" from the Canadian Embassy, Belgrade to External Affairs and DMI (Ottawa), 30 August 1968.

${ }^{285}$ LAC, RG 76, Vol. 987, File IM 5782-1, Part 1. Message (894), concerning "Proposed relaxation of Visa procedures for Czechoslovakia" from the Canadian Embassy, Prague to External Affairs, (Ottawa), 30 August 1968. 
In the end, Canada would go even further to keep Sharp's pledge. On Friday, 30 August, Trudeau held a news conference before heading west for a holiday weekend stopover in the mountains of Jasper, Alberta. ${ }^{286}$ He repeated the government's pledge to admit Czechoslovakian refugees requesting entry into Canada. ${ }^{287}$ It had been ten days since Sharp had made the original commitment, but any details connected to this promise had yet to be vetted by cabinet or announced to the public. Now, pressure was mounting not only to provide immigration offices on the ground the guidance and resources that they needed to process a growing number of applications, but also to give Trudeau, Sharp, and MacEachen something to announce.

At the same time, the media both in Canada and in Europe was beginning to hone in on the story. ${ }^{288}$ As will be discussed, one Globe editorial in particular would strike a chord with Cadieux. He would use it to highlight what ultimately he saw as the error in Canada's approach to Czechoslovakia. Amid reports from Prague that intellectuals and “counter-revolutionaries" were coming under the assault of threatening Soviet propaganda, both the Globe and the Star scorned Trudeau for his "less than enthusiastic espousal" of the refugee cause at his Friday press conference. Given the fact that "most Canadians [felt] deeply and personally concerned with the assault on the blossoming freedom of Czechoslovakia," the Globe was struck by the prime minister's “casual cynicism," his "academic" tenor, and the lack of urgency akin to Sharp's "placid" words the night of the invasion. The prime minister, it said, "should fiddle no longer." It added: "We should hate

${ }^{286}$ Canadian Press, "PM holidays at Jasper," The Globe and Mail, 31 August 1968, A4; Canadian Press. "PM climbs mountain near Jasper," The Globe and Mail, 1 September 1968, A8; "Carbon Copy PM," The Globe and Mail, 5 September 1968, A6.

${ }^{287}$ Canadian Press, "PM declares Canada open to refugees," The Globe and Mail, 31 August 1968, A4.

${ }^{288}$ See LAC, RG 25, Vol. 8907, File 20, Part 7. Message (789), Canadian Embassy, Vienna, to External Affairs, 24 August 1968. 
[our immigration officers in Europe] to be infected with the Trudeau-Sharp lethargy in a field where the realities are despair and desperation." The Star noted Trudeau's "cold" tone, unreflective of "Canadian sentiment in this matter."289

Thousands of intellectuals on a Russian black list were an entirely different kind of refugee than what Canada's officials were actually encountering in Prague, Vienna, and Belgrade. Yet the Globe's editorial on Saturday had suggested a similar "beef[ing] up" of staffs also being advocated by those same officials on the ground. "It is disgraceful," wrote the paper, "if such a program has not already been instituted." ${ }^{290}$ Such a programme had not yet been initiated, but the DEA did send the embassy in Prague approval on Saturday to proceed with the streamlined application process it had suggested the day before. ${ }^{291}$

While DEA and DMI officials were still grappling with what constituted an actual refugee in this situation, they also had reason to believe that legitimate refugees could be helped. Government leaders or "leading personalities" in Czechoslovakia feeling threatened for their political views would, of course, fit the actual definition of refugee. External Affairs tried to clarify just how much danger "persons in key positions of influence" might be in. M.N. Bow asked the embassy in Prague if it could confirm whether or not Czechoslovakian Prime Minister Cernik had warned Czechoslovakian intellectuals to "get out while they can," as had been reported in a Reuters news story. ${ }^{292}$ The embassy wrote back that their American counterparts had been told "by certain intellectuals" that

289 "A certain urgency, please," The Globe and Mail, 31 August 1968, A6; “A black night for Czechoslovakia," Toronto Star, 31 August 1968, A6.

290 "A certain urgency, please," The Globe and Mail, 31 August 1968, A6.

${ }^{291}$ LAC, RG 25, Vol. 8907, File 20, Part 10. "Memorandum for the Minister - Czechoslovakian Refugees" from the Under-Secretary of State for External Affairs (initialed "M.C." at end), 31 August 1968; LAC, RG 76, Vol. 987, File IM 5782-1, Part 1. Message (C-47), concerning "Proposed Relaxation of Visa Procedure for Czechoslovakia," External Affairs (Ottawa) to Embassy in Prague, 31 August 1968.

${ }^{292}$ LAC, RG 25, Vol. 8907, File 20, Part 10. Message (Number G-44), regarding the "Czechoslovak Situation," M.N. Bow to Prague, 30 August 1968. 
Cernik had said that "we have no way of knowing what the Russians will do and we can guarantee nothing." While there had been no confirmed arrests since 21 August, the Embassy concluded that the "general feeling here is that a crackdown may be coming."293

\section{Cadieux Weighs In}

As Trudeau set out on his holiday in Jasper, the DEA and the DMI got to work that Labour Day weekend on a more concrete plan. Cadieux had advised Sharp that while the number of applicants to Canada was still small, it seemed likely that large numbers of Czechoslovakians - both intellectuals fearing repression and many of the more than 100,000 tourists stranded in countries like Yugoslavia, Austria, and elsewhere - would be seeking refuge in Western countries. Sharp's own public statement, he wrote, was what had prompted them to start getting ready. ${ }^{294}$

The Czech crisis would thus reveal another difference in approach to Canadian international relations that summer. Declaring that "any Czechoslovakians who wanted to leave" could come to Canada as refugees had implications for both Czechoslovakia and Canada. Perhaps Sharp had not thought of this when he made his political pledge. Now, Cadieux was telling him, and urging caution. There was a danger that Canada's efforts on this front could be perceived in a way that would make matters worse for the people and country it had been seeking to help. "There is no doubt," he wrote to Sharp, "that apart from its humanitarian aspects this problem has implications touching the eventual survival of the Czech and Slovak nations." He observed that Czechoslovakia had seen after both

${ }^{293}$ LAC, RG 25, Vol. 8907, File 20, Part 10. Message (923) concerning "Czechoslovak Situation" from the Canadian Embassy, Prague to External Affairs, (Ottawa), 31 August 1968.

${ }^{294}$ LAC, RG 25, Vol. 8907, File 20, Part 10. "Memorandum for the Minister - Czechoslovakian Refugees" from the Under-Secretary of State for External Affairs (initialed "M.C." at end), 31 August 1968. 
the Second World War and 1948 "the best of their intelligentsia" destroyed, and if this were to happen again, "it would be reasonable to wonder whether Czechoslovak society could recover in the foreseeable future." 295

Indeed, he pointed to the same Globe editorial so critical of Trudeau and Sharp that day as an example of how the government should not proceed. There was, he agreed, an obligation on the part of the West to do all it could to help, but precisely the opposite purpose would be served at this stage "by publicized measures" of the kind advocated by the paper. Canada should not seem to be taking actions which might provoke persecution:

We can facilitate the entry of Czechoslovak refugees to Canada; we cannot help them escape from Czechoslovakia. To pretend we can would only encourage false hopes and in fact make such escape more difficult...no better way of endangering the survival of the Czechoslovak intelligentsia could be found than for Western governments to create the image of a concerted campaign to incite them to leave..."296

It was a message that once again put Marcel Cadieux at odds with the Trudeau government and its approach to international relations during the Czech crisis.

Instructions to Europe and a DEA press release issued out of Ottawa that weekend initially reflected Cadieux's call for a more toned-down approach to the refugee issue. Bissett directed that a top official from the Foreign Branch's Geneva headquarters proceed at once to Belgrade to assess the situation there. ${ }^{297}$ The DEA asked the embassy in Belgrade to provide a similar assessment in consultation with the DMI official now on his way there. The instructions noted that "we would not of course wish at this time to stimulate

${ }^{295}$ LAC, RG 25, Vol. 8907, File 20, Part 10. "Memorandum for the Minister - Czechoslovakian Refugees" from the Under-Secretary of State for External Affairs (initialed "M.C." at end), 31 August 1968.

${ }^{296}$ Cadieux told Sharp that it might be useful if he had the opportunity to make this point back to the Globe and Mail. See Ibid.

${ }^{297}$ LAC, RG 76, Vol. 987, File IM 5782-1, Part 1. Message (C-48), concerning "Canada Policy - Acceptance of Czech Refugees as Immigrants - For MacWilliam from Bissett," DMI (Ottawa) to Immigration (Geneva), 31 August 1968. 
widespread refugee interest in Canada." ${ }^{298}$ In addition to noting the dispatch of the official to Belgrade, the DEA press release announced that the Canadian Embassy in Prague had "been authorized on an urgent basis to streamline the handling of applications from Czechoslovaks who are able to leave Czechoslovakia" and that similar measures were being taken elsewhere to expedite the process. While most applications so far were coming from Czechoslovaks with family and friends in Canada, measures were being readied to deal with any increase. "At the same time," the statement said, "we must realize that many who might want to leave may not be able to." It concluded: "Concern for the welfare of those who can leave should not blind us to concern for those who must remain."299

Those officials in Europe at the receiving end of Ottawa's instructions, however, included the likes of Ambassador Williams, who had only the day before noted the potential pool of high "calibre" immigrants at Canada's doorstep. ${ }^{300}$ Regional Director of Immigration MacWilliam, the top official being sent to Belgrade, reported to Ottawa that, while there remained "no cause for concern" that a potential refugee movement of Czechoslovakians in Yugoslavia and elsewhere could not be dealt with adequately on the basis of the criteria previously authorized, current policy "complicated" the response Canadian officials could give to those making independent applications. ${ }^{301}$

${ }^{298}$ LAC, RG 25, Vol. 8907, File 20, Part 10. Message (C-49), concerning "Czechoslovak Refugees," External Affairs (Ottawa) to the Canadian Embassy in Belgrade, 31 August 1968.

${ }^{299}$ LAC, RG 25, Vol. 8907, File 20, Part 10. “Czechoslovakian Refugees," Press Release, DEA, 31 August 1968.

${ }^{300}$ LAC, RG 25, Vol. 8907, File 20, Part 10. Message (820), concerning "Canadian Policy - Acceptance of Czech Refugees as Immigrants," the Canadian Embassy, Belgrade to DEA and DMI, (Ottawa), 30 August 1968.

${ }^{301}$ LAC, RG 76, Vol. 987, File IM 5782-1, Part 1. Message (1998), Immigration (Geneva) to DMI (Ottawa), 1 September 1968; Message (1996) concerning "Canadian Policy, Acceptance of Czech refugees as immigrants," Immigration (Geneva) to DMI (Ottawa), 1 September 1968. 
The policy still defined a refugee as a person who left a country of Eastern Europe for fear of political persecution. MacWilliam noted that, in 1956, Hungarians fleeing their Eastern European country made a "definite choice" between West and East. Czechoslovakia was different. In this case, only a small number of those outside of Czechoslovakia as tourists fit the refugee definition. Most enquiring in Vienna and Belgrade, he observed, were expressing no concern about the possibility of economic or physical jeopardy should they return to Czechoslovakia. Instead, they were either worried about losing the opportunity to apply upon returning to their country, or saw emigration as a possible alternative to returning to Czechoslovakia if employment and settlement prospects elsewhere offered "more promise" than a resumption of their former life. Canada could, however, adjust its working definition of refugee to better fit the circumstances. MacWilliam suggested "a more liberal refugee definition such as a "person who has left or elected to leave [after] a country [of which he is a national] suffering occupation or suppression of its institutions by a foreign power.",302

Apparently, other Western countries were already facilitating the exit of Czechoslovakians by a more "liberal issuance" of visas. "[I] would think," argued MacWilliam, "that a large movement based on [this] suggested revision of the refugee definition would not result in a movement impossible to contain." He also argued that Canada's humanitarian reaction should not be limited geographically to Prague alone, since it was his understanding that exit permits were continuing to be granted and departure from Czechoslovakia was still possible. If Canada was already streamlining the process for

302 Ibid. 
Czechoslovakians inside the country, it should do the same for those who happened to be outside of it. This would be made possible by the revision of the refugee definition. ${ }^{303}$

Ambassador J.A. McCordick in Vienna made a similar case for the streamlining of applications received outside of Czechoslovakia. On 1 September, Geneva highlighted to Ottawa that, on the basis of the present refugee policy, forty percent of those Czechoslovaks in Vienna indicating an interest in immigrating to Canada had been refused. ${ }^{304}$ According to figures McCordick had received, 13,500 Czechoslovakians had crossed into Austria from their country after the beginning of the invasion. Having made a deliberate decision to do so, these people were more likely to be a source of refugees than the tourists caught abroad at the time of the invasion. Canada, he wrote, was "one of the top choices." Noting that the embassy in Prague had been authorized to streamline the handling of applications from Czechoslovakia, McCordick asked Ottawa if similar streamlining would also be authorized for those applying from Austria. "I should hope this would be possible. ${ }^{\prime 305}$

In line with these suggestions, but with no initial cabinet approval, DMI and DEA officials ultimately found it simpler, and more advantageous for Canada, to adopt Sharp's criteria as the basis for accepting applicants from Czechoslovakia. In effect, the minister's commitment that Canada "would give haven to any citizens of Czechoslovakia who want to get out" became the working definition of refugee that the government would apply to the current crisis. A memorandum issued by DMI Director General of Operations J.C.

\footnotetext{
${ }^{303}$ Ibid.

${ }^{304}$ LAC, RG 76, Vol. 987, File IM 5782-1, Part 1. Message (1999), Immigration (Geneva) to DMI (Ottawa), 1 September 1968.

${ }^{305}$ LAC, RG 76, Vol. 987, File IM 5782-1, Part 1. Message (838), Canadian Embassy, Vienna, to External Affairs, 3 September 1968.
} 
Morrison referenced the acceptance of those Czechoslovakians "wishing to emigrate to Canada due to the political situation in their country." "For the purposes of immigrating to Canada," Morrison stated, "such persons have been declared refugees, and the special refugee procedures will be invoked." ${ }^{306}$

This adjustment would serve Canada's political, humanitarian, and economic interests, but further the divide between Cadieux and those who appeared to relish the manpower opportunity that the crisis presented. As for cabinet approval of the policy, Deputy Minister Couillard addressed this with his minister when he noted that "[i]t was certainly not felt necessary to get Cabinet approval for the course of action" officials were now taking as those measures were ones already "used continuously in individual cases that arise. ${ }^{307}$ But there was a difference. Any Czechoslovakian wanting to emigrate, not just those facing political persecution, would be treated as a refugee.

The steps being taken were politically important for a government trying to counter a perception that Canada was still not doing enough. CBC journalist Michael Maclear confronted Sharp with the suggestion that there seemed to be "some confusion as to whether [Czechoslovakian refugees] were welcome in Canada or not." Their "man in Vienna" had not seen Canadian Embassy representatives around the refugee camps and on Labour Day, according to him, no one at the embassy was answering calls. Sharp responded that there had been significant progress. "We are moving people into Vienna.",308

${ }^{306}$ LAC, RG 76, Vol. 987, File IM 5782-1, Part 1. Memorandum concerning "Czechoslovak Refugees" from J.C. Morrison, Director General of Operations, DMI, to Regional Directors, 5 September 1968.

${ }^{307}$ LAC, RG 76, Vol. 987, File IM 5782-1, Part 1. Memorandum to the Minister "Re: Czechoslovak Refugees," from Deputy Minister of DMI Couillard, 3 September 1968.

${ }^{308}$ LAC, RG 25, Vol. 8908, File 20, Part 11. "Transcript of Interview by the Honourable Mitchell Sharp for CBC News Magazine, 3 September 1968 Concerning Czechoslovakia," 3 September 1968. 
John Zawisza, the Officer-in-Charge in Vienna, recalls interpreting his instructions from Geneva to above all "proceed judiciously" without giving anyone, "especially journalists, External Affairs, the Czechoslovakian lobby in Canada or any one [sic] else grounds for criticizing the Department [of Manpower and Immigration]." ${ }^{309}$ Officials in Ottawa, Vienna, and Belgrade would remain wary of the press as reporters continued to pursue the storyline that Canada's refugee effort had been deficient in its early stages. ${ }^{310}$

Part of that perception had been caused by the apparent lack of specific direction Canadian officials in Europe had received from Ottawa. ${ }^{311}$ Further instructions Bissett sent out to Geneva (unencrypted, to the dismay of External Affairs) re-iterated that officials on the ground could apply the relaxed guidelines prescribed by the existing refugee policy to any "Czechoslovaks outside of Czechoslovakia you consider to be genuine refugees and who have expressed sincere desire to come to Canada." 312 But Bissett's instructions did not clarify what, in this case, now constituted a "genuine refugee." MacWilliam wrote back to Bissett that "I have interpreted your selection policy that Czech refugees are acceptable...if they are strongly motivated against a return to Czechoslovakia and have expressed a sincere desire to go to Canada." 313 This policy applied to Czechoslovakian nationals residing temporarily in any country, including visitors to Canada. ${ }^{314}$

309 John Zawisza, "Processing of the Czechoslovakian Refugee Movement: Vienna, Austria (Sept.-Nov. 1968)," C.I.H.S. Bulletin, no. 46 (July, 2005): 4-8.

${ }^{310}$ LAC, RG 76, Vol. 987, File IM 5782-1, Part 2. Message (844), the Canadian Embassy, Belgrade to External Affairs and DMI (Ottawa), 6 September 1968.

${ }^{311}$ Ibid.

${ }^{312}$ LAC, RG 76, Vol. 987, File IM 5782-1, Part 1. Bissett to Immigration (Geneva), 4 September 1968; LAC, RG 25, Vol. 8908, File 20, Part 12. "Memorandum for European Division and Consular Division" from John Starnes, 6 September 1968.

${ }^{313}$ LAC, RG 76, Vol. 987, File IM 5782-1, Part 1. Message (1651), regarding “Czech refugees," Immigration (Geneva) to DMI (Ottawa), 6 September 1968.

${ }^{314}$ LAC, RG 76, Vol. 987, File IM 5782-1, Part 6. Memorandum to the Minister, DMI, 11 October 1968. 
A policy adjustment initially based on Sharp's humanitarian promise was facilitating a process that put Canada's economic interests, rather than Czechoslovakia's, front and centre. MacWilliam was keen to get on with the processing of Czechoslovakians in Yugoslavia who were receiving less support from the government there. "[T]hese unfortunate people" were, he wrote to Ottawa, "highly qualified and very good candidates," but if Canada did not act quickly, they would be forced to return to head northward. "Now is the time we should appear to be doing all we can to facilitate the move to Canada for those who wish to go."315

One communication out of Geneva referenced a prevailing opinion in the Vienna office that the "selection criteria should be such that higher quality rather than quantity is the important factor." 316 "I am most impressed with the calibre of Czechs I am personally meeting," wrote MacWilliam to Ottawa, "and very proud to welcome them as new Canadians." 317 The Visa Office attaché in Stockholm similarly observed that most applicants "qualified without any relaxation of criteria."318

The recollections of those involved in the programme confirm this approach. The visa officers made "good use" of their discretionary power in "the choice of refugees for Canada."319 Daryl Mesheau, one of those officers, recalls that "I had no problem with fudging the definition because the quality of the people who were asking to immigrate was

${ }^{315}$ LAC, RG 76, Vol. 987, File IM 5782-1, Part 1. Message (1634), Immigration (Geneva) to DMI (Ottawa), to the attention of IMADM, 4 September 1968.

316 LAC, RG 76, Vol.1402, File IM 5782-1, Part 4. Message regarding "Czech Refugee Movement," Immigration (Geneva) to DMI (Ottawa), 9 October 1968.

${ }^{317}$ LAC, RG 76, Vol. 987, File IM 5782-1, Part 1. Message (1651), regarding “Czech refugees,” Immigration (Geneva), to DMI (Ottawa), 6 September 1968.

${ }^{318}$ LAC, RG 76, Vol.1402, File IM 5782-1, Part 3. Memorandum to Director, C.G.I.S., Europe, Geneva "Re: Czech. Refugees" from Attaché, Visa Office, Stockholm, Sweden, 3 September 1968.

319 Joe Bissett, "The Czechoslovakian Refugee Movement, 1968," C.I.H.S. Bulletin, no. 46 (July, 2005): 3; LAC, RG 2-A-1-a, Vol.2380, PC 1967-1616, "Immigration Act, Immigration Regulations, Part 1, Amended, Schedule A: Norms of Assessment of Independent Applicants,” 16 August 1967. 
so high." ${ }^{320}$ In charge of the operation in Vienna, John Zawisza remembered that the "overall quality of the Czech movement was excellent." Applicants were "mainly experienced, well-trained skilled workers and technicians."321 Mike Molloy, another immigration officer, confirmed that "they represented a gold mine of skills and talent."322

\section{Talent Team and "a Good investment"}

Two weeks after Sharp's initial pledge, Canada's programme for Czechoslovak refugees was finally up and running. Internal debate over the programme's ultimate motivation was set to spread to the cabinet level, as well to other government departments and agencies. Only now was cabinet being apprised. Financial approvals were required. The economic benefits to Canada were made immediately clear, but meeting Sharp's political pledge would cost the government money. As in 1956, the Czechoslovak refugee movement was going to require a larger budget. The main costs involved transportation. Additional funding would also provide for medical tests, language training, and maintenance costs prior to individuals becoming self-sustaining in Canada with employment. Cabinet would need to decide whether those costs would be met on the basis of Assisted Passage Loans or on a non-recoverable basis. To Minister MacEachen, Couillard recommended the latter. "I have a considerable reservation on any plan that would require these refugees to pay for their passage, even with a loan from us." ${ }^{323}$

\footnotetext{
${ }^{320}$ Daryl Mesheau, Untitled. C.I.H.S. Bulletin, no. 46 (July, 2005): 13.

321 John Zawisza, "Processing of the Czechoslovakian Refugee Movement: Vienna, Austria (Sept.-Nov. 1968)," C.I.H.S. Bulletin, no. 46 (July, 2005): 7.

322 Mike Molloy, "Vienna 1968: discovering the world." C.I.H.S. Bulletin, no. 46 (July, 2005). 13-15.

${ }^{323}$ LAC, RG 25, Vol. 8908, File 20, Part 12. "Memorandum for the Minister - Czechoslovak Refugees" from the Under-Secretary of State for External Affairs (initialed "M.C." at end), 3 September 1968; LAC, RG 76, Vol. 987, File IM 5782-1, Part 1. Memorandum to the Minister "Re: Czechoslovak Refugees" from Deputy Minister of Manpower and Immigration L. Couillard, 3 September 1968; LAC, RG 76, Vol. 987, File IM 5782-1, Part 1. Memorandum for the Minister "Re: Czechoslovakian Refugees" from Deputy Minister of the DMI Couillard, 4 September 1968.
} 
The cabinet's discussion over the refugee programme's costs - and motivation extended over two meetings, the first taking place on 5 September. Because there was still refugee movement out of the country, it was not yet possible to know what the final monetary figure might be. MacEachen informed his colleagues that around 500 applications had already been received, and it was estimated at the time that the total number would reach 2,000 The costs per head for transportation and settlement would be approximately $\$ 1,000$, twice as much, he pointed out, as the amount spent per Hungarian refugee in 1956. In the ensuing discussion, it was observed that it probably would not be a good idea to ask Czechoslovakians and Hungarians living in Canada to become directly involved in the programme's official arrangements. Either the government should pay for all transportation and settlement or none at all. Several ministers having expressed concerns, the final decision on costs was left for the next meeting. ${ }^{324}$

Speed was of the essence. That week, the DMI issued a media release referring to Canada's initiative on the refugee front as an "important humanitarian effort." 325 While the announcement made no initial reference to the skill levels of the Czechoslovakians applying to the programme, Canadian officials continued to pay particular attention to the benefits that talented refugees might offer Canada's workforce. In the second of two memoranda that Couillard sent to MacEachen prior to that week's cabinet meeting, he noted that hundreds of applicants in Yugoslavia were in their twenties and early thirties and with "exceptional academic qualifications." Venturing explicitly into the territory his

${ }^{324}$ LAC, Privy Council Office fonds, RG 2, Cabinet minutes Series A-5-a, Vol.6338, 5 September 1968. 12; 8-9; 10 September 1968. 4-5.

${ }^{325}$ LAC, RG 76, Vol. 987, File IM 5782-1, Part 1. Press Release, Department of Manpower and Immigration, 6 September 1968; Message regarding Press Release issued, DMI (Ottawa) to Immigration (Geneva), 6 September 1968. 
counterpart at External Affairs had been warning against, Couillard wrote: "Another aspect of this whole program that merits emphasis, I believe, is that with respect to outstanding scientific and professional people among the refugees...I think that the possibility of identifying a number of people who have special capabilities in various aspects of scientific research, for example, is well worth pursuing." He suggested that a small team representing Canada's research and academic institutions could be sent to Vienna "to help identify such people and attract them to Canada." There certainly would be a "keen effort" on the part of the US, Australia, and others to do the same. "Canada ought to give this matter prompt and meaningful attention." ${ }^{326}$ As Couillard had recommended, MacEachen asked his cabinet colleagues to consider the desirability of sending such a team to Europe. ${ }^{327}$

Cadieux was more than ever concerned not only about the effect that Canada's efforts would have on Czechoslovak society, but also that the Soviets might latch on to the refugee programme and raise objections. As part of its 5 September discussion, cabinet was reminded that the Minister of Immigration had gone to Vienna during the Hungarian crisis. A team headed by a Senator, it was suggested in cabinet, might do the same this time. Cadieux told Sharp that he thought this would be "a mistake because it would have the appearance of a gratuitous political gesture which would be taken by the Russians as a desire on our part to make 'cold war' propaganda." ${ }^{, 32}$ On the same point, Assistant Under-

${ }^{326}$ LAC, RG 76, Vol. 987, File IM 5782-1, Part 1. Memorandum for the Minister "Re: Czechoslovakian Refugees" from Deputy Minister of DMI Couillard, 4 September 1968; see also Memorandum to the Minister "Re: Czechoslovak Refugees" from Deputy Minister of DMI Couillard, 3 September 1968.

${ }^{327}$ LAC, RG 2, Series A-5-a, Vol. 6338. Cabinet minutes, 5 September 1968. 1-2; 8-9.

${ }^{328}$ Senator Andrew Thompson did embark on a "fact-finding mission" to Europe on behalf of MacEachen, but not until October, and with no intended publicity. See LAC, RG 25, Vol. 8908, File 20, Part 12. Halstead to Brown, concerning "Czechoslovak Refugees," 5 September 1968; See LAC, RG 76, Vol. 1401, File IM 5782-1, Part 8. Czechoslovakian Refugees. Implementation of Canadian Immigration Arrangements - Visit to Europe. Hon. Mr. Thompson. Debates of the Senate, Official Report (Hansard). 1st Session, $28^{\text {th }}$ Parliament, Vol. 117, No. 19, 23 October 1968; LAC, RG 76, Vol.1402, File IM 57821, Part 4. Message regarding "Czechoslovak Refugees" from External Affairs to Canadian High Commission, London, 9 October 1968. 
Secretary of State John Starnes criticized officials at the DMI for Bissett's failure to encrypt his instruction to Geneva. Knowledge of its contents by the Czechoslovakians and the Russians, he wrote, "could be politically embarrassing to the Canadian government.",329 As for the idea of sending a "talent team" to Europe, Cadieux once more made his reservations clear prior to the next meeting of cabinet. While at the official level, the DEA had indicated its sympathy with an effort to "ensure that Canada receive a good share of the most eminent refugees now outside of Czechoslovakia," sending a team to Vienna would tend to generate publicity which might be harmful to Canada's main, humanitarian purpose: “[S]uch activity, unless carefully handled, could be interpreted as profiting from the distress of another country, or as inciting Czechoslovak citizens to become refugees, i.e. encouraging the decapitation of Czechoslovak society of the very elements which can provide the liberal leadership it will require in the difficult years ahead." Cadieux added that "unofficial soundings" from Czechoslovak missions abroad appeared to agree. ${ }^{330}$

Several days later, for example, an official from the Czechoslovakian Embassy in Vienna told Ambassador McCordick that many of the Czechoslovakians currently outside the country were able, highly qualified people and very important to the future of his country. He and his government hoped that a large proportion of them would return, and "strongly expressed hope that [Canada] would not specifically grant political asylum to citizens of his country or even use this expression," which he said would "make things even more difficult for Czechoslovakians."331

${ }^{329}$ See LAC, RG 25, Vol. 8908, File 20, Part 12. "Memorandum for European Division and Consular Division" from John Starnes, 6 September 1968.

${ }^{330}$ LAC, RG 25, Vol. 8907, File 20, Part 3. "Memorandum for the Minister - Czechoslovak Refugees," from the Under-Secretary of State for External Affairs (initialed "M.C." at end), 9 September 1968.

${ }^{331}$ LAC, RG 25, Vol. 8908, File 20, Part 13. Message (888), Canadian Embassy, Vienna, to External Affairs, 17 September 1968. 
While several ambassadors had explicitly noted the "calibre" of potential migrants in their midst, DEA officials in Ottawa took their lead from their Under-Secretary on the issue of the refugee programme's humanitarian and economic purposes. The day before its final version was issued, a draft of the DMI's press release announcing the programme was discussed at an interdepartmental meeting. R.W. Murray of the DEA's European Division "voiced concern over the political implications" of including a reference to the special treatment Czechoslovakians inside Czechoslovakia were being given by Canada (those with close relatives in Canada who had permission from Czechoslovakian authorities to leave) in an announcement about a programme intended to assist refugees. DMI Assistant Deputy Minister Byrnes Curry and his Director of Information, B.M. Erb, told Murray that his point would be conveyed to MacEachen and Couillard, but that the concern of most Canadians would be for their relatives. Failure to mention their plight would undoubtedly lead to a flood of inquiries. ${ }^{332}$

At the same meeting, F.A. Milligan of the Canada Council advocated the dispatch of a talent team to Europe. No "recruitment" would be necessary, he said. Equipped with firm job offers to refugees, the team's "mere presence in Europe would be sufficient to attract interested applicants." Unless Canada acted quickly, such people might choose migration to other countries. Curry concurred the government itself should not be involved in such a "scheme." Otherwise, Canada would be open to the charge that it was taking advantage of the situation in Czechoslovakia to "skim the cream off the top." Milligan aside, the group agreed that the venture should proceed privately, leaving it to DMI staff

${ }^{332}$ LAC, RG 76, Vol. 987, File IM 5782-1, Part 2. Memorandum from the Head of Immigration Secretariat to the Assistant Deputy Minister (Immigration), containing resume of notes taken at the interdepartmental meeting on "Czechoslovak Refugees" (held Thursday, 5 September), 9 September 1968. 
abroad to handle the identification and selection of such individuals. Curry left the door open on a final decision. ${ }^{333}$ Bissett, meanwhile, could not have been clearer in his next set of instructions to Geneva:

You might want to have officers watch for any Czech refugees of outstanding qualifications i.e. artists, scientists, professors and have [their] particulars sent here so that confirmed employment might be arranged in advance. [I] understand [that the] Ford Foundation and others might be canvassing among refugees for outstanding talent. If we can come up with firm offers it might help Canada obtain some of these people. ${ }^{334}$

Cadieux's fears were further realized when, the next day, an ad hoc meeting was held in the Conference Room of the Canada Council to discuss the "identification and recruitment of Czechoslovakian refugees of exceptional qualifications." The meeting, chaired by Canada Council Director Jean Boucher, included representatives from the NFB, the National Arts Centre (NAC), the CBC, the National Research Council, the Department of Industry, and the Association of Universities and Colleges of Canada. Curry attended on behalf of the DMI. Murray once again represented External Affairs. ${ }^{335}$

Boucher mentioned that the Canada Council had been approached by a group of Czechoslovakian economists attending a conference in Montreal. This group, and others these scholars knew to be currently in Austria, wished to resettle in Canada and were interested in learning about employment opportunities. If such opportunities could be lined up in advance, perhaps Canada could better compete with other countries also seeking to

${ }^{333}$ LAC, RG 76, Vol. 987, File IM 5782-1, Part 2. Memorandum from the Head of Immigration Secretariat to the Assistant Deputy Minister (Immigration), containing resume of notes taken at the interdepartmental meeting on "Czechoslovak Refugees" (held Thursday, 5 September), 9 September 1968.

${ }^{334}$ LAC, RG 76, Vol. 987, File IM 5782-1, Part 1. Message from Joe Bissett, Chief of Operations, Foreign Branch, Immigration Service, Department of Manpower and Immigration (IMFOR), to Immigration (Geneva), 6 September 1968.

${ }^{335}$ LAC, RG 25, Vol. 8908, File 20, Part 12. "Minutes of an ad hoc meeting held in the Canada Council Conference Room on Saturday, 7 September 1968, to discuss the identification and recruitment of Czechoslovakian refugees of exceptional qualifications," 7 September 1968. 
attract Czechoslovakian talent. Boucher made clear that such efforts "would not involve any inducement for people to leave" their country, but thought it might be advisable to develop procedures for finding such outstanding people while they were still in Europe. ${ }^{336}$

Curry had changed his position, saying that his Department would welcome the help of a small team of people in Vienna. Murray expressed Cadieux's concerns. The policy of the government so far had emphasized the concept of a safe haven for those Czechoslovakians who had left their country as refugees. "They would not want to 'decapitate' Czechoslovak society or appear to exploit the difficulties now being experienced by that country." Boucher concurred, but at the same time said that: "the Canadian government may in the past have been too anxious to avoid giving the impression of special treatment for exceptional refugees and in the absence of some effort to supplement the general programme, the best of the refugees might be enticed to other countries which were acting more aggressively." 337

Hamilton Southam, Director General of the NAC, had already telegraphed both Couillard and Cadieux. The Centre was in the process of creating its national orchestra and was about to start auditions in Europe. He was ready to dispatch his Director of Music, Jean-Marie Beaudet, to Vienna to canvass the possibility of securing "first rate Czechoslovak instrumentalists" on behalf of other Canadian orchestras and followed up with Curry two days later. ${ }^{338}$

${ }^{336}$ LAC, RG 25, Vol. 8908, File 20, Part 12. "Minutes of an ad hoc meeting held in the Canada Council Conference Room on Saturday, September 7, 1968, to discuss the identification and recruitment of Czechoslovakian refugees of exceptional qualifications," 7 September 1968.

337 Ibid.

${ }^{338}$ Ibid; see also LAC, RG 25, Vol. 8908, File 20, Part 12. Letter from Southam to Curry, 9 September 1968. 
At the cabinet's second meeting on the programme, MacEachen told his colleagues that a quick funding decision was important to enable Canadian officials "to select the best of the refugees who wished to come to Canada." By this time, a more formalized programme for Canada's assistance to Czechoslovak refugees had taken shape. The Minister sought and received cabinet approval for $\$ 2$ million to cover its costs. MacEachen was conscious of the need for the government to keep the public promise Sharp had also made that the financial assistance provided would be the same as that received by Hungarian refugees in 1956. The existing Assisted Passage Loan Fund would not do, as it did not allow for the making of non-refundable grants. Charles Drury, the President of the Treasury Board, observed that the Loan Fund might actually be the preferred vehicle, given his impression that most of the refugees were "better able to repay assistance funds" than the "average" immigrant. Other ministers rebuffed this suggestion as both "morally and politically indefensible." Rather than "drawing...a distinction between current Czech refugees" and those who had arrived from Hungary in 1956 on the basis of their capacity to repay loans to the government, grants ought to provided. It was pointed out that the "quality of Czech refugees as potentially good Canadian citizens" would in fact make the grants "a good investment." 339

That the government saw an economic opportunity in this flow of what it and the nation's media were calling refugees was not hidden from the public. Its efforts in this regard could, however, have been communicated more effectively. Within a week of cabinet's approving of the initial refugee programme, MacEachen had also announced that a four-man team had been "brought together under government initiative" and sent to

${ }^{339}$ LAC, RG 2, Series A-5-a, Vol. 6338. Cabinet minutes, 10 September 1968. 4-5. 
Vienna to help facilitate the entry of "especially qualified" refugees already in Austria who might wish to come to Canada. Arriving in Vienna on 17 September, the team would "benefit from the many offers of assistance which have been made to the government by numerous public and private organizations and individuals in Canada." 340

The Star wrote that the country "apparently is setting out to recruit" some of Czechoslovakia's intellectuals that were in Vienna as refugees. There were "signs," it had observed in an earlier story, of "international competition for them because of their superior qualities." ${ }^{341}$ Australia had also initiated a special programme to deal with the Czechoslovakians, but the US had not. The Globe quoted a Canadian immigration official saying that "[f]or us it is an unprecedented opportunity to get the finest type of persons in a huge variety of fields." ${ }^{342}$ The DMI released the announcement about the four-man Vienna team before providing Cadieux with the opportunity to consider an advance draft "in the light of the various political implications which had been discussed at the interdepartmental task force." An apologetic Curry explained to the European Division's J.G.H. Halstead that External Affairs' interest in the release had been "overlooked in the last-minute confusion which attended its issuance." Two texts had been in "simultaneous preparation" and the version issued to the press was approved by Couillard without Curry's knowledge. ${ }^{343}$

${ }^{340}$ The four-man team consisted of Dr. J.D. Babbitt of the National Research Council, Dr. Andrew Rossos from Toronto's Centre for Russian and Eastern European Languages, Dr. Arnold Walter, former head of Toronto's Conservatory of Music, as well as Mr. G. Gagnon of the DMI. See LAC, RG 25, Vol. 8908, File 20, Part 13. Press Release, Office of the Minister of Manpower and Immigration, 17 September 1968.

${ }^{341}$ Rev. A.C. Forrest, "55 Czechoslovak refugees on flight bound for Montreal," Toronto Star, 11 September 1968, C1; C4; "Canada seeks Czech brains in Vienna," Toronto Star, 18 September 1968. A83.

${ }^{342}$ Reuters. "20-minute briefing each: Rush of Czech refugees handled in crash program," The Globe and Mail, 16 September 1968, A17; LAC, RG 76, Vol.1402, File IM 5782-1, Part 4. "Notes for Mr. Curry Re: Czechoslovak Refugee Paper," 3 October 1968.

${ }^{343}$ LAC, RG 25, Vol. 8908, File 20, Part 13. Memorandum regarding "Czechoslovak Refugees" from J.G.H. Halstead, European Division, to Under-Secretary of States for External Affairs, 18 September 1968. 
The mishap did not help the Canadian government's messaging. In the House of Commons, Conservative Member of Parliament George Hees asked MacEachen if Canada was seeking only the "cream of the crop" of those Czechoslovakians applying for entry into the country. The Minister replied that the refugee aid programme was available to all Czechoslovakians, and that in the case of the four-man team, expert advice on Canadian opportunities was being provided to those with scientific and other professional qualifications who might be interested. ${ }^{344}$

While the government insisted this was not a recruitment effort, the perception was a difficult one to avoid and had international implications. Cadieux, who had warned of this problem, was now trying to fix it. Neutral Austria, for one, was not pleased. Reading about Canada's efforts in the morning newspapers, the Austrian ambassador called Cadieux "in a highly agitated state." Not only was he concerned that such an effort should be undertaken without informing the Austrian government, but also that the USSR and its allies, "who had already complained on numerous occasions that Austria was not maintaining its neutrality, would seize on this occasion." Hinting that the interdepartmental liaison in Ottawa had been "less than perfect," Cadieux told the ambassador that it had been "a regrettable oversight" that the Canadian Government had not informed him of the initiative. He also re-iterated that the team would not be actively recruiting or carrying out any publicity campaign, but merely "facilitating processing of immigration applications, particularly from those with special professional qualifications." While pointing out that the official press release had been careful not to talk of "recruiting" but of "assisting"

\footnotetext{
${ }^{344}$ Canadian Press. "Czech ‘cream' allegation is denied," The Globe and Mail, 20 September 1968, A4.
} 
Czechoslovak refugees already in Vienna, he assured the ambassador that Canada would nevertheless take steps to correct any "false impression" in the media. ${ }^{345}$

Cadieux dispatched Halstead to communicate their diplomatic concerns - as well as their displeasure about process - with Curry. Halstead reported back to Cadieux that Curry had given him "a very complicated account of what had happened, which I will not bore you with." The two had agreed on a subsequent media strategy, and that Sharp and MacEachen should confer on the matter. Curry told Halstead that he and his colleagues had been working under tremendous pressure in the last few days. "Incidentally," Halstead added, "Mr. Couillard has since gone into the hospital."346

Cadieux and Halstead were not the only officials concerned with the four-man team. Ambassador McCordick wrote from Vienna that he was not surprised by the Austrian Ambassador's reaction in Ottawa. "I must confess to have been a trifle irked," he wrote after learning about the team's existence just two hours before it had arrived in Vienna: "If I had been consulted in advance, I would have warned that it was to be a matter of walking on eggshells and of being very careful to avoid the slightest resemblance to ambulance chasers." ${ }^{347}$ Even amongst DMI officials, opinions were mixed on the notion. "We don't think much of your talent scout idea and feel it is a mistake," MacWilliam wrote Bissett from Geneva. “But I haven't been asked to comment on the proposal so won't comment further." For the record, Bissett made a point of scribbling on a copy of the telex that the

${ }^{345}$ LAC, RG 25, Vol. 8908, File 20, Part 13. Message (S-995) regarding "Czechoslovak Refugees," UnderSecretary of State for External Affairs Cadieux to Canadian Embassy, Vienna, 18 September 1968.

${ }^{346}$ LAC, RG 25, Vol. 8908, File 20, Part 13. Memorandum regarding "Czechoslovak Refugees" from J.G.H. Halstead, European Division, to Under-Secretary of States for External Affairs, 18 September 1968.

${ }^{347}$ LAC, RG 25, Vol. 8908, File 20, Part 13. Message (905), Canadian Embassy, Vienna, to External Affairs, 19 September 1968. 
"talent scout [was] not [a] Foreign Branch idea but was considered by [the] D.M. and Minister as [a] desirable gesture."348

As McCordick observed, the team arrived with "considerable misapprehensions," expecting to find officials ready and waiting with "lists of world famous scientists[,] musicians and artists." The group had made it clear to the ambassador that "they only had top people with international reputations in mind." Realizing that such lists did not exist or "could conceivably have been prepared," the group asked if McCordick could, on its behalf, make enquiries through his contacts in Vienna. He explained "how delicate all this was," and did not think he could take the matter up with any Austrian official. One wellconnected contact with whom he could "take discreet soundings" was, as it turned out, out of town for the month. In light of the incident with the Austrian ambassador in Ottawa, McCordick wrote that "I doubt if I should take any personal action at all."349

The work of visa officers in Vienna was given an added layer of complication by the various requests, typically forwarded to the embassy by the government apparatus at home, to provide assistance to individuals or groups lobbying for the processing of a specific individual or type of migrant. These requests were hardly in aid of frightened refugees desperate to flee the country, but rather concerned people whose needs were, Zawisza recalls, "usually peripheral" to the more pressing application cases in hand. He describes going out of his way to establish contacts in Vienna who might help him "open

\footnotetext{
${ }^{348}$ LAC, RG 76, Vol. 987, File IM 5782-1, Part 2. Message from Immigration (Geneva), concerning "Czech Refugees" to DMI (Ottawa), 12 September 1968.

${ }^{349}$ LAC, RG 25, Vol. 8908, File 20, Part 13. Message (905), Canadian Embassy, Vienna, to External Affairs, 19 September 1968.
} 
the right doors" for various representatives and prospective employers from Canada who were showing up in search of a specific kind of migrant from Czechoslovakia. ${ }^{350}$

The added workload was beginning to take its toll. MacWilliam wrote to Ottawa that the situation in Vienna "continues to be tense and I am more than concerned for the health of the staff." They were working day and night trying to keep up and had virtually no room for more personnel even if they could get it. Yet "representations continue to pour in from your end concerning individual Czech refugees which you will appreciate are difficult to deal with." 351

Notwithstanding efforts by the Canadian media to portray the situation differently, the Czechoslovakians in 1968 were a unique sort of refugee. Journalists on the ground were seen to ignore the more typical cases of Czechoslovaks mulling over their migration options in favour of stories that fit a more humanitarian narrative. ${ }^{352}$ Canada's ambassador to Vienna characterized the state of mind of the Czechoslovakians he was seeing at the time as "typified by wavering, confusion, and doubt." The Czechoslovakian official he had spoken to in the midst of Canada's refugee processing effort there thought that most of his countrymen opting to emigrate to Canada and elsewhere were "reacting over-hastily" and had not fully thought out the consequences of their decision. ${ }^{353}$

However, that same official told McCordick that those returning to Czechoslovakia would face risks - "the same risks as the fourteen million people who are there." As long

350 John Zawisza, "Processing of the Czechoslovakian Refugee Movement: Vienna, Austria (Sept-Nov. 1968)," C.I.H.S. Bulletin: no. 46 (July, 2005): 7.

351 LAC, RG 76, Vol.1402, File IM 5782-1, Part 3. Message (1775) concerning “Czech Refugees" from Immigration (Geneva) to Immigration (Ottawa), 17 September 1968.

352 John Zawisza, "Processing of the Czechoslovakian Refugee Movement: Vienna, Austria (Sept-Nov. 1968)," C.I.H.S. Bulletin: no. 46 (July, 2005): 7.

${ }^{353}$ LAC, RG 25, Vol. 8908, File 20, Part 13. Message (888), Canadian Embassy, Vienna, to External Affairs, 17 September 1968. 
as it was possible for Czechoslovakians to "run their own shop," there would be no reprisals or arrests for political reasons. Yet, if the occupying authorities were sufficiently dissatisfied, "there would be no guarantees for anyone." 354 Indeed, Ambassador Williams in Belgrade reported that many of the cases being interviewed in Belgrade had managed to get out of Czechoslovakia as tourists after the invasion or the so-called "Moscow Diktat." They were not simply persons stranded outside their country by the events that had taken place, but, "like the Hungarians, refugees fleeing the Soviet subjugation of their country." 355 In his retrospective account, Zawisza suggests that the Czechoslovakians being assisted were indeed "involuntary migrants" and that leaving Czechoslovakia was a difficult decision. "Many of our applicants," he recalls, "wondered how hard would the hardening be."356

This included Czechoslovakian employees of the Canadian Embassy in Prague. An office driver who had fled shortly after the invasion opted to return, but, of four office workers who had been on staff in July, only one remained by the end of October. She was nervous and unhappy, wrote Chargé d'affaires Cole, and would leave soon if she could persuade her husband to do so. The Embassy's receptionist was vacationing in Britain and had indicated before she left that there was only a slim chance that she would return. After hearing a discouraging media report about future travel restrictions, a temporary receptionist said that he too would be advancing his plans for emigration to Canada. ${ }^{357}$

${ }^{354}$ LAC, RG 25, Vol. 8908, File 20, Part 13. Message (888), Canadian Embassy, Vienna, to External Affairs, 17 September 1968.

${ }^{355}$ LAC, RG 76, Vol. 987, File IM 5782-1, Part 2. Message (855), Canadian Embassy, Belgrade to External Affairs and DMI (Ottawa), 1 September 1968.

356 John Zawisza, "Processing of the Czechoslovakian Refugee Movement: Vienna, Austria (Sept.-Nov. 1968)," C.I.H.S. Bulletin: no. 46 (July, 2005): 7.

${ }^{357}$ LAC, RG 25, Vol. 8908, File 20, Part 15. Message (1094), Cole to External Affairs, 28 October 1968; LAC, RG 25, Vol. 8908, File 20, Part 16. Message (1155), Cole to External Affairs, 13 November 1968. 
The recollections of the visa officers in Vienna suggest that they thought their effort was helping people in legitimate need. ${ }^{358}$ It was a sentiment shared by other Canadians. On a flight he happened to be on out of Ottawa, Guelph University's Music Director Nicholas Goldschmidt met a plane load of some sixty Czechoslovakian refugees who had just arrived in Canada. Having made a point of talking to as many of them as possible, he was moved to send a letter to Sharp. "[T]hese distressed people," he wrote, "could not have said anything more wonderful and flattering" about the treatment they had received from staff in Vienna. ${ }^{359}$

On 8 September, some of the first refugees from Czechoslovakia began to arrive, Canada becoming the first country outside of Europe to admit them. ${ }^{360}$ Nine Czechoslovaks - two families and two students, all of whom had been vacationing outside of Czechoslovakia when it was invaded - were greeted that night by MacEachen's parliamentary secretary at the Montreal airport. Another 32 were expected to arrive the next day. ${ }^{361}$ The day before the Throne Speech on 12 September, Trudeau announced the cabinet's decision to create the initial, $\$ 2$ million fund to assist Czechoslovakian refugees as part of its efforts to "[clear] the way for mercy flights to bring up to 1,000 Czechoslovak refugees to Canada during the next 10 days." 362

${ }^{358}$ See Maria Beaulne, "68 Czech Experience." C.I.H.S. Bulletin, no. 46 (July, 2005): 9-10; Mike Molloy, "Vienna 1968: discovering the world." C.I.H.S. Bulletin, no. 46 (July, 2005):15; Joyce Cavanagh-Woods, "Vienna." C.I.H.S. Bulletin, no. 46 (July, 2005): 10-11.

${ }^{359}$ LAC, RG 76, Vol.1402, File IM 5782-1, Part 4. Letter from Nicholas Goldschmidt to Mitchell Sharp, 2 October 1968.

${ }^{360}$ LAC, RG 76, Vol.1402, File IM 5782-1, Part 4. "Notes for Mr. Curry Re: Czechoslovak Refugee Paper," 3 October 1968.

${ }^{361}$ Salwyn, Andrew, Czechs arrive in Montreal; 'We all love Dubcek'," Toronto Star, 9 September 1968, A28.

362 Ottawa Bureau, "\$2 million fund set up to fly in 1,000 Czechs.” The Globe and Mail, 12 September 1968. A8. 
The Soviet invasion of Czechoslovakia did not figure prominently or dramatically in the Throne Speech. Regarding the refugee effort, the Governor-General duly reported to Parliament that "my ministers have already taken steps to offer permanent homes in Canada" to Czechoslovakians seeking refuge from their invaded country. ${ }^{363}$ Days later, in an editorial headlined "Their arrival honors us," the Globe wrote that "Prime Minister Pierre Trudeau and External Affairs Minister Mitchell Sharp, after a brief hesitation, have moved swiftly to help Czechoslovak refugees settle here."364 From Geneva, MacWilliam observed that despite some initial challenges, the general situation in Europe was under control and seemed to be stabilizing. "From time to time," he wrote, "papers cross my desk insinuating that Canada has been slow in reacting to the crisis. I do not share this view." With the UNHCR [UN High Commissioner for Refugees] and others, "our stock is high."365

Sweetening the Deal

In Vienna, where the effort would continue through to November, Canada was processing applicants from start to finish in two-to-three weeks, a timeframe that would lengthen somewhat as the volume of applications grew. ${ }^{366}$ Three or four Air Canada charters would be filled each week. ${ }^{367}$ David Bullock, the Immigration Affairs Attaché stationed in The Hague who was seconded to Vienna to help Zawisza, described the team

\footnotetext{
363 "Here is the text of the Governor-General's Throne Speech," Toronto Star, 12 September 1968.

364 "Their arrival honors us," The Globe and Mail, 17 September 1968. A6.

365 LAC, RG 76, Vol. 987, File IM 5782-1, Part 2. Immigration (Geneva) to DMI (Ottawa), 11 September 1968.

366 John Zawisza, "Processing of the Czechoslovakian Refugee Movement: Vienna, Austria (Sept.-Nov. 1968)," C.I.H.S. Bulletin, no. 46 (July, 2005): 8; David Bullock, “The Czechoslovak Refugee Movement of 1968: Some Personal Reminiscences.” C.I.H.S. Bulletin, no. 46 (July, 2005): 8-9.

${ }^{367}$ Mesheau, Daryl. Untitled. C.I.H.S. Bulletin, no. 46 (July, 2005): 12-13.
} 
of visa officers assembled in Vienna as a "processing "machine"" that was soon "churning out" thousands of immigrants "of the highest potential.",368

By mid-September, with word spreading inside and outside of Czechoslovakia that Canada would accept all refugees who applied, the Vienna office was "calling up" 150 cases per day and was booked through to the end of the month. At one point, the embassy in Prague reported that a weekly Czech newspaper contained a brief article that Canada was arranging one-year courses in the Alps with four English lessons daily, free departure to Canada, and the possibility of definite work. Staff proposed writing a correction to the paper. ${ }^{369}$ MacWilliam told Bissett that "we will be in business for a long time." 370

From his insider's perspective, Bissett writes that the Czechoslovakian refugee movement was a highly successful undertaking by the new DMI, "a challenge well met."371 This view, while no doubt shared by some of his ambassadors in Europe, would not have been shared by Cadieux. What had begun as a humanitarian response two days after the invasion had become a programme openly questioned in Canada's Parliament for its apparent, self-interested, economic aims.

That fall, Canada was doing what it could to sweeten the deal for potential Czechoslovak applicants. The DMI consolidated offers of jobs and free tuition made by employers and universities across the country. This information was sent to its regional offices in Geneva and London, who in turn passed it on to applicants in the midst of

${ }^{368}$ David Bullock, "The Czechoslovak Refugee Movement of 1968: Some Personal Reminiscences." C.I.H.S. Bulletin, no. 46 (July, 2005): 8-9.

${ }^{369}$ LAC, RG 76, Vol.1402, File IM 5782-1, Part 3. Message (982), Embassy, Prague to External Affairs, 1 18 September 1968.

${ }^{370}$ LAC, RG 76, Vol.1402, File IM 5782-1, Part 3. Memorandum re: "Possible Cut-off Date for Czechoslovak Refugees," Director, Foreign Branch (Immigration) to Assistant Deputy Minister (Immigration), 17 September 1968.

${ }^{371}$ Joe Bissett, "The Czechoslovakian Refugee Movement, 1968," C.I.H.S. Bulletin, no. 46 (July, 2005): 4. 
decision. "The University of Alberta has offered places to six refugee students," reported the Director of Foreign Branch 'B' from London. "This offer is being brought to the attention of suitable candidates." The status of applicants who had yet to be granted visas was, wrote the Director, "dependent upon further action by the refugees concerned." 372

With much of the \$2 million fund for the transportation and settlement of Czechoslovakian refugees remaining unspent, cabinet approved MacEachen's recommendation on 3 October that assistance be made available to refugee students, as well as to others in need of language training. The government, it was argued, had a moral obligation to help these refugees maintain their status as students, and had provided similar assistance to Hungarian students in $1956 .{ }^{373}$

The government was on the defensive against suggestions from the Opposition in the House of Commons that Canada might be unduly taking the initiative to attract or induce Czechoslovakians to Canada. Czechoslovakian dentists arriving in Canada through the programme felt unfairly "encouraged" after their professional qualifications were not recognized. Officials advised MacEachen to say in another case that the Government "feels morally obliged to accept such applications when they arise spontaneously," wherever they may be received. ${ }^{374}$

${ }^{372}$ See LAC, RG 76, Vol. 987, File IM 5782-1, Part 6. Extract from letter concerning “Operational Report: September 1968 - Region 'B' from the Director of Foreign Branch 'B' to Director of Foreign Branch, Ottawa, Records Management - Immigration, Department of Manpower and Immigration, 8 October 1968; Memorandum regarding "Opportunities for Czech Refugees" from A.A. Ewen, Co-ordinator, Czech Refugees, Manpower Utilization Branch, to Chief of Operations, Foreign Branch, DMI, 11 October 1968; Message regarding "Opportunities for Czech Refugees" from Director, Foreign Branch to Directors, Region 'A' Ottawa, Region 'B' London, Region 'C' Geneva, DMI, 15 October 1968; Report regarding "Offers of Assistance to Czechoslovak Refugees - September 3 to October 11, 1968" (including attached appendices 'A' and 'B'), from A.A. Ewen, Co-ordinator, Czech Refugees, Manpower Utilization Branch, to Director General of Operation, DMI, 15 October 1968.

${ }^{373}$ LAC, RG 2, Series A-5-a, Vol.6338, Cabinet minutes, 3 October 1968. 8-11.

374 Conservative MP Robert Thompson of Red Deer questioned MacEachen about whether immigration officers had advised Czechoslovakian dentists before they immigrated to Canada that their professional qualifications would not automatically be accepted in Canada without some retraining. Asked by 


\section{"This is a tough one"}

The same moral obligation, however, did not apply to all groups. The nonhumanitarian aspect of Canada's refugee response was particularly evident in the dilemma posed for its officials in dealing with "two entire tribes" of "gypsies" from Czechoslovakia. MacWilliam wrote that the "[a]pplicants do not of course identify themselves as Gypsies and their upbringing and moral code permits and even encourages misrepresentation to what they call the white men. Marriage as such is a passing thing and progeny belong to the group rather than to the couple responsible." ${ }^{375}$ The two groups were being supported in Austrian camps and were applicants for asylum there. They were apparently separate from other camp residents on "account [of] their bevaviour and morals." "Advise soonest you approve their processing," read MacWilliam's initial communication. "To the best of my knowledge they are like most Gypsy groups, illiterate and without occupations."376

Geneva thought it "most doubtful" that many of the "gypsies" could meet the “normal immigration selection criteria." However, under Canada's more relaxed policy for Czechoslovakian refugees, they could most certainly qualify. "We need to give guidance

\footnotetext{
MacEachen to follow up on the matter, Curry told his Minister that "[w]e are aware of the difficulties that immigrant dentists face in Canada...I am confident that the five Czech refugee dentists [in question] were told that they would not likely meet Canadian requirements but I shall advise you further when I receive a report from Vienna." The next day, Curry informed MacEachen that, in fact, applicants were required to sign a statement to that effect, and that the one dentist whose name had been identified in the matter had done so. The Department had his statements on file. See LAC, RG 76, Vol. 987, File IM 5782-1, Part 6. Page excerpt from Commons Debates, page 986, 9 October 1968; Memorandum to the Minister, DMI, 11 October 1968; Memorandum to the Minister regarding "Czech Dentists" signed (stamped) by R.B. Curry for the Deputy Minister, 15 October 1968; Memorandum to the Minister regarding "Dentists from Czechoslovakia" signed (stamped),by R.B. Curry for the Deputy Minister, 16 October 1968.

375 LAC, RG 76, Vol.1401, File IM 5782-1, Part 8. Message (2212), regarding "Gypsis [sic] in CR Movement," Immigration (Geneva), to DMI (Ottawa), 28 October 1968.

${ }^{376}$ LAC, RG 76, Vol.1401, File IM 5782-1, Part 8. Message (2150), Immigration (Geneva) to DMI (Ottawa), 22 October 1968; Message (2164), regarding "Gypsies in CR Movement," Immigration (Geneva) to DMI (Ottawa), 23 October 1968; Message (2212), regarding "Gypsis [sic] in CR Movement," Immigration (Geneva) to DMI (Ottawa), 28 October 1968; Memorandum regarding "Czechoslovak Refugees" Bissett to Beasley, 28 October 1968.
} 
to our office as to how to deal with them," wrote Bissett. "This is a tough one. If we refuse, we can be charged with discrimination, if we accept, we'll have a real problem in Canada trying to establish these people." 377

The way out settled on - one which might enable Canada to avoid the perception of discrimination even if it existed - was language within the standing refugee policy that individual visa officers, could, at their own discretion, interpret and apply in an interview. A specific passage highlighted by Bissett indicated that refugees were required to "have the personal qualities necessary to become established." He advised Curry that the Vienna office could "quite properly refuse" any refugee who in the opinion of the officer did not meet this criterion. Bissett would, however, make it clear in his instructions back to Geneva that "gypsies are to be dealt with in the same manner as other refugees, i.e. they are not to be refused simply because they are gypsies and any who are able to meet our reduced selection criteria are to be allowed forward." Nonetheless, the group had been singled out for special scrutiny. "I am not aware," noted Bissett, "of any Czech refugee who has been refused because of inability to meet our reduced selection criteria." ${ }^{378}$

\section{"Discriminatory Shoppers": Ending the Programme}

By October, officials at both the DEA and the DMI began weighing the pros and cons of continuing the special programme for Czechoslovakian refugees. MacWilliam suggested that it might be time to consider a cut-off date. "It seems to me," he wrote

377 RG 76, Vol. 1401, File IM 5782-1, Part 8. Message (2150), Immigration (Geneva), to DMI (Ottawa), 22 October 1968; Message (2164), Immigration (Geneva) to DMI (Ottawa), 23 October 1968; Message (2212), Immigration (Geneva) to DMI (Ottawa), 28 October 28 1968; Bissett to Beasley, 28 October 1968 .

${ }^{378}$ LAC, RG 76, Vol.1401, File IM 5782-1, Part 8. Memorandum regarding "Gypsies - applying in Vienna as Czechoslovak Refugees" from Director, Foreign Branch to Assistant Deputy Minister (Immigration), 29 October 1968. 
Ottawa, "that a point will be reached where we may be overdoing our help." Applicants were being called for interviews but not showing up, or returning after accepting a destination other than Montreal or Toronto to request that their destination be changed. "They are very discriminatory shoppers," he observed, "and seem to have got the impression that we need them and are actively recruiting skilled labour."379

Despite the economic orientation of its refugee programme, officials emphasized to the end that Czechoslovakian authorities were grateful for the sensitive balance that Canada had tried to strike. They even expressed concern about how ending the programme might impact any liberal hopes for Czechoslovakia:

All indications received indicate that Czechoslovakia appreciates the humanitarian, non-aggressive approach we have taken to the refugee problem, and have accepted this as a concrete indication of our moral support. Cancellation of the program would be seen as pressure on Czechoslovak citizens at home and abroad to make their decision for or against the courageous contention of their leaders that they can save something of value from the wreckage of the invasion. ${ }^{380}$

At the same time, Czechoslovakia's authorities were sounding increasingly less liberal. Its embassy in Ottawa attempted to secure Canada's help facilitating a "pick up" flight of refugees who, according to the embassy, wished to return home from Canada. Canadian officials were not keen on the idea. "We would not want to assist Czechoslovakia in a propaganda campaign," Curry wrote, "or in bringing pressure to bear on these refugees." "381

379 LAC, RG 76, Vol.1402, File IM 5782-1, Part 3. Message (1875), regarding "Czech Refugees," Immigration (Geneva) to DMI (Ottawa), 25 September 1968.

${ }^{380}$ LAC, RG 76, Vol. 987, File IM 5782-1, Part 6. Memorandum to the Minister regarding "Possible Modifications of Czechoslovak Refugee Program" signed (stamped) by R.B. Curry for the Deputy Minister, 15 October 1968.

${ }^{381}$ LAC, RG 76, Vol. 1401, File IM 5782-1, Part 5. Memorandum regarding "Return of Czech Refugees" from R.B. Curry, Assistant Deputy Minister, Immigration, to Under-Secretary of State for External Affair, 29 November 1968. 
Political and economic self-interest continued to be considered in the matter of when the phase-out should begin. Sharp re-iterated the importance of not announcing any "cut off" date too soon in a letter to MacEachen. "Dates have a way of leaking out and dramatizing events which otherwise - as in the case of the first step in the phasing-out process - would in themselves not be newsworthy." 382 MacEachen was also advised by his department that "[e]ditorial comment and news stories in the French and English press have been almost entirely sympathetic." Ending the programme now would not be in keeping with Canada's humanitarian commitment and "would evoke strong criticism from the Canadian public." In addition, the memo continued, "[w]e are getting well qualified people." An analysis of 400 landing records indicated that $82.5 \%$ of them were skilled workers, 20\% higher than comparable figures for workers coming into Canada in 1968 through the regular immigration movement. "The continuing influx of qualified refugees would help improve the annual total." 383

There was, by now, a clear acknowledgement internally that these were not "normal" refugees. Couillard told MacEachen that "[i]t would appear that while Canadians believe there is a refugee crisis, in fact few refugees themselves behave as though there was any urgency in fleeing their country." 384 There was little evidence that a crackdown on Czechoslovakia's liberal elements had taken place. While the threat continued to be posed as long as the country was still occupied, it was concluded that "the fears of political

382 LAC, RG 76, Vol.1401, File IM 5782-1, Part 7. Sharp to MacEachen, 3 October 1968.

${ }^{383}$ LAC, RG 76, Vol. 987, File IM 5782-1, Part 6. Draft memorandum regarding "Factors in Favour of Continuing the Special Program"; see also page 3, "Factors in Favour of Ending the Special Program", 11 October 1968; Memorandum regarding "Memorandum to Minister on Czechoslovakian Refugee Program" from the Acting Director, Programs and Procedures Branch, DMI, to A.D.M. (Immigration), 11 October 1968; Memorandum to the Minister regarding "Possible Modifications of Czechoslovak Refugee Program" signed (stamped) by R.B. Curry for the Deputy Minister, 15 October 1968.

${ }^{384}$ LAC, RG 76, Vol.1402, File IM 5782-1, Part 3. Memorandum to the Minister regarding "Czechoslovak Refugees" from Deputy Minister L.E. Couillard, 15 October 1968. 
persecution which sparked Canada's humanitarian response have so far not been realized." There was "[n]o doubt many of those who are leaving Czechoslovakia now are economic, rather than political refugees." If the flow of people leaving their country continued, Canada would at some point have to set a limit on how many it would accept. While the recommendation by mid-October was to sustain the movement further, officials began to contemplate what the phase-out would look like. This could include applying "the normal refugee criteria" to the Czechoslovakians: "We would deal only with those refugees on a priority basis who can demonstrate that there is a genuine danger of persecution if they were to return home." 385

Officials were looking forward to the programme's completion. If it could "die a natural death," wrote Bissett, the Canadian government could avoid the politically more difficult route of cutting it off. ${ }^{386}$ As Czechoslovakia announced the imposition of more travel restrictions on its citizens, Geneva suggested in mid-November that this might "spell the early termination" of the refugee movement from Vienna. Bissett forwarded the message on to a colleague, L.P. McCloskey, with a hand-written note: "It would appear the end may be drawing near." "Good news," McCloskey wrote to another. ${ }^{387}$

MacWilliam was recommending that "some form of higher selection standards" be applied. Not only were there indications that the movement was beginning to decline; there

${ }^{385}$ LAC, RG 76, Vol. 987, File IM 5782-1, Part 6. Draft memorandum regarding "Factors in Favour of Continuing the Special Program"; see also page 3, "Factors in Favour of Ending the Special Program", 11 October 1968; Memorandum regarding "Memorandum to Minister on Czechoslovakian Refugee Program" from the Acting Director, Programs and Procedures Branch, DMI, to A.D.M. (Immigration), 11 October 1968; Memorandum to the Minister regarding "Possible Modifications of Czechoslovak Refugee Program" signed (stamped) by R.B. Curry for the Deputy Minister, 15 October 1968

${ }^{386}$ LAC, RG 76, Vol.1401, File IM 5782-1, Part 7. Memorandum re: "Czechoslovak Refugees," Bissett to Beasley, 28 October 1968.

387 The hand-written notes were written on Action Request slips attached to the telex from Geneva. See LAC, RG 76, Vol.1401, File IM 5782-1, Part 5. Immigration (Geneva) to DMI (Ottawa), 14 November 1968. 
was a "deterioration in the quality of the refugees applying." Notably, Curry told Couillard that this was in itself not a good reason to change the criteria. He advised that "the decision that Canada would accept Czechoslovak refugees was taken without regard to the qualifications these people might or might not have; it was in effect a political decision. I doubt, therefore, that at this stage we should change any of the terms or conditions under which Czech refugees are being selected." 388

The fact that there was an apparent "deterioration" in the "occupational quality" of the most recent applicants was seen, at least internally, as a key argument to discontinue the programme by year's end. An ultimately deleted paragraph in a cabinet memorandum presented to MacEachen for his approval on 5 December stated that "there is little economic advantage in the continued admission of Czechoslovakians under the present policy. While an analysis of the occupations of the first arrivals showed them to be unusually qualified in terms of skill, a recent analysis of later arrivals shows that the skill composition of the group is no better than the regular immigration movement." 389

Together with its increasing costs, the primary reason put forward to cabinet for the refugee programme's termination was that the continuing flow of Czechoslovakian immigration was not the result of people "fleeing from actual persecution." This was odd, since that had never actually been the criterion. The cabinet was reminded that the decision to admit Czechoslovakian refugees under special arrangements was prompted by the belief

${ }^{388}$ LAC, RG 76, Vol.1401, File IM 5782-1, Part 5. Memorandum regarding "Czechoslovak Refugee Movement" from Assistant Deputy Minister (Immigration) to Deputy Minister, 1 November 1968.

389 This original memo was subject to further edits before the final version was sent to the Privy Council for the Cabinet's 19 December 1968 meeting. See LAC, RG 76, Vol.1401, File IM 5782-1, Part 7. Memorandum to the Cabinet regarding the "Phase out of Special Czechoslovakian Refugee Movement and Provision of Additional Funds for the Transportation and Settlement of the Refugees," for submission by Allan J. MacEachen, Minister of Manpower and Immigration, 5 December 1968 (attachment to Memorandum to the Minister regarding "Phasing out of the Czechoslovakian Refugee Movement," from W.R. Dymond, Acting Deputy Minister, 4 December 1968). 
that the occupation of their country by the Soviets would "result in repressive measures being applied to the liberal elements of the population." Three months later, there was still "little evidence of persecution taking place." By that point, 6,500 refugees from Czechoslovakia had arrived in Canada. The original estimate of 2,000 had been based on the assumption that Czechoslovakia's frontiers would be closed shortly after the invasion, and that applicants for migration to Canada would come largely from those Czechoslovakians who had been outside of their country at the time of the invasion. It was now possible that thousands more refugees could enter the country under the programme, even if it were to conclude by 31 December. Cabinet was told that $\$ 3.6$ million in new funding was required to cover its costs. ${ }^{390}$

At its 19 December 1968 meeting, MacEachen told cabinet that he planned to announce the programme's termination in the House of Commons the next day. "The government had a good story to tell of its efforts in this field," MacEachen said to his colleagues, "and he wanted to publicize it." It was agreed, however, that the announcement should be put off until the New Year. At the same time, cabinet allocated the additional funds requested to assist an estimated 10,000 Czechoslovakian refugees. ${ }^{391}$

On 3 January 1969, the DMI issued a statement that the programme would be discontinued. The government was satisfied that the initiative had enabled it to deal with the situation "in a manner of which all Canadians can be proud." After 10 January,

390 LAC, RG 76, Vol.1401, File IM 5782-1, Part 7. Memorandum to Cabinet regarding the "Special Czechoslovakian Refugee Program," submitted by Allan J. MacEachen, Minister of Manpower and Immigration, 16 December 1968; Memorandum to the Cabinet regarding the "Phase out of Special Czechoslovakian Refugee Movement and Provision of Additional Funds for the Transportation and Settlement of the Refugees," for submission by Allan J. MacEachen, Minister of Manpower and Immigration, 5 December 1968 (attachment to Memorandum to the Minister regarding "Phasing out of the Czechoslovakian Refugee Movement," from W.R. Dymond, Acting Deputy Minister, 4 December 1968).

${ }^{391}$ LAC, RG 2, Series A-5-a, Vol. 6338. Cabinet minutes, 19 December 1968. 9. 
Czechoslovaks applying as refugees would be considered "under the normal refugee selection criteria." The minister was "happy to underline the fact that Canadians generally have given this humanitarian program full support and a good deal of concrete assistance." At the same time, his statement cited a survey indicating that the skill and educational levels of the refugees were above the average of the "regular immigration flow." He was confident that they would "make a valuable contribution to the economic, social and cultural development of Canada." 392

13,000 Czechoslovakians would arrive in Canada between 1968 and 1969. ${ }^{393}$ Dubcek would hold on in Prague until the spring. He was ousted from power by the Soviets on 17 April $1969 .{ }^{394}$

392 The DMI would wrap up the programme in the ensuing months. See LAC, RG 25, Vol. 8908, File 20, Part 16. Message regarding "Termination Special Refugee Programme" (Numbers S-54), External Affairs to Prague, 8 January 8 1969; LAC, RG 76, Vol.1401, File IM 5782-1, Parts 9-10; File IM 5782-1, Vol.1402, Parts 11-12.

${ }^{393}$ Bothwell, Alliance, 284.

${ }^{394}$ New York Times Service, "Soviets force Dubcek ouster," The Globe and Mail, 18 April 1969, A1. 


\section{Conclusion}

As with the formulation of any foreign policy, underlying Canada's response to the Soviet invasion of Czechoslovakia were differences of opinion on what approaches best served Canada's interests, and to what extent these should, in this case, take into account the interests of Czechoslovakia. One internal disagreement in particular - that concerning "refugees" and the impact Canada's actions would have on the future of Czechoslovakian society - most colours the appraisal of the Canadian reaction. Even if one accepted that this was, ultimately, Czechoslovakia's crisis rather than Canada's, the least Canada could do was not make things worse. Yet it arguably did. This was a sign of an inexperienced government in the throes of its first East-West challenge.

More delusory thinking, and differences in approach, were at work that summer, beginning on the first night of the crisis. From the start, Minister Sharp could have been more punishing in tone towards the Soviets, more sympathetic to their victims. He chose, instead, a milder reaction. Afterwards, he explained that he wanted to reassure potentially panicked Canadians that the "third world war" was not about to start. ${ }^{395}$ This was, after all, merely a "row within the Communist bloc." "396 The cabinet, and the DEA, quickly determined the need for action, attaching great purpose to the appearance of Canadian initiative, however fruitless, at the UN. Cadieux's officials gave the government advice about actions that "no doubt would be applauded by public opinion in Canada and the

\footnotetext{
395 Ottawa Bureau, "Sharp promises Czech refugees ready welcome," The Globe and Mail, 23 August 1968. A9; Ottawa Bureau, "Canada will welcome Czech refugees: Sharp," Toronto Star, 22 August 1968, C1. 396 "It'll set our relations back years says Sharp of Soviet invasion," Toronto Star, 21 August 1968, A1.
} 
Western world." ${ }^{397}$ In the imaginings of Pravda, Cadieux's man in New York became the West's “marksman,"398 and, at least in Ignatieff's own view, a national "celebrity."399

Prime Minister Trudeau had little time for this particular sort of drama, but he had dreams of his own. He desired to go farther, and faster, on a more far-reaching aim, and a different stage. He would use the occasion of the Czech crisis to preach his own prescription for change in the Cold War world order - to lecture one, if not both, superpowers for their "slow thinking." "400 This meant challenging not only the Soviet Union, but also the US. His government would stand up to the Soviets for their obvious aggression, but also resist America's urging for a hardening of its position vis-à-vis NATO.

The invasion laid bare emerging differences between Trudeau and Cadieux about the pace at which a thawing of East-West relations should be pursued - and more misinterpretations. Putting Canada's longer-term security interest first, Trudeau and Sharp still spoke of accelerating détente despite Soviet behaviour towards Czechoslovakia. A setback, yes, but this invasion of a sovereign country did not somehow constitute a more serious roadblock. The Soviet Union was in the process of crushing liberalization in Czechoslovakia, yet a pathway towards détente still seemed clear to the Trudeau government. Cadieux, on the other hand, saw the invasion as a reason to slow things down.

${ }^{397}$ LAC, RG 25, Vol. 8907, File 20, Part 5. Message (2326), Ignatieff to External Affairs, 22 August 1968; LAC, RG 25, Vol. 8907, File 20, Part 6. "Memorandum for the Minister - Czechoslovakia at the United Nations" [I] from the Under-Secretary of State for External Affairs (initialed "M.C." at end and signed, probably, by W.H. Barton), 23 August 1968 (judging from the letters in the signature, it appears that W.H. Barton of the Department's UN Division initialed it on Cadieux's behalf).

${ }^{398}$ Canadian Press-Reuters, “'Characteristic of propaganda machine': Sharp rejects Soviet charge Ignatieff plotting at UN," The Globe and Mail, 5 September 1968, A4.

399 Ignatieff, Memoirs, 234.

${ }^{400}$ LAC, RG 25, Vol. 8907, File 20, Part 5. Policy Statement Distribution (PST 67) - Czechoslovak Situation, 22 August 1968; UPI-Special, "Prague invasion could affect our NATO policy: Trudeau," Toronto Star, 22 August 1968, C1, C9. 
There was the reality observed in a hand-written note on a Cadieux memorandum that NATO had been "caught napping."401 The Soviets had demonstrated that achieving the element of surprise was still possible on the NATO frontier. This was reason enough, Cadieux argued, to maximize Canada's military presence in Europe while continuing its pursuit of détente. But as Trudeau intimated during his airport repartee with reporters, would Canada's conventional contribution to NATO's forces in Europe really make a difference in an atomic world? Was the "balance" of nuclear deterrents not strong enough $?^{402}$ Cadieux's opinion stood in contrast to Trudeau's sermon that day of a divided world "evolve[ing]" beyond its Cold War animosities ${ }^{403}$ and Sharp's expressed desire on national television to "discard the past, and to move into the modern world." "404

The DEA initially misread the outcome of the crisis. At first it appeared to Cadieux and his officials that Czechoslovakians had won even more than a moral victory over the Soviets: instead of a "pliable puppet regime and a submissive Czechoslovak populace, Moscow must now reckon with a government and party in Prague" now only "strengthened by their success," wrote Cadieux. ${ }^{405}$ If this were true (which it proved to be not), Czechoslovakians could be seen as partners in the pursuit of détente behind the Iron Curtain, without any interference from the West in their Warsaw Pact disputes. This was

401 See LAC, RG 25, Vol. 8907, File 20, Part 5. "Note for Mr. Collins - The Soviet Invasion of Czechoslovakia" from the Under-Secretary of State for External Affairs (typed for M. Cadieux and signed "M.C." at end), 22 August 1968.

${ }^{402}$ LAC, RG 25, Vol. 8907, File 20, Part 5. Policy Statement Distribution (PST 67) - Czechoslovak Situation, 22 August 1968.

${ }^{403}$ LAC, RG 25, Vol. 8907, File 20, Part 5. Policy Statement Distribution (PST 67) - Czechoslovak Situation, 22 August 1968.

${ }^{404}$ LAC, RG 25, Vol. 8908, File 20, Part 11. "Transcript of Interview by the Honourable Mitchell Sharp for CBC News Magazine, September 3, 1968 Concerning Czechoslovakia,” 3 September 1968.

405 LAC, RG 25, Vol. 8907, File 20, Part 8. "Memorandum for the Minister - Soviet Occupation of Czechoslovakia: Motives and Timing," from the Under-Secretary of State for External Affairs (stamped M. Cadieux at end), 27 August 1968. 
one more reason, aside from a fear of upsetting the Soviets even more, for Canada not to be seen to interfere in Czechoslovakia's affairs.

Officials at External Affairs had underestimated just how much of a reversal for Czechoslovakia the invasion had been. While they remained wary of rattling the Soviet cage any further than they already had at the UN, they advised Sharp, at least in the shorter term, to stake out a firmer position against Soviet aggression than he was prepared to take. Instead, he declared that he was ready to "proceed on the basis not of despair, but of hope" 406 - a mere two weeks after the Soviet Union had invaded Czechoslovakia. Canada’s Opposition, on both the right and the left, as well as the media, continued to be shocked by the government's tone. Where was the "condemnation" of the Soviets in the Throne Speech, asked the NDP's David Lewis. ${ }^{407}$

Perhaps the filmmakers at the NFB understood the stakes better. They found their own way to help Czechoslovakia. The DEA helped them produce a film using smuggled footage of the occupation, but even that required a cover story. Similarly, agents of the RCMP maintained their vigil against communism on the home front - surveillance rooted in an ideological fear that still prevailed inside the Canadian government.

This was a time of international crisis that at the very least called for a well-briefed executive branch. Yet one week into the crisis, Trudeau still questioned the usefulness of Canada's Department of External Affairs. Despite its share of misjudgments, the DEA demonstrated its usefulness from the start of the crisis. After Sharp's bungling of the government's initial reaction to the invasion, the DEA crafted a statement which the

\footnotetext{
${ }^{406}$ LAC, RG 25, Vol. 8908, File 20, Part 11. "Transcript of Interview by the Honourable Mitchell Sharp for CBC News Magazine, September 3, 1968 Concerning Czechoslovakia,” 3 September 1968.

${ }^{407}$ Ottawa Bureau, 'Long-winded alibi': 'An unswinging speech' Trudeau's great expectations land with thud, Opposition spokesmen say," The Globe and Mail, 13 September 1968, A8.
} 
Minister discussed with Trudeau and presented to cabinet for approval the next morning. Then he veered off script. The statement that the DEA had provided made no mention of Canada accepting anyone from Czechoslovakia who wanted to "get out." no reference to refugees at all. ${ }^{409}$

The Czech crisis would go on to demonstrate the clear divide between those in charge of Canada's international relations and those seeking to strengthen its talent pool. Of all the differences in approach to international relations made evident by Canada's crisis response, this was the most significant. It was also the most avoidable. Despite the UnderSecretary's repeated calls for caution - his internal warnings about the potential "decapitation" of Czechoslovakian society ${ }^{410}$ and further harm it might cause to relations with the Soviets ${ }^{411}$ - the Trudeau cabinet approved a refugee programme that, from the beginning, served Canada's future at Czechoslovakia’s expense.

It was avoidable not only because Cadieux and others warned against it, but because of how it began: an improvised choice of words by Minister Sharp two days into the crisis. On 22 August, Czechoslovakia was under occupation and the situation was uncertain. While it ultimately became clear that most Czechoslovakian migrants were not desperate refugees fleeing an oppressive turn in their country's political situation, this was not evident to officials in Ottawa the day after the invasion. Sharp told a group of Czechoslovakian-Canadians that Canada "would give haven to any citizens of

${ }^{408}$ Ottawa Bureau, "Sharp promises Czech refugees ready welcome," The Globe and Mail, 23 August 1968, A9; Ottawa Bureau, "Canada will welcome Czech refugees: Sharp," Toronto Star, 22 August 1968, C1.

${ }^{409}$ LAC, RG 25, Vol. 8907, File 20, Part 4. "Statement by the Secretary of State for External Affairs"; LAC, RG 2, Series A-5-a, Vol.6338. Cabinet minutes, 21 August 1968. 5.

${ }^{410}$ LAC, RG 25, Vol. 8907, File 20, Part 3. "Memorandum for the Minister - Czechoslovak Refugees," from the Under-Secretary of State for External Affairs (initialed "M.C." at end), 9 September 1968.

${ }^{411}$ LAC, RG 25, Vol. 8908, File 20, Part 12. Halstead to Brown, concerning "Czechoslovak Refugees," 5 September 1968 . 
Czechoslovakia who want to get out." ${ }^{412}$ There was a difference, however, between needing to leave Czechoslovakia and wanting to come to Canada. In effect, Sharp turned those desiring the latter into refugees with a hastily-made promise.

Canada already had a clear and standard procedure for relaxing the selection criteria for immigration once someone under such circumstances was determined to be a refugee. Even Trudeau had observed to reporters how hospitable Canada had always been to "real political refugees." ${ }^{413}$ In this case, as Couillard told MacEachern on 30 August, that policy defined a refugee as "a person who, because of fear of political persecution, left a country of Eastern Europe. ${ }^{״ 14}$ Had Sharp not phrased his well-meaning pledge the way he did, Canada's existing refugee policy as it stood would have sufficed: only those who legitimately feared political persecution would have had their entry into Canada fasttracked. What Sharp had promised went beyond what could be accommodated by this existing policy. It therefore had to be adjusted.

Sharp's promise became the guideline. Regardless if they feared "political persecution," and wherever they happened to be at the time of the invasion, if a Czechoslovakian wished to leave, the relaxed policy for refugees would apply. This definition provided visa officers in Prague, Vienna, Belgrade, and anywhere else in the world where Czechoslovakians were applying, the justification to accept them as refugees. Manpower, not humanitarianism, had been a preoccupation of officials in Belgrade,

${ }^{412}$ Ottawa Bureau, "Sharp promises Czech refugees ready welcome," The Globe and Mail, 23 August 1968, A9; Ottawa Bureau, "Canada will welcome Czech refugees: Sharp," Toronto Star, 22 August 1968, C1.

${ }^{413}$ LAC, RG 25, Vol. 8907, File 20, Part 5. Policy Statement Distribution (PST 67) - Czechoslovak Situation, 22 August 1968.

${ }^{414}$ See LAC, RG 76, Vol. 987, File IM 5782-1, Part 1. Memorandum to the Minister "Re: Czechoslovak Crisis - Possibility of Refugee Movement" from Deputy Minister of DMI Couillard, 30 August 1968; Memorandum to the Minister "Re: Czechoslovak Refugees" from Deputy Minister of DMI Couillard, 3 September 1968. 
Vienna, and Geneva from the start. They knew very early on that the Czechoslovakians knocking on Canada's doors were a highly qualified sample of Czechoslovakian society. Conveniently, economically attractive applicants could now meet Canada's less stringent entry requirements for refugees as easily as those with legitimate fears for their life.

This was a consequence, rather than the intention, of the original humanitarian promise. The motive of Sharp's pledge was not economic, but political, made in the course of a meeting with people clearly dissatisfied with the government's initial reaction to the crisis. The Trudeau government did not immediately eye the Soviet invasion of Czechoslovakia as an opportunity to exploit the country for its well-skilled labour. That benefit was realized soon after. Indeed, the wider context of Sharp's initial pledge tempers somewhat the Laura Madokoro thesis that the government purposefully "manipulated" the definition of refugee during the crisis in order to capitalize on the benefits that migrants from Czechoslovakia would bring to Canada. ${ }^{415}$ It did so, initially, so that its refugee policy could be applied to everyone, inside or outside of Czechoslovakia, who fell under the umbrella of Sharp's promise.

This last difference between Cadieux's approach and that now being pursued by cabinet only grew from there, and it went beyond just Cadieux's immediate circle. While the Canadian government realized the potential economic benefits inherent in the policy change only after Sharp had made the initial commitment, the decision to proceed as it did had turned into an economic one by the time it had reached the cabinet. A quick decision on the programme, MacEachen told his colleagues, would enable Canadian officials "to select the best of the refugees who wished to come to Canada."416

415 See Madokoro, "Good," 161-162; 166.

${ }^{416}$ LAC, RG 2, Series A-5-a, Vol. 6338. Cabinet minutes, 10 September 1968. 4-5. 
Canada's refugee initiative was, within days of its inception, perceived as a recruitment effort. Cadieux had warned against this from the start, and then was left to defend it internationally. Other officials both in the DEA and the DMI were as displeased as he was. From Vienna, Ambassador McCordick compared the talent team that cabinet had approved sending there to "ambulance chasers." 417 His Austrian counterpart had a similar reaction in Ottawa. Nonetheless, efforts to court well-qualified applicants already outside of Czechoslovakia continued. Additional assistance was being provided to individuals or groups at home that saw the invasion as an opportunity either to lure, or expedite the migration, of prospective Czechoslovakians to Canada. By October, the Opposition was challenging the government on the issue. In response, it mounted a "moral" defence. $^{418}$ This same morality did not apply, however, to Czech Nationals who happened to be identified as "gypsies." 419

What officials feared at the beginning of the crisis never materialized. As Couillard told MacEachen in October, "while Canadians believe there is a refugee crisis, in fact few refugees themselves behave as though there was any urgency in fleeing their country." 420 The fears of political persecution which had prompted Canada's humanitarian response had not been realized. Yet as Cadieux had warned, Canada's response had enabled

${ }^{417}$ LAC, RG 25, Vol. 8908, File 20, Part 13. Message (905), Canadian Embassy, Vienna, to External Affairs, 19 September 1968.

${ }^{418}$ LAC, RG 76, Vol. 987, File IM 5782-1, Part 6. Memorandum to the Minister, DMI, 11 October 1968; Memorandum to the Minister regarding "Czech Dentists" signed (stamped) by R.B. Curry for the Deputy Minister, 15 October 1968; Memorandum to the Minister regarding "Dentists from Czechoslovakia" signed (stamped),by R.B. Curry for the Deputy Minister, 16 October 1968.

${ }^{419}$ LAC, RG 76, Vol.1401, File IM 5782-1, Part 8. Memorandum regarding "Gypsies - applying in Vienna as Czechoslovak Refugees" from Director, Foreign Branch to Assistant Deputy Minister (Immigration), 29 October 1968.

${ }^{420}$ LAC, RG 76, Vol.1402, File IM 5782-1, Part 3. Memorandum to the Minister regarding "Czechoslovak Refugees” from Deputy Minister L.E. Couillard, 15 October 1968. 
thousands of well-qualified Czechoslovakians to leave their country as refugees. The Soviets had pushed them. Canada had pulled them. Both actions hurt Czechoslovakia.

In the final assessment, it is difficult to overlook Canada's own pursuit of national interest during what was, after all, Czechoslovakia's time of need. This was part of the delusive quality that so characterized Canada's response - such emphasis on futile, if not vain, UN drama; such a failure to grasp how calamitous the invasion was for liberal dreams in Czechoslovakia, such tiptoeing around Soviet feelings in pursuit of what was surely a now more elusive goal of détente; and a new prime minister so dismissive of his country's foreign service, even at a time of international crisis. An inexperienced government's first foray into East-West international relations was marked by a failure to heed the best advice it received from its top advisors. Czechoslovakia paid the price. 


\section{Bibliography}

\section{Primary Sources}

\section{A. Government of Canada Documents}

Canadian Representatives Abroad [Directory], Department of External Affairs, December, 1968. Global Affairs Canada Digital Library, Jules Léger Library, Global Affairs Canada. http://www.gac.canadiana.ca

Canadian Representatives Abroad and Representatives of Other Countries in Canada [Directory], Department of External Affairs, February, 1967. Global Affairs Canada Digital Library, Jules Léger Library, Global Affairs Canada. $<$ http://www.gac.canadiana.ca $>$

Department of External Affairs Telephone Directory, 1 August 1968. Jules Léger Library, Global Affairs Canada, Ottawa.

Library and Archives Canada (LAC), Department of External Affairs fonds, (textual record), RG 25, "Czech-1-3-USSR, Czech-political affairs," August-October, 1968, Volume 8907, File 20, Parts 3-10; Volume 8908, File 20, Parts 11-18.

Library and Archives Canada (LAC), Department of External Affairs fonds, (textual record), RG 25-A-3-c, "Political Affairs-Policy and Background-Canada External Policy and Relations-Special Task Force on Europe," 1968, Volume 8837, File 20-1-2-Stafeur-9.

Library and Archives Canada (LAC), Department of Manpower and Immigration fonds, (textual record), RG 76, "Refugees-Czechoslovak Movement,"1968-1969, Volume 987, File IM 5782-1, File Parts 1,2,6; Volume 1402, File IM 5782-1, File Parts 3,4,11,12; Volume 1401, File IM 5782-1, File Parts 5,7,8,9,10.

Library and Archives Canada (LAC), Department of National Defence fonds, (textual record), RG 24-B-2, "United Nations-Czechoslovakia-Crisis," 21 August 21- 8 November 1968, Volume 21594, File S-2-5080-7.

Library and Archives Canada (LAC), Privy Council Office fonds (textual record), RG 2, "Cabinet Conclusions" 1944-1976, Series A-5-a, volume 6338, Access code 90. Cabinet minutes, 21 August - 10 September 1968.

Library and Archives Canada (LAC), Privy Council Office fonds, RG 2-A-1-a, Volume 2380, PC 1967-1616, "Immigration Act, Immigration Regulations, Part 1, Amended, Schedule A: Norms of Assessment of Independent Applicants," 16 August 16, 1967. 


\section{B. Newspaper Databases}

The articles listed below were accessed through the following databases online:

The Globe and Mail: Canadian Heritage from 1844. ProQuest Historical Newspapers. Carleton University. 2013-2018. <http://proxy.library.carleton.ca>

Toronto Star: Pages from the Past (1894-2014). ProQuest Historical Newspapers. Carleton University. 2013-2018. <http://proxy.library.carleton.ca $>$

i. Newspaper Articles

“A black night for Czechoslovakia.” Toronto Star, 31 August 1968, A6.

“A certain urgency, please.” The Globe and Mail, 31 August 1968, A6.

"A rape permitted." The Globe and Mail, 22 August 1968, A6.

Allen, Greg. "Dubcek: His choices ran out at last." Toronto Star, 22 August 1968, A7.

Anderson, Raymond. "Czechs face new attack from Soviet." The Globe and Mail, 20 August 1968, A8.

AP. "Soviet diplomat tells Johnson." The Globe and Mail, 21 August 1968, A1.

AP and New York Times. "Hope invaders will begin withdrawal soon: Prague House acts to slow liberalization, reimposes censorship." The Globe and Mail, 14 September 1968, A1.

AP, New York Times, and Reuters. "Go to work, people told." The Globe and Mail, 21 August 1968, A1-2.

AP-Reuters. "Czechoslovak border area: New Red manoeuvres planned." The Globe and Mail, 12 August 1968, A1.

AP-Reuters. "Soviet troops seize reform leaders, fire on Czechs in Prague streets; Didn't ask Reds, Prague tells UN.” The Globe and Mail, 22 August 1968, A1.

“Apologetic Czech at UN says: Ivan, go home.” Toronto Star, 26 August 1968. A4.

Bain, George. "Stanfenbaker or Diefenfield." The Globe and Mail, 20 August 1968, A6.

Buist, Vincent. "Gunfire, phone wires ripped out and a cold meal: How Russian soldiers hustled a handcuffed Dubcek out of Prague." The Globe and Mail, 29 August 1968, A1. 
Camp, Dalton. "Hobbled by ourselves." The Globe and Mail, 31 August 1968, A9.

"Canada seeks Czech brains in Vienna." Toronto Star, 18 September 1968, A83.

Canadian Press (Photo). "Outside Russian Embassy.” Toronto Star, 23 August 1968, A9.

Canadian Press. "Czech ‘cream' allegation is denied.” The Globe and Mail, 20 September 1968, A4.

Canadian Press. "PM climbs mountain near Jasper." The Globe and Mail, 1 September 1968, A8.

Canadian Press. "PM holidays at Jasper." The Globe and Mail, 31 August 1968, A4.

Canadian Press. "PM declares Canada open to refugees." The Globe and Mail, 31 August 1968, A4.

Canadian Press. "Sharp Firm: Chinese objections rejected." The Globe and Mail, 13 August 1968, A25.

Canadian Press. "Sharp sees Czech rush to seek Canada home." The Globe and Mail, 2 September 1968, A11.

Canadian Press. "Soviet Embassy occupants silent as Czechoslovaks demonstrate." The Globe and Mail, 23 August 1968, A9.

Canadian Press. "Trudeau has two choices in action on Czech crisis." Toronto Star, 22 August 1968, A1.

Canadian Press-AP. "Just what was said: By the Russians." The Globe and Mail, 28 August 1968, A4.

Canadian Press-Reuters. "“Characteristic of propaganda machine': Sharp rejects Soviet charge Ignatieff plotting at UN.” The Globe and Mail, 5 September 1968, A4.

“Carbon Copy PM.” The Globe and Mail, 5 September 1968, A6.

"Come home, Czech leaders urge those who fled." Toronto Star, 11 September 1968, A1; A4.

Cooper, Carol. "Grant McLean 1921-2002: He filmed the difficult, riled the powerful." The Globe and Mail, 11 January 2003, pg F8.

“Czechoslovakia: Chains or qualified freedom?” Toronto Star, 28 August 1968, A6.

“Czechs' 'best brains' told to flee.” Toronto Star, 30 August 1968. A1; A4. 
Davis, E.N. "Criticism of Soviet hurt sales." The Globe and Mail, 12 September 1968, B5.

Dzeguze, Kaspars. "Movies: A Document of Contemporary Disaster." The Globe and Mail, 16 May 1969, 13.

"Dubcek reported free, may get his job back; Czechs say he's on way to Prague." Toronto Star, 24 August 1968, A1, A4.

Enright, Michael. "U.S. urges Russians to pull out; has no plans for military intervention." The Globe and Mail, 22 August 1968, A8.

“Even a superpower can be embarrassed.” Toronto Star. 23 August 1968, A6.

"Four plays, four stumbles in foreign policy." Toronto Star, 21 September 1968, A6.

"Fell in bath, Dubcek says of bandage." The Globe and Mail, 30 August 1968, A2.

Forrest, Rev. A.C. "55 Czechoslovak refugees on flight bound for Montreal.” Toronto Star, 11 September 1968, C1; C4.

Frye, William. "Czech crisis may EASE the Cold War." Toronto Star, 31 August 1968, A11.

Gayn, Mark. "Pro-Soviet regime expected within 48 hours." Toronto Star, 21 August 1968, A8.

Hazlitt, Tom. "No word from Prague: Czechs in Ottawa just sit and wait." Toronto Star, 23 August 1968, pg 9; B9.

"Here is the text of the Governor-General's Throne Speech." Toronto Star, 12 September 1968, D9.

Hoffman, Fred. "Spymasters warned LBJ of Soviet invasion." Toronto Star, 23 August 1968. A7.

"It's a time of frustration for the West." Toronto Star, 24 August 1968, A6.

Jones, Frank. ““A whole generation will die,' Czech says.” Toronto Star, 21 August 1968, C1.

Jones, Frank. “Czech envoys listened in underwear.” Toronto Star, 21 August 1968, C4.

Lennon, Frank. (Photo). “2 Czechs enter Canada's gate.” Toronto Star, 16 September 1968. A1. 
"Let's not go back to the cold war." Toronto Star, 22 August 1968, A6.

"Metro's Czechoslovak community plans convoy to take plea to PM." The Globe and Mail, 22 August 1968, 8.

New York Times Service. “'Anti-socialist forces:' Prague liberals losing control, Pravda claims." The Globe and Mail, 19 August 1968, A1.

New York Times and AP. "Talks ended, Tass reports. Dubcek to retain post, Czechs in Moscow say." The Globe and Mail, 27 August 1968, A1.

New York Times and Reuters. “'We've been sold out,' Czechs cry as Dubcek makes plea for support: Press censorship re-imposed today." The Globe and Mail, 28 August 1968. A1.

New York Times Service. "Soviets force Dubcek ouster." The Globe and Mail, 18 April 1969, A1.

Ottawa Bureau. "Allies to avoid return to mood of Cold War." The Globe and Mail, 11 September 1968, A25.

Ottawa Bureau. "As if they had never been away." The Globe and Mail, 14 September 1968. A3.

Ottawa Bureau. "Canada will welcome Czech refugees: Sharp." Toronto Star, 22 August $1968, \mathrm{C} 1$.

Ottawa Bureau. "Crisis brings Trudeau home.” Toronto Star, 21 August 1968, A1.

Ottawa Bureau. "Dispatch of UN peacekeeping force urged." The Globe and Mail, 22 August 1968, A9.

Ottawa Bureau. "Invasion disappointing to Sharp, "no immediate threat to peace." The Globe and Mail, 21 August 1968, A1.

Ottawa Bureau. "It'll set our relations back years says Sharp of Soviet invasion." Toronto Star, August 21, 1968, A1.

Ottawa Bureau. 'Long-winded alibi': 'An unswinging speech' Trudeau's great expectations land with thud, Opposition spokesmen say." The Globe and Mail, 13 September 1968, A8.

Ottawa Bureau. "Motion on Czechs to stay on UN agenda." The Globe and Mail, 28 August 1968, A4. 
Ottawa Bureau. "PM thinking of marriage - but to which girl?" Toronto Star, 22 August 1968, C9.

Ottawa Bureau. "Sharp promises Czech refugees ready welcome." The Globe and Mail, 23 August 1968. A9.

Ottawa Bureau. "Trudeau cuts holiday short but faces slow ride home." Toronto Star, 21 August 1968. pg C1.

Ottawa Bureau. "Trudeau sneaks out of Ottawa, flies to 'secret' holiday in Spain." The Globe and Mail, 17 August 1968, A1.

Ottawa Bureau. "\$2 million fund set up to fly in 1,000 Czechs." The Globe and Mail, 12 September 1968. A8.

Quebec Bureau. "Stanfield cites Red invasion in seeking Parliament's recall." The Globe and Mail, 23 August 1968, A8.

Reguly, Robert. "Canada demands UN rescue deposed Czechs." Toronto Star. 23 August 1968. A1.

Reguly, Robert. "Russia assures Canada Czech crisis over soon.” Toronto Star, 24 August 1968, A4.

Reguly, Robert. “'Soviets out to kill UN Czech debate'.” Toronto Star, 22 August 1968. C1; C9.

Reguly, Robert. "Western countries shocked but they plan no intervention." Toronto Star, 21 August 1968, A1, A4.

Reuters. "20-minute briefing each: Rush of Czech refugees handled in crash program." The Globe and Mail, 16 September 1968, A17.

Reuters. “... and by Alexander Dubcek.” The Globe and Mail. 28 August 1968, A4.

Reuters. “...by Ludvik Svoboda.” The Globe and Mail, 28 August 1968, A4.

Reuters. "Czechs plan UN boycott during crisis." The Globe and Mail, 27 August 1968, A1.

Reuters. "Elusive PM leaves resort for Madrid." The Globe and Mail, 21 August 1968, A4.

Reuters. "Invited, Moscow says; no warning: Czech." The Globe and Mail, 21 August 1968, A1. 
Reuters. "Prague Trip still on, U Thant silent on border move." The Globe and Mail, 21 August 1968, A2.

Salwyn, Andrew. "Czechs arrive in Montreal; 'We all love Dubcek'." Toronto Star, 9 September 1968, A28.

Seale, Lewis. "Cabinet meets." The Globe and Mail, 24 August 1968, 4.

Seale, Lewis. "Canada may stall any plans to cut troops." The Globe and Mail, 23 August 1968, A8.

"Self-interest comes first." The Globe and Mail, 27 August 1968, A6.

“Soviet troops get tougher; Czechs hold one-hour strike." Toronto Star, 23 August 1968, A1.

"Stations give up." The Globe and Mail, 30 August 1968, A1.

Szulo, Tad and Clyde Farnsworth. "Seven days that shook Czechoslovakia: quislings' failure and secret congress." The Globe and Mail, 4 September 1968. A3.

The Globe and Mail. Front page headlines. The Globe and Mail, 21 August 1968, A1.

“The long ago." The Globe and Mail, 14 August 1968, A6.

“The Rape of a Nation: Stalin's spirit breathes again.” Toronto Star, 21 August 1968, A6.

“The Red army was Russia’s final argument.” Toronto Star, 21 August 1968, A9.

The Times of London, "Internal issue at present, NATO states." The Globe and Mail, 22 August 1968, A9.

"Their arrival honors us." The Globe and Mail, 17 September 1968. A6.

“Threat of Soviet veto hangs over UN." Toronto Star, 22 August 1968. A1; A9.

UPI-Special. "Czechs at UN don't want to rock Kremlin boat." Toronto Star, 26 August 1968, A1; A4.

UPI-Special. "Prague invasion could affect our NATO policy: Trudeau." Toronto Star, 22 August 1968, C1; C9.

Westell, Anthony. "Censure filibuster mounted." The Globe and Mail, 23 August 1968, A1. 
Westell, Anthony. "Ottawa standing idle on Biafra: Stanfield." The Globe and Mail, 14 September 1968, A1.

Westell, Anthony. "Security Council adopts wait-and-watch position." The Globe and Mail, 24 August 1968, A1.

Westell, Anthony. "Sharp hands Red diplomats Cabinet statement protesting against invasion." The Globe and Mail, 22 August 1968, A9.

Westell, Anthony. "Throne Speech ignores Queen: Backlog of 47 bills gets House priority." The Globe and Mail, 13 September 1968. A1.

Westell, Anthony. "United Nations: The troubles that plague world prosecutors." The Globe and Mail, 24 August 1968, A9.

Westell, Anthony. "West to chart course on Prague crisis." The Globe and Mail, 26 August 1968, A8.

White, William. "Courage of Czech nation shines in Red nightmare." Toronto Star, 28 August 1968, A8.

"World Reaction." The Globe and Mail, 22 August 1968, A1.

Young, Scott. "Times when some words are not enough to describe one's feelings." The Globe and Mail, 22 August 1968, A7.

“203 Czechs arrive here on 'freedom airlift."” Toronto Star, 16 September 1968, A23.

"4,000 join forces outside City Hall to demand Russian quit homelands." The Globe and Mail, 30 August 1968, A5.

“10,000 Metro Czechs await news of relatives.” Toronto Star, 21 August 211968, A69.

\section{Secondary Sources}

A. Books

Anderson, Benedict. Imagined Communities: Reflections on the Origins and Spread of Nationalism. Brooklyn: Verso, 1983.

Ball, George. The Past Has Another Pattern. New York: W.W. Norton and Company, 1982.

Bothwell, Robert. Alliance and Illusion: Canada and the World, 1945-1984. Vancouver: UBC Press, 2007. 
Bothwell, Robert and J.L. Granatstein. Pirouette: Pierre Trudeau and Canadian Foreign Policy. Toronto: University of Toronto Press, 1990.

Calleo, David. Beyond American Hegemony: The Future of the Western Alliance. New York: The Twentieth Century Fund, Basic Books, Inc., Publishers, 1987.

Cox, Robert. "Gramsci, Hegemony and International Relations: An Essay in Method. In Stephen Gill (ed.), Gramsci, Historical Materialism and International Relations. Cambridge: Cambridge University Press, 1993.

Dobell, Peter. Canada's Search for New Roles: Foreign Policy in the Trudeau Era. London: Oxford University Press, 1972.

English, John. Citizen of the World: The Life of Pierre Elliot Trudeau, Volume One, 19191968. Toronto: Vintage Canada, 2006.

English, John. Just Watch Me: The Life of Pierre Elliot Trudeau, Volume Two, 1968-2000. Toronto: Vintage Canada, 2009.

English, John. The Worldly Years: The Life of Lester Pearson, Volume II: 1949-1972. Toronto: Alfred A. Knopf, 1992.

Ford, Robert. Our Man in Moscow: A Diplomat's reflections on the Soviet Union. Toronto: University of Toronto Press, 1989.

Foucault, Michel. Discipline and Punish: The Birth of the Prison. New York: Vantage Books, 1977.

Foucault, Michel. Security, Territory, Population. Lectures at the Collège de France, 1977-1978. Edited by Michel Senellart. Translated by Graham Burchell. New York: Palgrave Macmillan, 2007.

Gaddis, John Lewis. Strategies of Containment: A Critical Appraisal of Postwar American National Security Policy. New York: Oxford University Press, 1982.

Gaddis, John Lewis. The Long Peace: Inquiries into the History of the Cold War. New York: Oxford University Press, 1987.

Granatstein, J.L. "External Affairs and Defence." In Canadian Annual Review, 1968, edited by John Saywell, 217-282. Toronto: University of Toronto Press, 1969.

Gwyn, Richard. The Northern Magus: Pierre Trudeau and Canadians. Toronto: McClelland and Stewart Inc., 1980.

Harari, Yuval Noah. Sapiens: A Brief History of Humankind. Toronto: McClelland and Stewart Inc., 2014.

Head, Ivan and Pierre Trudeau. The Canadian Way: Shaping Canada's Foreign Policy, 1968-1984. Toronto: McClelland and Stewart Inc., 1995. 
Hawkins, Freda. Canada and Immigration: Public Policy and Public Concern. Montreal and Kingston: McGill-Queen's University Press, 1988.

Hilliker, John and Donald Barry. Canada's Department of External Affairs, Volume 2: Coming of Age, 1946-1968. Montreal and Kingston: McGill-Queen's University Press, 1995.

Hilliker, John, Greg Donaghy, and Mary Halloran. Canada's Department of External Affairs, Volume 3: Innovation and Adaptation, 1968-1984. Toronto: University of Toronto Press, 2017.

Hillmer, Norman. "Peacekeeping: The Inevitability of Canada's Role," in War in the Twentieth Century: Reflections at Century's End, edited by Michael A. Hennessy and B.J.C. McKercher, 145-165. Westport, Connecticut and London: Praeger, 2003.

Hillmer, Norman and Adam Chapnick. "Introduction: An Abundance of Nationalisms" in Canadas of the Mind: The Making and Unmaking of Canadian Nationalisms in the Twentieth Century, edited by Norman Hillmer and Adam Chapnick, 3-14. Montreal and Kingston: McGill-Queen's University Press, 2007.

Hillmer, Norman and J.L. Granatstein. Empire to Umpire: Canada and the World into the Twenty-First Century. Toronto: Thomson, 2008.

Hillmer, Norman and J.L. Granatstein. For Better or For Worse: Canada and the United States into the Twenty-First Century. Toronto: Thomson, 2007.

Hillmer, Norman and Garth Stevenson. "Forward" in A Foremost Nation: Canadian Foreign Policy and A Changing World, edited by Norman Hillmer and Garth Stevenson, 1-2. Toronto: McClelland and Stewart, 1977.

Igartua, José. The Other Quiet Revolution: National Identities in English Canada, 194571. Vancouver: UBC Press, 2006.

Ignatieff, George. The Memoirs of George Ignatieff: The Making of a Peacemonger. Toronto: University of Toronto Press, 1985.

Johnston, Andrew. Hegemony and Culture in the Origins of NATO Nuclear First-use. New York: Palgrave Macmillan, 2005.

Kirton, John. Canadian Foreign Policy in a Changing World. Toronto: Thomson Nelson, 2007.

Laclau, Ernesto and Mouffe, Chantal. Hegemony and Socialist Strategy. London: Verso, 1985. 
Mackenzie, Hector. "Canada's Nationalist Internationalism: From the League of Nations to the United Nations" in Canadas of the Mind: The Making and Unmaking of Canadian Nationalisms in the Twentieth Century, edited by Norman Hillmer and Adam Chapnick, 89-109. Montreal and Kingston: McGill-Queen's University Press, 2007.

Page, Donald. "Canada and European Détente," in A Foremost Nation: Canadian Foreign Policy and A Changing World, edited by Norman Hillmer and Garth Stevenson, 37-62. Toronto: McClelland and Stewart, 1977.

Sharp, Mitchell. Which Reminds Me...A Memoir. Toronto: University of Toronto Press, 1994.

Stevens, Geoffrey. Stanfield. Toronto: McClelland and Stewart Limited, 1973.

Stevenson, Garth. "Canada in the United Nations" in A Foremost Nation: Canadian Foreign Policy and A Changing World, edited by Norman Hillmer and Garth Stevenson, 150-177. Toronto: McClelland and Stewart, 1977.

Thordarson, Bruce. Trudeau and Foreign Policy: A Study in Decision-making. Toronto: Oxford University Press, 1972.

Westell, Anthony. Paradox: Trudeau as Prime Minister. Scarborough: Prentice-Hall of Canada, 1972.

\section{B. Journals and Periodicals}

Beaulne, Maria. "68 Czech Experience." C.I.H.S. Bulletin: The Newsletter of the Canadian Immigration Historical Society, no. 46 (July, 2005). 9-10.

Bissett, Joe. "The Czechoslovakian Refugee Movement, 1968." C.I.H.S. Bulletin: The Newsletter of the Canadian Immigration Historical Society, no. 46 (July, 2005). 1-4.

Bullock, David. "The Czechoslovak Refugee Movement of 1968: Some Personal Reminiscences." C.I.H.S. Bulletin: The Newsletter of the Canadian Immigration Historical Society, no. 46 (July, 2005). 8-9.

Cavanagh-Woods, Joyce. "Vienna." C.I.H.S. Bulletin: The Newsletter of the Canadian Immigration Historical Society, no. 46 (July, 2005): 10-11.

Eayrs, James. "From middle power to foremost power: Defining a new place for Canada in the hierarchy of world power." International Perspectives. Department of External Affairs, Government of Canada. (May-June 1975): 15-24. 
Fortmann, Michel and Martin Larose. "An emerging strategic counterculture? Pierre Trudeau, Canadian intellectuals and the revision of Liberal defence policy concerning NATO (1968-1969).” International Journal 59, Issue 3 (Summer, 2004): 537-556.

Granatstein, J.L. and Norman Hillmer. "Peacekeeping was Pearson's Legacy." Maclean's. July 1, 1999, vol.112, issue 20, pg. 26. Ebsco Canadian Reference Centre $<$ http:web.ebsohost.ca>

Hillmer, Norman. “Are Canadians anti-American?” Policy Options 27, no. 6 (July-August 2006): 63-65.

Kelly, Brendan. "The politician and the civil servant: Pierre Trudeau, Marcel Cadieux, and the Department of External Affairs, 1968-1970." International Journal 2017, vol.72 (I): 5-27.

Madokoro, Laura. "Good Material: Canada and the Prague Spring Refugees." Refuge 26 no. 1 (March, 2009): 161-171.

McGinn, John. "The Politics of Collective Inaction: NATO's Response to the Prague Spring." Journal of Cold War Studies, vol. 1, no. 3 (Fall, 1999): 111-138.

Mesheau, Daryl. Untitled. C.I.H.S. Bulletin: The Newsletter of the Canadian Immigration Historical Society, no. 46 (July, 2005). 12-13.

Mackenzie, Hector. "Golden Decade(s)? Reappraising Canada's International Relations in the 1940s and 1950s." British Journal of Canadian Studies 23, no.2 (July, 2009): 179206.

Molloy, Mike. "Vienna 1968: discovering the world." C.I.H.S. Bulletin: The Newsletter of the Canadian Immigration Historical Society, no. 46 (July, 2005). 13-15.

Zawisza, John. "Processing of the Czechoslovakian Refugee Movement: Vienna, Austria (Sept.-Nov. 1968)." C.I.H.S. Bulletin: The Newsletter of the Canadian Immigration Historical Society, no. 46 (July, 2005). 4-8.

\section{Websites}

"Charles Eustis Bohlen." Office of the Historian. Bureau of Public Affairs. United States Department of State. Accessed 15 August 2018. <http://history.state.gov>

Explore Films. The National Film Board of Canada. Accessed on 29 November 2018. $<$ http://www.nfb.ca $>$ 
Gordon, Stanley. "Scott Young." The Canadian Encyclopedia. Historica Canada. Last modified January 31, 2014. <http://thecanadianencyclopedia.ca/en/article/scottyoung $>$

"Hugh Foot." Britannica Library Reference Center. Encyclopedia Britannica. Ottawa Public Library. City of Ottawa. $<$ http//biblioottawalibrary.ca $>$

"Malik, Jacob A." Korean War Reference Library. Edited by Sonia G. Benson and GerdaAnn Raffaelle. Vol. 2: Biographies. Detroit: UXL. 2002. 96-103. Gale Virtual Reference Library. 2014. Ottawa Public Library. City of Ottawa. 2016. $<$ http//biblioottawalibrary.ca $>$

Mackie, Colin. “A Directory of British Diplomats," Colin Mackie's Website. Last updated 17 July 2018. <www.gulabin.com>

Penner, Norman. "Communist Party of Canada." The Canadian Encyclopedia. Historica Canada. Last modified 30 May 2017. Accessed on 29 August 2018 $<$ http://thecanadianencyclopedia.ca/en/article/communist-party-of-canada $>$.

"Seven Days to Remember (1968)." Explore Film and TV. Films, TV, and People. The British Film Institute. Accessed on 29 November 2018. <http://www.bfi.org.uk>. 